University of South Florida

DIGITAL COMMONS

@ UNIVERSITY OF SOUTH FLORIDA
Digital Commons @ University of

South Florida

6-1-2013

\title{
Integrating Transit with Road Pricing Projects
}

CUTR

Follow this and additional works at: https://digitalcommons.usf.edu/cutr_nctr

\section{Recommended Citation}

"Integrating Transit with Road Pricing Projects," National Center for Transit Research (NCTR) Report No. CUTR-NCTR-RR-2012-03, Center for Urban Transportation Research, University of South Florida, 2013. DOI: https://doi.org/10.5038/CUTR-NCTR-RR-2012-03

Available at: https://scholarcommons.usf.edu/cutr_nctr/104

This Technical Report is brought to you for free and open access by the National Center for Transit Research (NCTR) Archive (2000-2020) at Digital Commons @ University of South Florida. It has been accepted for inclusion in Research Reports by an authorized administrator of Digital Commons @ University of South Florida. For more information, please contact digitalcommons@usf.edu. 


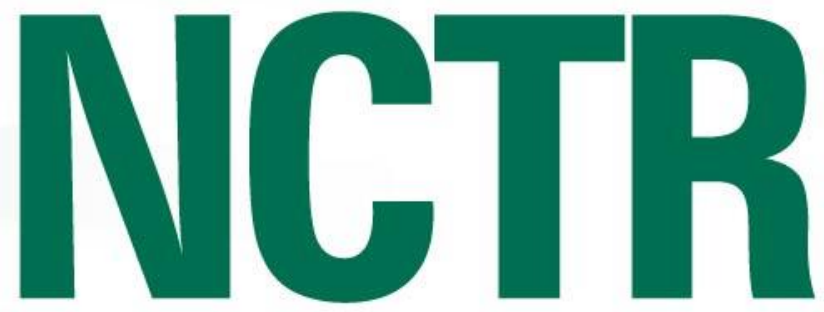

NATIONAL CENTER for TRANSIT RESEARCH

\section{Integrating Transit with Road Pricing Projects}

\section{June 2013}

\section{Final Report}

PROJECT NO.

BDK85 977-43

PREPARED FOR:

Florida Department of Transportation

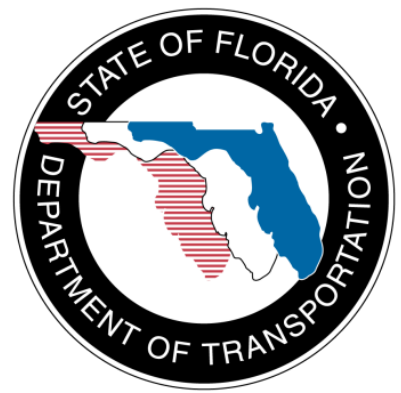




\section{Disclaimer}

The contents of this report reflect the views of the authors, who are responsible for the facts and the accuracy of the information presented herein. This document is disseminated under the sponsorship of the U.S. Department of Transportation University Transportation Centers Program and the Florida Department of Transportation in the interest of information exchange. The U.S. Government and the Florida DOT assume no liability for the contents or use thereof. 


\section{Integrating Transit with Road Pricing Projects}

Prepared for:

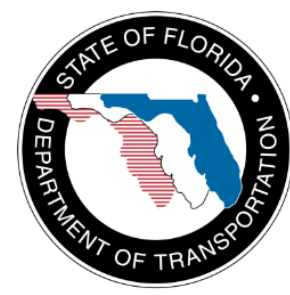

Florida Department of Transportation

Diane Quigley, Project Manager

Prepared by:

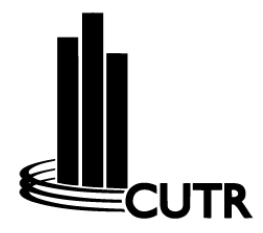

USF Center for Urban Transportation Research

Stephen L. Reich, Associate in Research

Janet L. Davis, Associate in Research

Final Report

June 2013 


\section{Metric Conversion}

\begin{tabular}{|c|c|c|c|c|}
\hline SYMBOL & WHEN YOU KNOW & MULTIPLY BY & TO FIND & SYMBOL \\
\hline \multicolumn{5}{|c|}{ LENGTH } \\
\hline in & inches & 25.4 & millimeters & $\mathrm{mm}$ \\
\hline ft & feet & 0.305 & meters & $\mathrm{m}$ \\
\hline yd & yards & 0.914 & meters & $\mathrm{m}$ \\
\hline mi & miles & 1.61 & kilometers & $\mathrm{km}$ \\
\hline \multicolumn{5}{|c|}{ VOLUME } \\
\hline fl oz & fluid ounces & 29.57 & milliliters & $\mathrm{mL}$ \\
\hline gal & gallons & 3.785 & liters & $\mathrm{L}$ \\
\hline $\mathrm{ft}^{3}$ & cubic feet & 0.028 & cubic meters & $\mathrm{m}^{3}$ \\
\hline$y d^{3}$ & cubic yards & 0.765 & cubic meters & $\mathrm{m}^{3}$ \\
\hline \multicolumn{5}{|c|}{ NOTE: volumes greater than $1000 \mathrm{~L}$ shall be shown in $\mathrm{m}^{3}$} \\
\hline \multicolumn{5}{|c|}{ MASS } \\
\hline $\mathbf{O z}$ & ounces & 28.35 & grams & $g$ \\
\hline lb & pounds & 0.454 & kilograms & $\mathrm{kg}$ \\
\hline $\mathbf{T}$ & short tons (2000 lb) & 0.907 & $\begin{array}{c}\text { megagrams } \\
\text { (or "metric ton") }\end{array}$ & $\mathrm{Mg}(\mathrm{or}$ "t") \\
\hline \multicolumn{5}{|c|}{ TEMPERATURE (exact degrees) } \\
\hline${ }^{\circ} \mathbf{F}$ & Fahrenheit & $\begin{array}{c}5(F-32) / 9 \\
\text { or }(F-32) / 1.8\end{array}$ & Celsius & ${ }^{\circ} \mathrm{C}$ \\
\hline
\end{tabular}




\section{Technical Report Documentation}

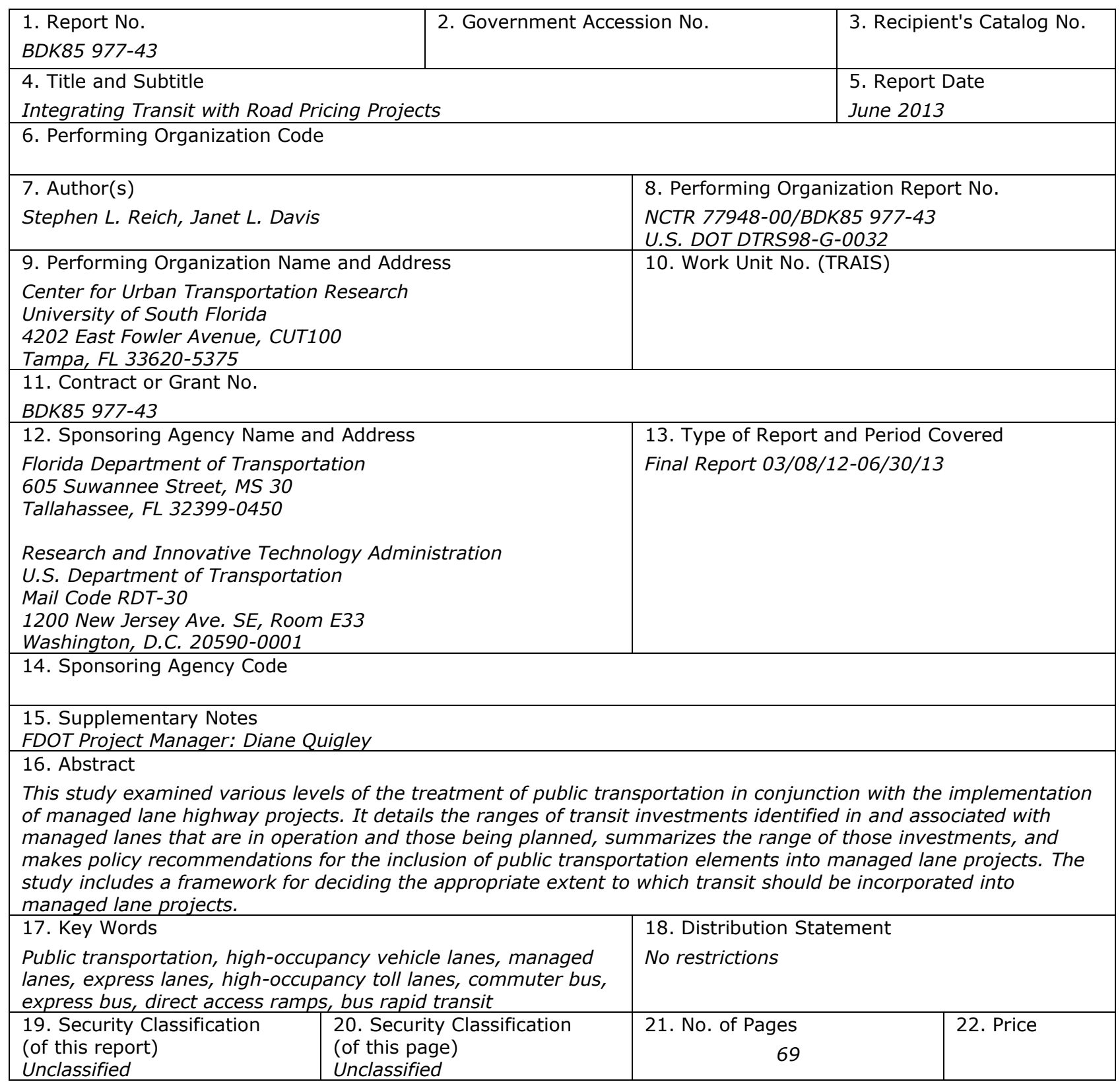




\section{Acknowledgments}

Many people contributed to this research project, and this final report could not have been completed without their assistance and support. The authors would like to specifically express their gratitude to FDOT Project Manager Diane Quigley and representatives from the following organizations who generously contributed their time, expertise, and insight:

Broward County Transit

Georgia Department of Transportation

Georgia Regional Transportation Authority

Florida Department of Transportation

Miami-Dade Transit

San Diego Metropolitan Transit System

San Diego Association of Governments

Washington State Department of Transportation 


\section{Executive Summary}

As traditional transportation funding sources become less sustainable and the demand for mobility increases during the economic recovery, agencies across the United States (U.S.) are looking to the concept of managing highway demand through congestion pricing and maximizing capacity through the active management of the highway network, or employing "managed lanes." The Florida Department of Transportation (FDOT) has embarked on an extensive program to implement express lanes on congested corridors across the state. In August 2011, the secretary of transportation articulated the governor's transportation vision for the future of Florida's state transportation system. As a means to assist in the financing of the facilities, statutory changes were made in the 2012 session of the Florida legislature to assist FDOT in implementing a managed lane program. The law, with certain limitations, allows FDOT to impose tolls on new lanes and on existing bridges in Florida.

To the extent that transit becomes an integral part of a managed lane project that includes tolls and/or pricing the revised statute provides an opportunity for funding transit operating and capital in a new price-managed facility. Policies associated with the integration of public transportation into the planning, design, construction financing, and ongoing operation and maintenance of new managed lanes stem from the motivation of implementing a new or different road pricing strategy. If the principal motivation of an implementing agency is simply to finance the capacity expansion of an otherwise unfunded congested highway through tolling, then the full consideration of integrating transit may not be a priority. If, on the other hand, the implementation of tolls for the first time or a move to dynamic pricing is part of a long-term strategy of managing congestion in a corridor, the integration of transit into the project and program is essential and needs to be considered from project concept through the operation of the facility.

Florida has demonstrated creativity and managed lane success with the implementation of the first phase of the I-95 Express Lanes project in South Florida. FDOT embarked on an ambitious initiative to study, implement, and operate managed lanes as an approach to efficiently and effectively increase mobility. Express lanes have been successfully implemented on I-95 in Miami-Dade County in conjunction with express bus service, and are currently being extended into Broward County to connect with a project on I-595, creating the beginnings of a regional network.

A review of managed lane projects across the U.S. revealed a wide range of treatments of public transportation and its integration into the planning, design, and operation of a managed lane project. Five specific projects were reviewed in more detail because of the transit treatments employed. For these five projects, no tolls were charged for transit vehicles, even in the case of a bridge project where no high-occupancy toll discount is provided (pure express facility). It is fairly common for park-and-ride lot construction and expansion to be included in the construction cost of a managed lane capital project, and in corridors with high transit demand, station funding along with direct access ramps to and from the stations to the managed lanes is not uncommon. While the purchase of new and/or additional rolling stock was a capital cost included in four of the five projects, transit operating subsidies were not being provided in any of the cases. 
The policy motivation for the employment of managed lanes along with the market potential for public transportation are certainly relevant factors in the funding agency's treatment of transit in managed lanes. It also appears that for at least this project set, the level of transit integration into the managed lane project is related to the federal program used to fund a portion of the project. This may be due to the nature of the federal eligibility requirements for programs such as the Urban Partnership Agreement and the Congestion Relief Demonstration. By definition, these programs are targeted at corridors that are in markets with a high transit demand.

Transit treatments for the projects reviewed in this study ranged from exclusive transit access ramps and park-and-ride or bus rapid transit (BRT) stations to express buses using the high-occupancy vehicle (HOV) lane or high-occupancy toll (HOT) lanes. Several managed lane projects included facility design provisions for future rail construction in the corridor. Aggressive public outreach, partnership building, and marketing have been stressed in the success of several of the projects that incorporated transit treatments into a managed lane project. In addition, "off-corridor" design elements have also been implemented as transit components of managed lane projects, including signal prioritization and surface road improvements for easier access to transit stations.

A misconception exists for some that when tolling is implemented, the HOT or express lanes will generate an extraordinary amount of revenue. Depending upon the cost of the project and the plan of finance, it is unlikely that the tolls will cover the capital and operating costs of the physical roadway elements. The use of toll revenue bonds by different entities with different pledges to bondholders can limit the use of funds generated on the facility. While most toll bond trust agreements have strict provisions relating to the toll-free use of facilities, there are typically clauses giving latitude to the rate-maker for exceptions.

When contemplating the incorporation of enhanced public transit into the planning, design, and operation of a managed lane project, arguably the most essential factor for decisionmakers and stakeholders to consider is the strategic objective of the project. If the prime motivation for considering managed lanes is to relieve congestion and provide immediate transportation alternatives within a corridor or across a network, the entire spectrum of actions available to enhance public transportation should be part of all planning and design. Early, clear, and transparent articulation of the strategic goal of a managed lane project will help to provide context for the deliberations over project elements and funding decisions.

Funding for the ongoing operation of enhanced transit service along a price-managed facility should become part of a project's plan of finance, commensurate with the contribution to the project's strategic goals. Minor, low-cost actions can make implementation of a managed lane project more conducive to successful transit service. For example, route alignments for existing commuter bus routes should be examined and modified, if necessary, in order to facilitate vehicle ingress and egress from the express lanes.

Revenue sharing between highway agencies and transit organizations is a possibility that could employ price-managed lane projects that include significant public transportation enhancements. MAP-21 (Moving Ahead for Progress in the 21st Century Act) eligibility 
definitions for transit capital create new opportunities for the financing of BRT projects and for revenue sharing implemented in conjunction with express lane projects.

If a statewide policy on managed lane projects and transit is promulgated, it should be flexible enough with regard to transit to address: the projected market for public transportation in the corridor or on the network; that financial commitments and project components to enhance transit service are commensurate with the market potential in a particular corridor or region; the accommodation of the various financial constraints and requirements of FDOT, Florida's Turnpike Enterprise, local expressway authorities, regional transportation authorities, and transit agencies; and recognition of public transportation's contribution to choice and congestion reduction in the corridor.

Transit agencies with a service area that includes one of the FDOT managed lane studies or projects should undertake a demand forecast for those corridors, if they have not done so recently. This forecast should be at least a sketch planning study that addresses level of demand for express bus service and passenger volumes, and should include the prospect of the introduction of an express or HOT lane or network. Regional Express Bus and/or BRT plans for urbanized regions of Florida should be considered. Current and future transit markets need to be established not only for a single corridor, but there is also value for assessing the potential ridership implications of a network. This plan could then be overlaid on the express lane plan to see what opportunities emerge. This exercise could assist in finding the answers to the appropriate level of transit integration into these projects.

Transit vehicles should not be required to pay any toll on express lanes and particularly on HOT lanes, as buses are the consummate high-occupancy vehicles.

Investments in integrating transit in a managed lane project should be maximized to a level that is commensurate with public transportation's contribution to choice, level of service, and impact on congestion mitigation in a managed lane corridor. Operating costs need to be included as potential managed lane costs. The contributions that public transportation service will make in the corridor are only sustainable long-term with operating funds to support additional or new service. If transit will be relied upon to make continuous contributions to the corridor, these can only be realized with an ongoing funding commitment.

There should be early and wide agreement on the strategic objective of a particular managed lane proposal. Many detailed decisions on a project can be made easier if there is general consensus on a project's main goal. Consideration should be given to adopting a standard approach to assessing the transit ridership forecasts for service provided in conjunction with a managed lane. If similar modeling and forecasting methods were used, FDOT would be in an enhanced position to evaluate transit investment decisions from project to project and across regions of Florida. 


\section{Table of Contents}

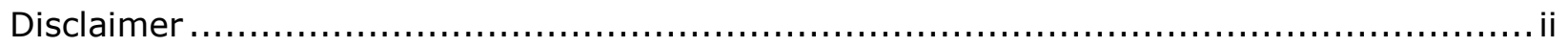

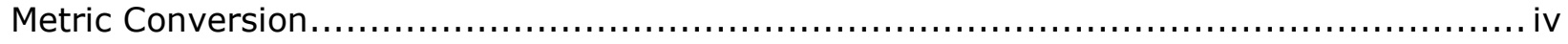

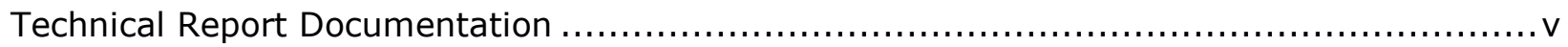

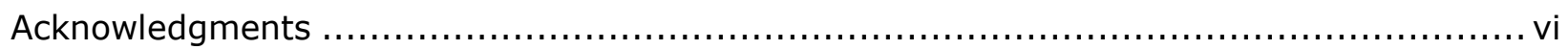

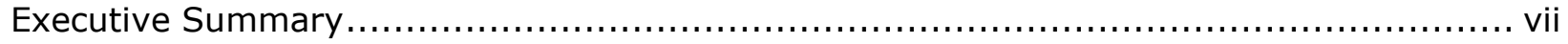

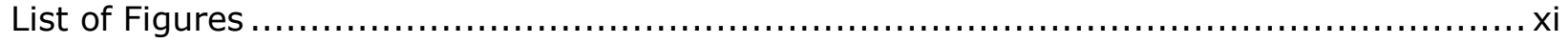

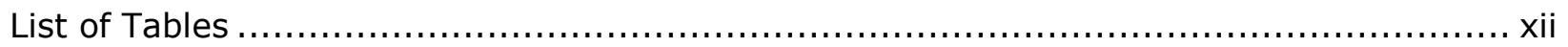

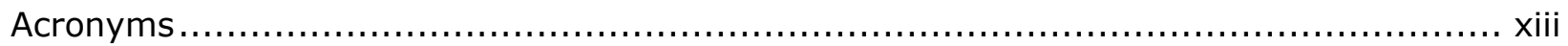

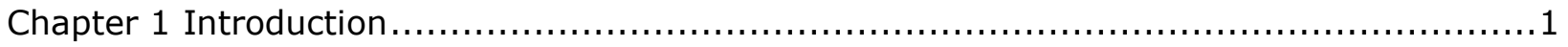

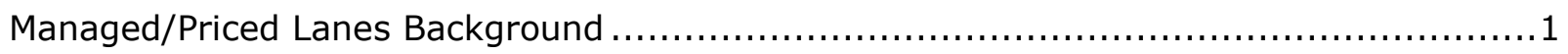

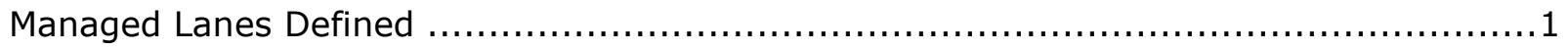

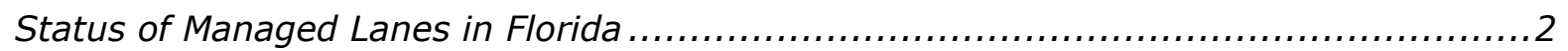

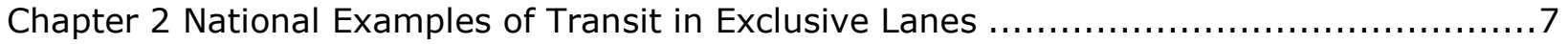

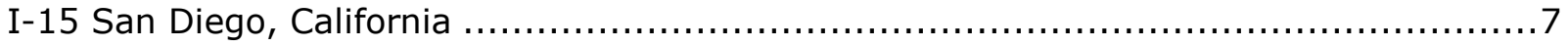

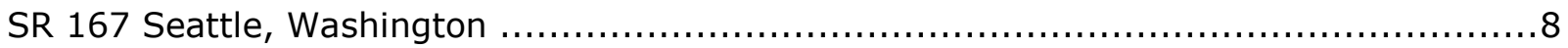

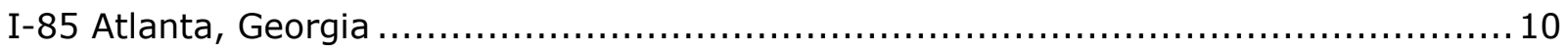

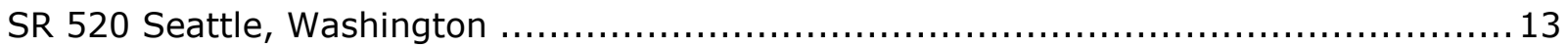

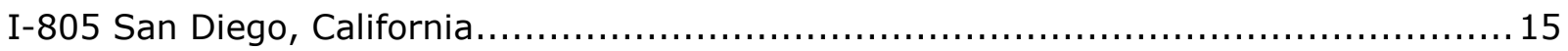

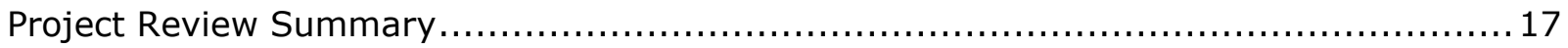

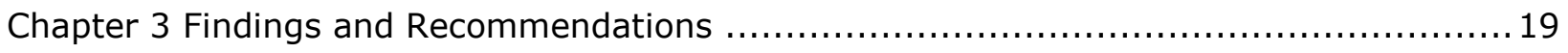

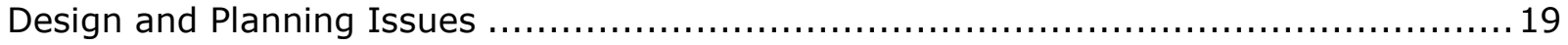

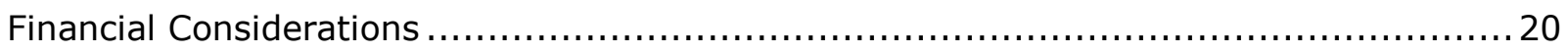

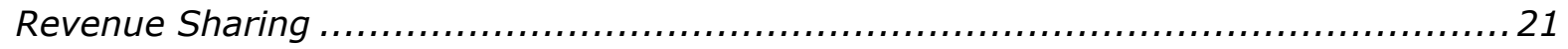

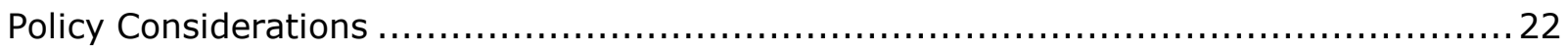

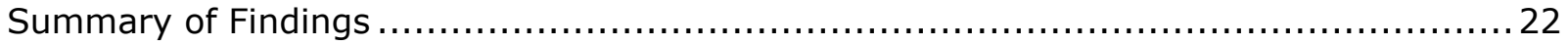

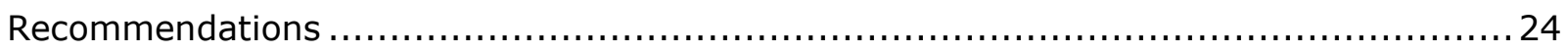

Appendix A Congestion Pricing Projects Open to Traffic in the United States, $2011 \ldots \ldots \ldots . . .26$ Appendix B DOT's Managed Facility Value Pricing Pilot Program Grants, Fiscal Years 2000 -

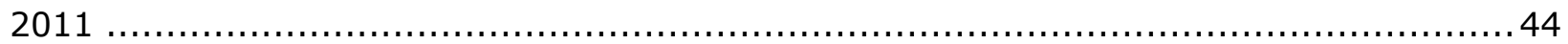
Appendix C DOT's Managed Lane Value Pricing Pilot Program Grants, Fiscal Years 2000 -

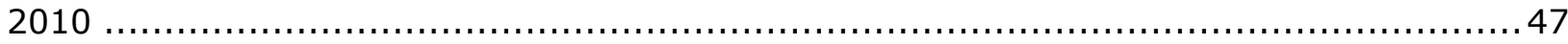




\section{List of Figures}

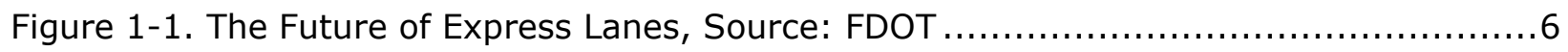

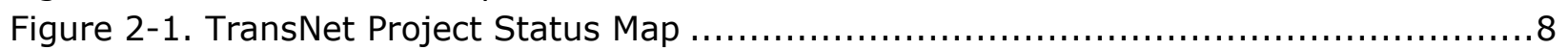

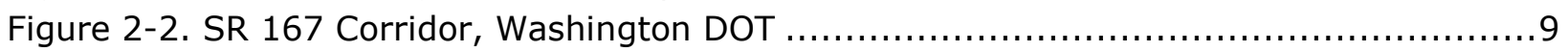

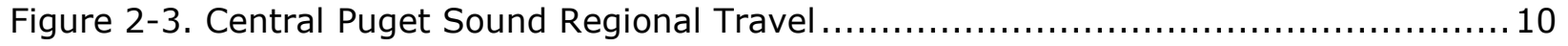

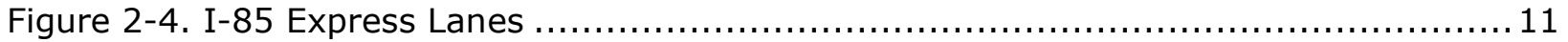

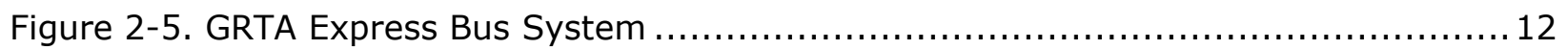

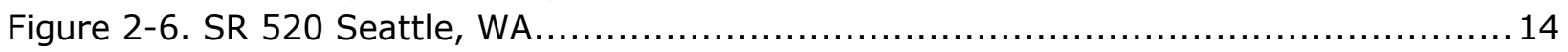

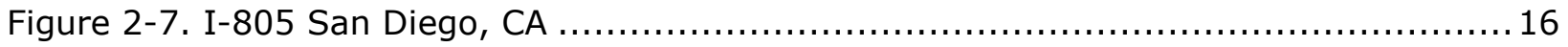

Figure 3-1. Potential Range of Managed Lane Transit Accommodation........................ 19

Figure 3-2. A Decision Framework - Transit and Managed Lanes ........................... 24 


\section{List of Tables}

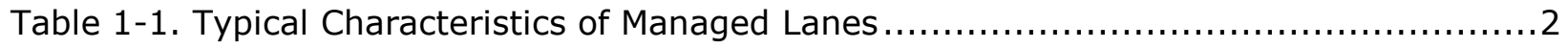

Table 2-1. Selected National Examples - Transit Elements of Managed Lanes.................. 18 


\section{Acronyms}

\begin{tabular}{|c|c|}
\hline AET & All Electronic Tolling \\
\hline AFV & Alternative Fuel Vehicles \\
\hline ARRA & American Recovery and Reinvestment Act of 2009 \\
\hline ATM & Active Traffic Management \\
\hline$B \& T$ & MTA Bridges \& Tunnels \\
\hline BATA & Bay Area Toll Authority \\
\hline BCT & Broward County Transit \\
\hline BRT & Bus Rapid Transit \\
\hline BTL & Bus Toll Lanes \\
\hline CRD & Congestion Reduction Demonstration \\
\hline ELDP & Express Lanes Demonstration Program \\
\hline ETC & Electronic Toll Collection \\
\hline ETL & Express Toll Lane \\
\hline FDOT & Florida Department of Transportation \\
\hline FHWA & Federal Highway Administration \\
\hline FTA & Federal Transit Administration \\
\hline FY & Fiscal Year \\
\hline GDOT & Georgia Department of Transportation \\
\hline GRTA & Georgia Regional Transportation Authority \\
\hline HCTRA & Harris County Toll Road Authority \\
\hline НOT & High-Occupancy Toll \\
\hline HOV & High-Occupancy Vehicle \\
\hline MAP-21 & Moving Ahead for Progress in the 21 st Century Act \\
\hline MDOT & Maryland Department of Transportation \\
\hline MDT & Miami-Dade Transit \\
\hline MdTA & Maryland Transportation Authority \\
\hline METCO & Metropolitan Transit Authority of Harris County \\
\hline MPO & Metropolitan Planning Organization \\
\hline MTA & Metropolitan Transportation Authority \\
\hline NB & Northbound \\
\hline NCTR & National Center for Transit Research \\
\hline NEPA & National Environmental Protection Act \\
\hline NJDOT & New Jersey Department of Transportation \\
\hline NJTA & New Jersey Turnpike Authority \\
\hline NYCDOT & New York City Department of Transportation \\
\hline NYCT & New York City Transit \\
\hline NYSBA & New York State Bridge Authority \\
\hline NYSDOT & New York State Department of Transportation \\
\hline NYSTA & New York State Thruway Authority \\
\hline OCTA & Orange County Transportation Authority \\
\hline PATH & Port Authority Trans-Hudson \\
\hline PDSL & Priced Dynamic Shoulder Lanes \\
\hline PPP & Public-Private Partnership \\
\hline RCTO & Regional Concept of Transportation Operations \\
\hline
\end{tabular}


RITA Research and Innovative Technology Administration

RPC Regional Planning Council

SANDAG San Diego Association of Governments

SB Southbound

SRTA State Road and Tollway Authority

SULEV Super Ultra Low Emission Vehicle

TDM Transportation Demand Management

TIFIA Transportation Infrastructure Finance and Innovation Act

TOT Truck-Only Toll

TRANSCOM Transportation Operations Coordinating Committee

U.S. United States

U.S. DOT United States Department of Transportation

UPA Urban Partnership Agreement

VPP Value Pricing Pilot Program

XBL Exclusive Bus Lane 


\section{Chapter 1 Introduction}

\section{Managed/Priced Lanes Background}

The Florida Department of Transportation (FDOT) has embarked on an extensive program to implement express lanes on congested corridors across the state. In August 2011, the secretary of transportation articulated the governor's transportation vision for the future of Florida's state transportation system. Under the heading of "Creating Choices," development of a system of "managed lanes" was announced. Included in the list of projects that would be a part of the system that would build on the success of the I-95 express lanes in MiamiDade County were I-595 in Broward County, I-75 in Broward County, and Palmetto Expressway in Miami-Dade County.

As traditional transportation funding sources become less sustainable and the demand for mobility increases during the economic recovery, agencies across the United States (U.S.) are looking to the concept of managing highway demand through congestion pricing, and maximizing capacity through the active management of the highway network or employing "managed lanes." A subset of managed lanes is the express lane, discussed below, that involves pricing of lanes parallel to non-tolled lanes to provide an alternative to congested traffic lanes, create transportation choice, and generate toll revenue.

In congested urban areas, the cost of additional capacity can be extremely high and is in some cases prohibitive beyond the next widening of a highway or other major capacity project. Managed lanes can provide long-term congestion insurance through the implementation of dynamic pricing techniques that can guarantee a minimum highway level of service.

Highway lanes that are managed to deal with congestion are by definition located in urbanized areas where the provision of high-quality and reliable transit service can contribute to commuter choice and the reduction of single occupant vehicles (hence congestion) in a corridor. Other facilities that are considered managed lanes can be implemented for other reasons; for example, exclusive commercial use, or simply tolled in order to finance a highway improvement.

\section{Managed Lanes Defined}

According to the Federal Highway Administration's (FHWA) Office of Operations, a managed lane is defined as "highway facilities or a set of lanes where operational strategies are proactively implemented and managed in response to changing conditions." ${ }^{1}$ Operational strategies include pricing, vehicle eligibility, or access control. These strategies can be employed individually on in combinations and permutations.

In its preliminary definitions, FDOT also identifies managed lanes broadly and states that they may include truck lanes, high-occupancy vehicle lanes (HOV), high-occupancy toll

\footnotetext{
${ }^{1}$ U.S. Department of Transportation, Federal Highway Administration, "Managed Lanes Primer," FHWA-HOP-05-031 EDL 14110: August 2008.
} 
lanes (HOT), bus rapid transit lanes (BRT), reversible lanes, and express lanes. While all priced lanes are managed lanes, not all managed lanes use pricing.

Table 1-1 summarizes the operational strategies deployed for various types of managed lanes. The characterizations of the lane types below are general and not absolute, as exceptions can be cited.

Table 1-1. Typical Characteristics of Managed Lanes

\begin{tabular}{lccc}
\hline \multicolumn{1}{c}{ Lane Type } & Pricing & Vehicle Eligibility & Access Control \\
\hline HOV & No & Yes & Situational \\
HOT & Yes & Yes & Situational \\
BRT & No & Yes & Yes \\
\hline Reversible & No & No & Yes \\
\hline Truck Lanes & Situational & Yes & Yes \\
\hline Express Lanes & Yes & Situational & Yes \\
\hline
\end{tabular}

The distinction between express lanes and HOT lanes seems to have become somewhat blurred, and during the conduct of this study, researchers found them often used interchangeably. A HOT lane can be dynamically priced, but offers free passage to vehicles based on occupancy (usually two or more or three or more occupants). In the purist sense of the definition, an express lane is a facility that is priced to provide a less congested alternative with no accommodation for carpools or vanpools. That said, there are examples of express lanes that include high-capacity transit components that allow toll-free passage for transit vehicles.

Many of the funding, operating, and pricing decisions regarding a particular corridor are made based on the strategic objective of the project. This is of significant importance as one considers the role and integration of transit into a managed lane project. Corridors with a strong demonstrated or forecasted public transportation demand will often incorporate design and construction elements that provide superior transit service.

\section{Status of Managed Lanes in Florida}

\section{I-95 Express}

Current FDOT policy has evolved to a point where any new capacity on interstate highways is anticipated to be accomplished through the use of tolls and the deployment of express lanes. FDOT materials reviewed as part of this effort indicate that the terms HOT lanes and express lanes are used interchangeably. These facilities offer an opportunity to provide enhanced transit service in heavily congested urban corridors and, in some cases, without the significant capital investments associated with corridor-wide, high-capacity public transportation systems. 
As a means to assist in the financing of the facilities, statutory changes were made in the 2012 session of the Florida legislature in assist FDOT in implementing a managed lane program. The law allows FDOT to impose tolls on new lanes and on existing bridges in Florida with certain limitations. The language is provided below.

\begin{abstract}
338.151 Authority of the department to establish tolls on the State Highway System.-Notwithstanding s. 338.165(8), the department may establish tolls on new limited access facilities on the State Highway System, lanes added to existing limited access facilities on the State Highway System, new major bridges on the State Highway System over waterways, and replacements for existing major bridges on the State Highway System over waterways to pay, fully or partially, for the cost of such projects. Except for high-occupancy vehicle lanes, express lanes, the turnpike system, and as otherwise authorized by law, the department may not establish tolls on lanes of limited access facilities that exist on July 1, 2012, unless tolls were in effect for the lanes prior to that date. The authority provided in this section is in addition to the authority provided under the Florida Turnpike Enterprise Law and s. 338.166. History.-s. 22, ch. 2012-128; s. 41, ch. 2012-174. (Flsenate.gov Archives, http://www.flsenate.gov/Laws/Statutes/2012/338.151)
\end{abstract}

Policies associated with the integration of public transportation into the planning, design, construction financing, and ongoing operation and maintenance of new managed lanes seem to stem from the motivation of implementing a new or different road pricing strategy. If the principal motivation of an implementing agency is simply to finance the capacity expansion of an otherwise unfunded congested highway through tolling, then the full consideration of integrating transit may not be a priority. If, on the other hand, the implementation of tolls for the first time, or a move to dynamic pricing, is part of a longterm strategy of managing congestion in a corridor, the integration of transit into the project and program is essential and needs to be considered from project concept through the operation of the facility.

To the extent that transit becomes an integral part of a managed lane project that includes tolls and/or pricing, the revised statute provides the opportunity for funding transit operating and capital in a new price-managed facility.

Florida has demonstrated creativity and managed lanes success with the implementation of the first phase of the I-95 Express lanes project in South Florida. FDOT embarked on an ambitious initiative to study, implement, and operate managed lanes as an approach to efficiently and effectively increase mobility. Express lanes have been successfully implemented on I-95 in Miami-Dade County in conjunction with express bus service and are currently being extended into Broward County to connect with a project on I-595, creating the beginnings of a regional network.

The I-95 express lane project is a 21-mile managed lane project, funded through an Urban Partnership Agreement (UPA). The UPA program was established in 2007 by the U.S. Department of Transportation (U.S. DOT) to award discretionary federal grants to cities that demonstrated the most aggressive congestion management projects and techniques. Project proposals for UPA funding were evaluated on deploying strategies labeled the "4Ts": 
Tolling, Transit, Telecommuting (and other demand management strategies), and Technology. The Miami area application was one of five cities selected for funding from the program.

The project included increasing the HOV requirement for toll-free travel in the express lanes from the former 2+ occupants in the HOV to $3+$ for non-tolled travel, and the tolls in the express lanes for non-HOV traffic vary based on the level of congestion on the facility. In addition to the express bus enhancements and park-and-ride elements, ramp metering was also employed. The two express lanes were accomplished through the re-striping of existing pavement and installation of overhead toll gantries and changeable message signs. Surface mounted delineator posts separate the toll lanes from the general traffic lanes. When completed northward into Broward County, this project will serve as the backbone of a regional BRT system for South Florida.

Sixty-foot, hybrid-electric, articulated buses provide express morning service from Aventura Mall, a Park-and-ride lot at NW $183^{\text {rd }}$ Street and NW $73^{\text {rd }}$ Avenue, and the Golden Glades Park-and-ride Lots to Downtown Miami Employment centers and the Earlington Heights MetroRail Station. Rolling stock for the service was procured with funds provided under the UPA for the express lanes implementation. Travel times and average highway speeds have improved on I-95 for the section operating, and the transit service is experiencing positive ridership response.

Acquisition of state-of-the-art buses is a part of the overall funding of the project, as is a multiyear commitment to the operating cost of providing BRT service to the local transit providers, Miami-Dade Transit (MDT), and Broward County Transit (BCT).

FHWA reports the following results for the operating portion of the facility as of 2010: "Transit Improvements - Some additional peak hour transit service added to existing I-95 corridor routes during Phase 1 implementation. Five hundred extra parking spaces added to Golden Glades Interchange in late 2009. Three new transit routes began operating in late January 2010. Twenty-three new articulated buses are being phased in over the next 2 years. Three new transit routes began operating in late January 2010."2

In addition, the annual report states, "Increased 95 Express Bus ridership by an average of 22 percent between the first three months of 2009 and the first three months of 2010, despite a decrease of 12 percent in overall Miami-Dade Transit ridership. Fifty-three percent of new riders on the 95 Express Bus Service said the express lanes influenced their decision to use transit. Thirty-eight percent of new riders said they used to drive. ${ }^{\prime 3}$

More recently, FDOT reports that weekday transit ridership has gone from 1,800 boardings in 2009 to more than 5,000, with dramatic increases in average peak hour speeds for the tolled and non-tolled lanes.

2 U.S. Department of Transportation, Florida Department of Transportation, "UPA/CRD Annual Report, Miami, FL I-95 Express Lanes," FHWA-JPO-11-044, http://www.upa.dot.gov/docs/fhwajpo11044/armiami1.pdf

${ }^{3}$ Ibid. 


\section{I-595 Express Lanes}

This 10.5-mile project is currently under construction and encompasses major improvements to the Interstate from the I-75/Sawgrass Expressway interchange to just west of I-95, and includes significant interchange reconfigurations. The express toll lanes are now being constructed in the median of the facility.

Like the express lanes on I-95, free passage will be available to $3+$ HOVs, and the "595 Express" bus service will provide service to downtown Ft. Lauderdale and the Ft. Lauderdale-Hollywood International Airport. Unlike I-95, the three express lanes will be reversible, carrying suburban commuter traffic eastbound toward downtown in the morning and then westbound in the evening peak hours. The "non-express" portions of the improvement, including widening, auxiliary lanes, and bridge and interchange improvements, are expected to be completed by the end of 2013.

The I-595 project includes significant enhancements to existing express bus service and can be considered BRT; although an exclusive BRT lane is not currently contemplated. The \$1.2 billion I-595 project is expected to be completed in the summer of 2014 and has been financed and constructed through a public-private partnership (PPP) that employed a design-build-finance arrangement.

FDOT views these two initial projects as the beginnings of a larger regional network and is currently engaged in the development of a Regional Concept of Transportation Operations (RCTO) that will define many of the responsibilities, operating parameters, and policies for a regional implementation of express lanes. The initiative includes Metropolitan Planning Organizations (MPO), transit providers, law enforcement, local transportation authorities, the FDOT districts, and the Regional Planning Council (RPC).

The RCTO effort provides the forum to assure that a multimodal strategy is evaluated for the region with the potential that project design elements and operating practices can enhance public transportation across the network. As stated earlier, articulation of the principal policy motivation for the deployment of managed lanes should be the catalyst for arriving at an inclusive concept of operations. While striving for a consistent set of institutional policies for the implementation and operation of a regional network is a laudable goal, there may in fact be unique traffic characteristics and different transit market potential across the 70-plus mile network included in the RCTO. For example, the demand for commuter bus, long-haul premium service is present along I-95 between Miami-Dade and Broward Counties, and the I-95 Express project includes infrastructure and financial support for the BRT service. It may be that other portions of the network lack this demand and, hence, similar transit project components. Conversely, future plans and forecast transit demand could be cause for public transportation enhancements well beyond those included in the I-95 Express lanes.

\section{Other Florida Express Lane Projects}

In addition to the two projects mentioned above, FDOT is actively involved in the preconstruction phases of several other managed lane projects, and Figure 1-1 illustrates the Department's current view of the future of managed lanes. 
A. Northeast Florida Express Lanes - Interstate 295, three segments

- Buckman Bridge to I-95

- SR 9B to J. Turner Butler Boulevard

- Dames Point Bridge to I-95

- Targeted implementation first phase - 2017

B. "Moving-4-Ward" - Interstate 4 from West of Kirkman Road to East of SR 434 Express Lanes

- 21-plus miles

- Approximate cost of $\$ 2$ billion

- In partnership with Florida's Turnpike Enterprise

- Current construction start estimate - Fall/Winter 2014

- Four managed lanes and six general use

C. I-75 PD\&E Study - Miami-Dade and Broward Counties

- From I-595 to SR 826 Palmetto Expressway

- Possible special use lanes

- Transit enhancements

- Phase II may include transit guideway if warrants are met

D. Palmetto Expressway Managed Lanes

- From SR 836/Dolphin Expressway to SR 932/NW 103rd Street

- Approximately six miles

- Considering PPP

- Two managed lanes contemplated

- Estimated cost $\$ 285$ million

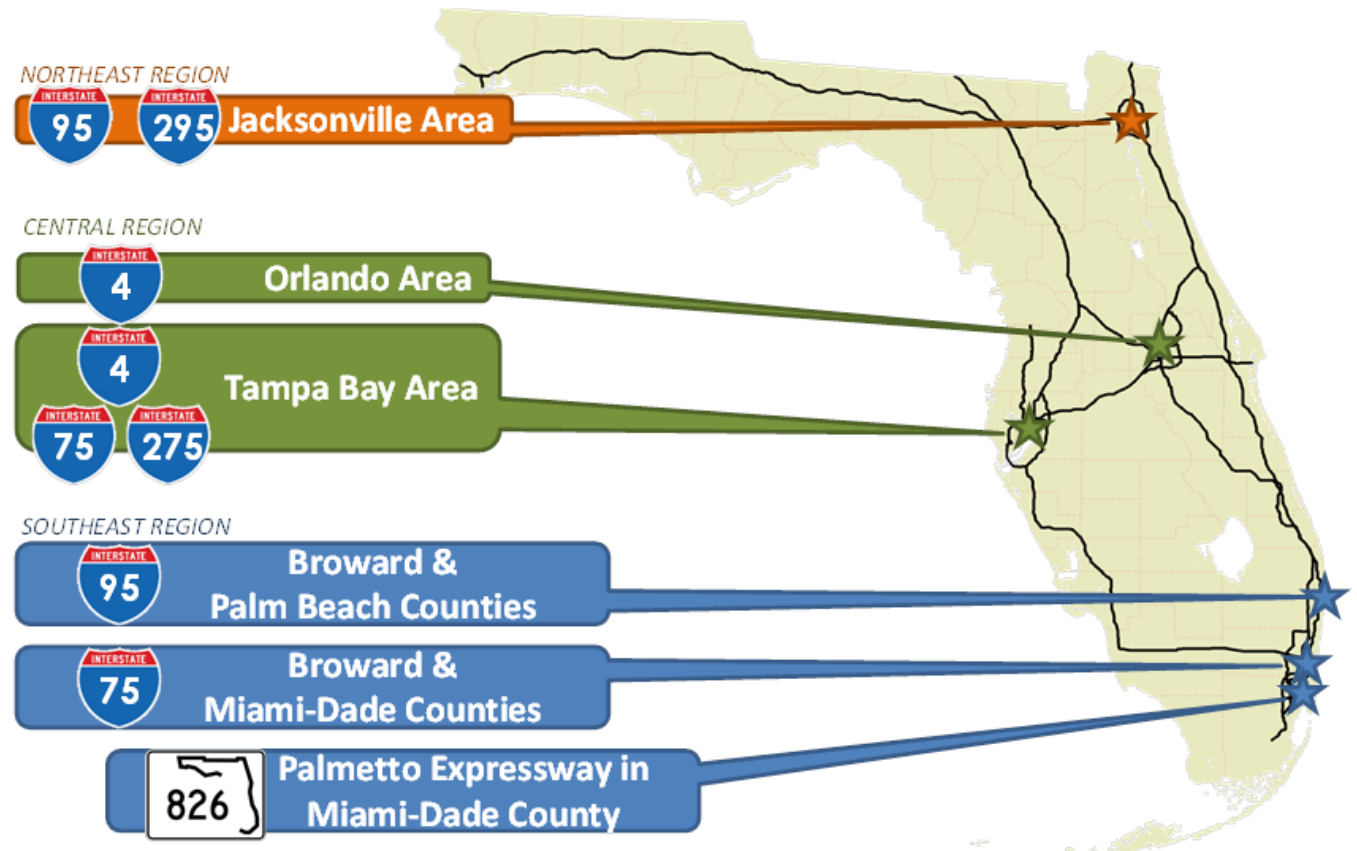

Figure 1-1. The Future of Express Lanes, Source: FDOT 


\section{Chapter 2 \\ National Examples of Transit in Exclusive Lanes}

The literature review for the research project identified at least 15 managed lane projects with what CUTR researchers considered "significant transit" components. A summary of those projects and their features can be found in Appendix B. The 5 projects detailed below represent a subset of the 15 that were determined to have some unique transit features. These projects/facilities were examined more closely to capture the range of public transportation treatments in conjunction with express lane, HOT lane, and new tolling projects.

\section{I-15 San Diego, California}

This 20-mile HOT lane project and facility was the earliest dynamically priced interstate project in the United States, ${ }^{4}$ and is a four-lane variable-priced facility serving customers all day, every day in both directions from the I-15/SR 163 split and Escondido. The project evolved from an early demonstration of price-managed lanes using a decal based entry system in 1996 to an all-electronic HOT "highway within a highway" that has provided over $\$ 7.5$ million in commuter bus subsidy since its inception. ${ }^{5}$ Ultimately, this facility will be a part of a new BRT system that will connect North County communities to regional destinations and other transit modes. Currently, four direct access ramps allow users to enter and exit express lanes from convenient transit stations along I-15. A fifth ramp along with a transit center is expected to be completed in 2014.

An interesting aspect of this project is the publicly accessible TransNet Dashboard, an interactive, online reporting tool that displays how TransNet dollars are being spent. TransNet is the moniker for the program funded by a one-half cent regional sales tax that was extended in $\mathbf{2 0 0 4}$ for $\mathbf{4 0}$ years to fund transportation in the San Diego region. It is administered by the San Diego Association of Governments (SANDAG). Budget and project status are reported through the tool along with a count of completed project phases. Figure 2-1 is taken from the TransNet Dashboard, and Project \#4, denoted in red, illustrates the location of the completed I-15 HOT lane project.

The current tolls for single occupant vehicles range from $\$ 0.50$ to $\$ 8.00$, depending on congestion and distance traveled. Carpools "2-plus" travel with no toll, and direct access ramps are provided for high-frequency BRT service. BRT stations and parking are provided adjacent to the direct access ramps. Ample parking appears to be available for carpoolers, vanpoolers, and transit customers. A major transit center at Mira Mesa is expected to be open next year with direct access to the HOT median facility.

\footnotetext{
${ }^{4}$ Janusz Supernak, "HOT Lanes on Interstate 15 in San Diego: Technology, Impacts and Equity Issues," San Diego State University: 2005.

${ }^{5}$ U.S. Department of Transportation, Federal Highway Administration, "VPP Projects Involving Tolls, Category: Priced Lanes, Sub-Category: High-Occupancy Toll (HOT) Lanes," http://ops.fhwa.dot.gov/tolling pricing/value pricing/projects/involving tolls/priced lanes/hot lanes/ ca hotlanes i15sd.htm
} 


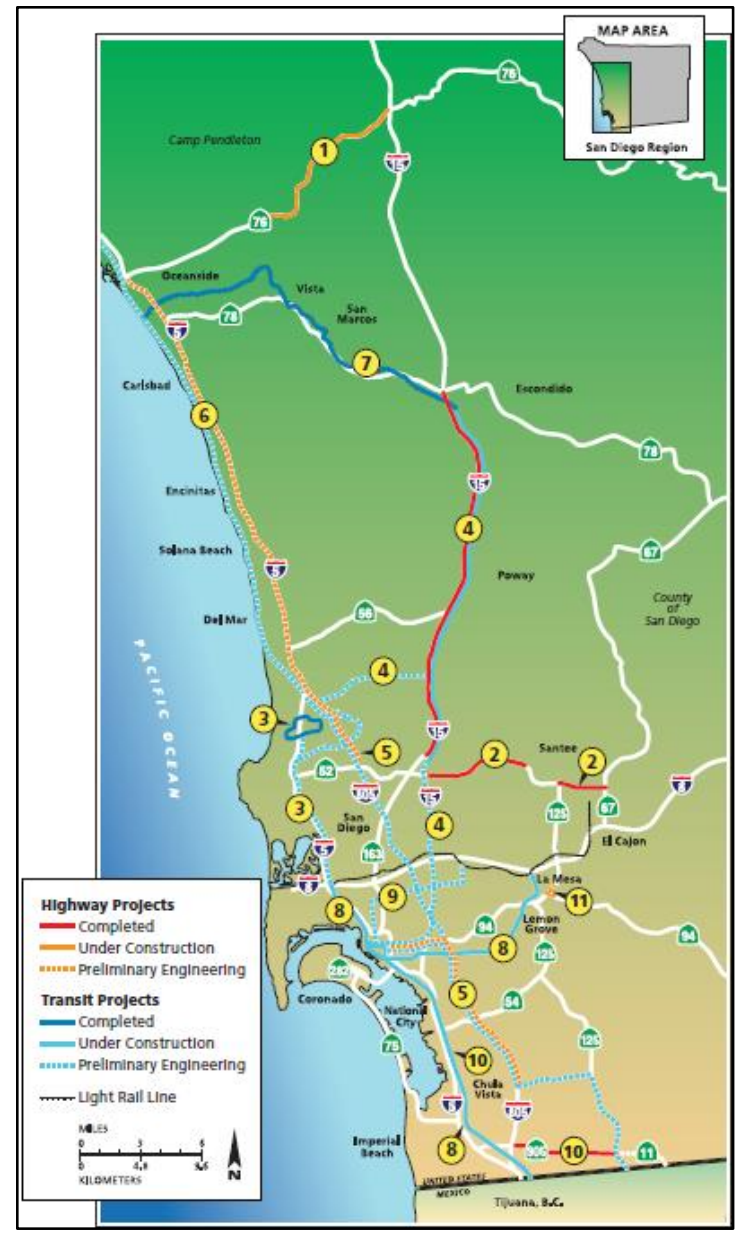

Figure 2-1. TransNet Project Status Map
The ultimate BRT facility will be constructed in three phases with an estimated cost of $\$ 1.3$ billion. Portions of the ultimate design are open to traffic in the form of high-occupancy toll lanes with a moveable center barrier to create a reversible lane. When completed, the project will have five BRT stations with direct access ramps to the new lanes. ${ }^{6}$

Currently, five different express bus routes have been deployed on the facility and a local bus route uses a portion of the HOT lane. Over-theroad coaches were procured as a part of the I-15 project and transit vehicles are not required to pay any tolls, including "deadhead" trips.

The I-15 project includes a number of planning and design elements that should be noted. The first is that the corridor and the transit improvements are part of a much larger BRT plan with implementation occurring in stages. Another interesting aspect is the integration of transit stations and park-and-rides with direct access ramps. Travel times for the transit riders are significantly enhanced by buses not having to travel off the main network to gain access and egress from stations or park-and-ride lots.

Another significant feature of this project is the ongoing public information and awareness efforts by SANDAG. In addition to the dashboard tool mentioned above, there are online newsletters for each project, project-by-project status webpages, and animated videos of projects under development. The entire TransNet program, while managed by the regional planning agency, is a partnership with CalTrans and SANDAG.

\section{SR 167 Seattle, Washington}

This HOT lane facility covers a 10-mile north/south corridor between the cities of Seattle and Tacoma, Washington. For the majority of its length, the highway is four lanes and expands to six lanes near its northern terminus. One HOT lane in each direction employs dynamic pricing and toll rates currently range from $\$ 0.50$ to $\$ 9.00$, depending on trip length and congestion. ${ }^{7}$ The HOT lanes were converted from existing HOV lanes. Extensions to the north and south are being planned with the southern connection to I-5 likely to be funded

\footnotetext{
${ }^{6}$ SANDAG, "I-15 Express Lanes Fact Sheet," San Diego, CA: January 2012, http://www.sandag.org/uploads/publicationid/publicationid 6 1065.pdf

7 Washington State Department of Transportation, "Eight-Month Performance Summary of SR 167 High Occupancy Toll (HOT) Lanes Pilot Project," Seattle, WA: January 2008, http://www.wsdot.wa.gov/NR/rdonlyres/962C3A05-FCF2-483F-884A1569059A0346/0/SR167HOTLns8MnthFinal.pdf
} 
first. An extension to the north involves an extensive and expensive interchange reconfiguration and construction project costing over $\$ 100$ million. Its funding and schedule are uncertain.

The project is one of those funded in part by the FHWA's Value Pricing Program. FHWA reports that revenue continues to exceed forecasts and the average toll currently fluctuates between $\$ 1.00$ and $\$ 1.25$.

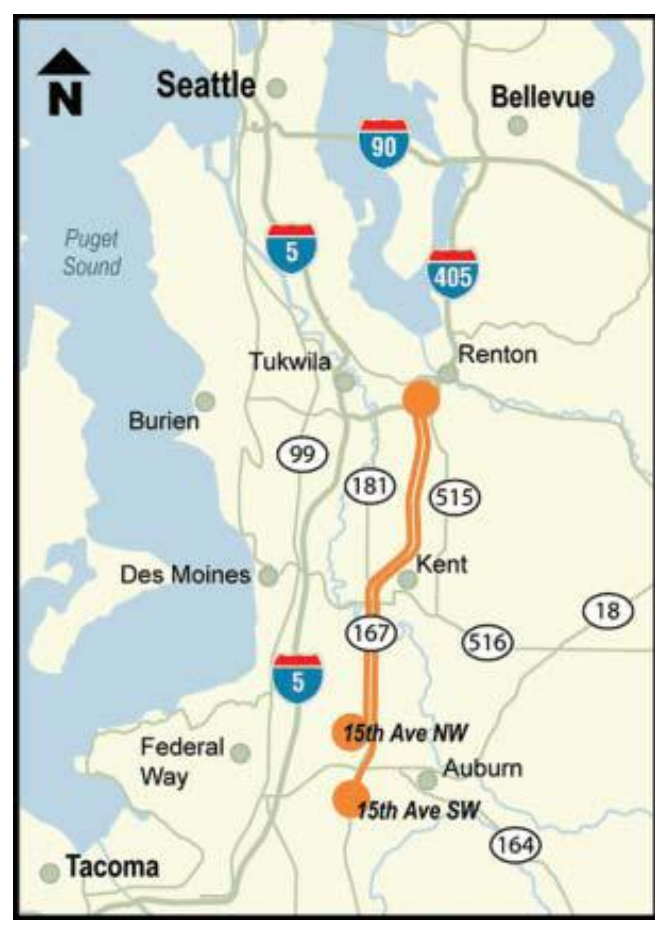

Figure 2-2. SR 167 Corridor, Washington DOT
Currently, 12 separate regional transit express routes operate on SR 167, parallel SR 167, or cross over SR 167 , and 17 local transit routes operate within the corridor and adjacent cities. There are 22 park-andride lots in the SR 167 corridor, and Sounder Commuter Rail operates on tracks that run parallel to SR 167 with five station stops.

The multimodal travel market in this region is very strong. Washington DOT reported to researchers that more than one-half of all trips in the Central Puget Sound region are accomplished through means other than a single-occupant vehicle. Nearly 40 percent of all trips (not exclusively commuter trips) in the region were reported as carpools in a Puget Sound Regional Council survey conducted in 2008 (Figure 2-3).

Washington DOT reported a 25 percent increase in transit ridership over the same period after the HOT lane opening, even though travel times for transit riders have not significantly decreased. Two express bus route alignments were slightly "tweaked" in order to optimize bus access to and from the lanes.

Single-occupant users of the facility must have a toll transponder (Good to Go!), while carpools, vanpools, and transit vehicles travel with no toll and do not require transponders. The transponders are switchable to allow account holders to carpool without charge. The HOT lanes are not barrier-separated and employ pavement markings to designate lanes and exit and entry points.

The project opened in 2008 at a capital cost of $\$ 18$ million and operates from 5:00 a.m. to 7:00 p.m. every day, with trucks over 10,000 pounds Gross Vehicle Weight prohibited from 
use. $^{8}$ For fiscal year (FY) 2012, revenues were reported at $\$ 1,128,915$ and expenses at $\$ 787,745 .^{9}$

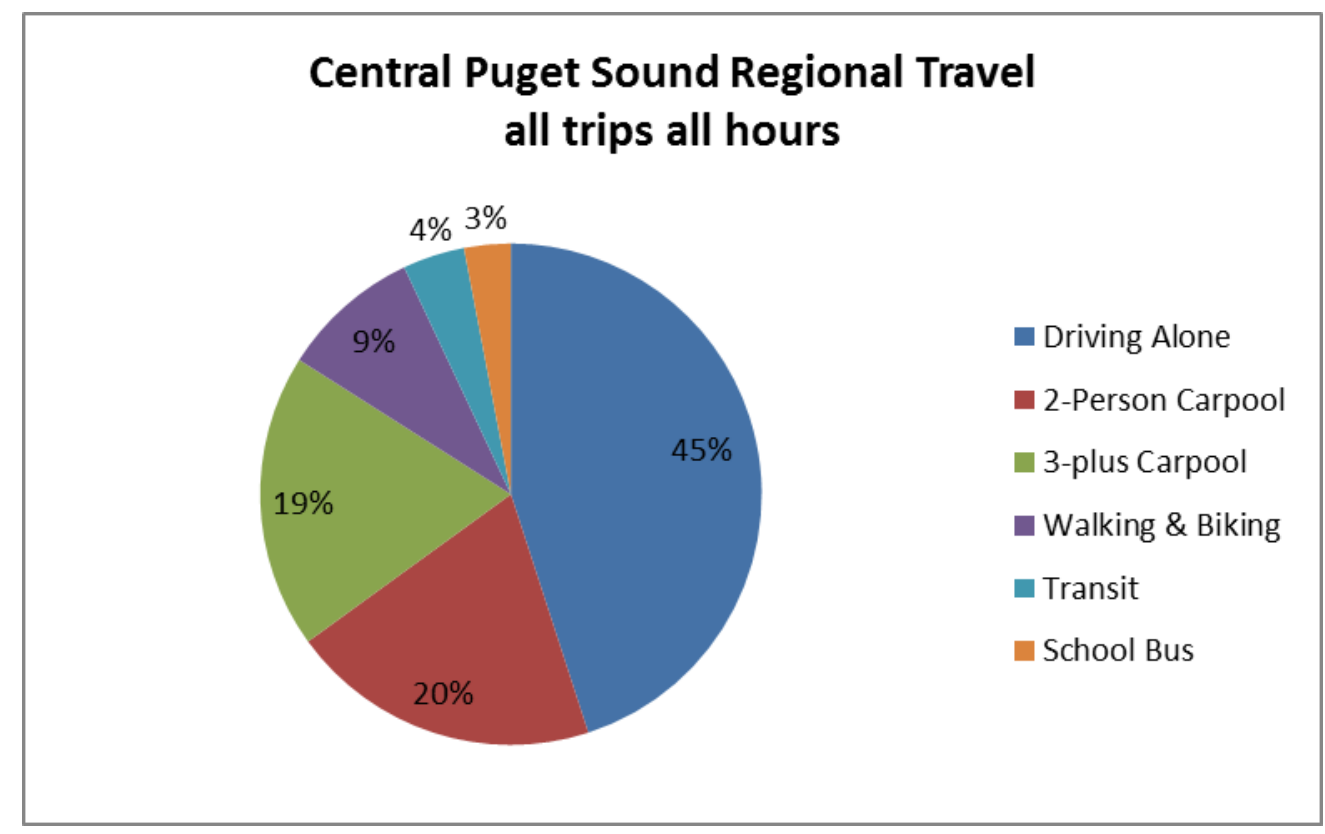

Figure 2-3. Central Puget Sound Regional Travel ${ }^{10}$

While the transit component of this managed lane project is strong, funds for public transportation vehicles, transit operating, and maintenance were not part of the financing. Transit vehicles using the facility are not charged a toll. A financing policy issue was identified in the investigation of this project. The state constitution prohibits the use of gasoline tax revenue on any projects other than highway improvements. Toll revenues from the SR 167 project are, theoretically, available to increase transit, vanpool, carpool, and other services in the project corridor. However, these provisions are apparently under discussion and debate.

\section{I-85 Atlanta, Georgia}

This project in the Atlanta region is a 15.5-mile HOT lane facility that employs dynamic pricing. The first phase of the project involved a combination of state and federal and highway and transit funding. The project is part of an approximate $\$ 182$ million in targeted investments to reduce congestion in the region. The project has been made possible through a Congestion Reduction Demonstration (CRD) grant of $\$ 110$ million that was awarded by FHWA in 2008. The CRD program is a follow-on to the Urban Partnership program.

\footnotetext{
${ }^{8}$ U.S. Department of Transportation, Federal Highway Administration, "SR 167 HOT Lanes Pilot Project," Version 1, 8/23/10, http://ops.fhwa.dot.gov/freewaymgmt/publications/documents/ nrpc0610/workshop_materials/case_studies/seattle.pdf

9 Washington State Department of Transportation, "High Occupancy Toll Lanes Operations Account," September 2012, http://www.wsdot.wa.gov/NR/rdonlyres/76BE5D22-289A-46B3-891267CBC1ECF787/0/SR167HOTLanesFSFY12Q4Final.pdf

${ }^{10}$ Puget Sound Regional Council, "Household Travel Survey, 2006," http://www.psrc.org/data/surveys/2006-household/
} 
Of the $\$ 182$ million, 67 percent will be targeted at transit investments including new and expanded park-and-rides and new over-the-road passenger coaches. These investments are being made through a partnership of the State Road and Tollway Authority (SRTA), the Georgia Regional Transportation Authority (GRTA), the Georgia Department of Transportation (GDOT), and other federal and local agencies.

The facility currently extends from Old Peachtree Road northeast of Atlanta to Chamblee Tucker Road, just south of I-285, the circumferential interstate around Atlanta, on the eastern section (Phase I). This project is part of a regional network of managed lanes being planned and implemented. There is a 10 -mile extension to this facility currently under development that will widen and add HOT lanes on I-85 north of the existing terminus of the express lanes to the area on Figure 2-4 labeled with the Hamilton Mall park-and-ride.

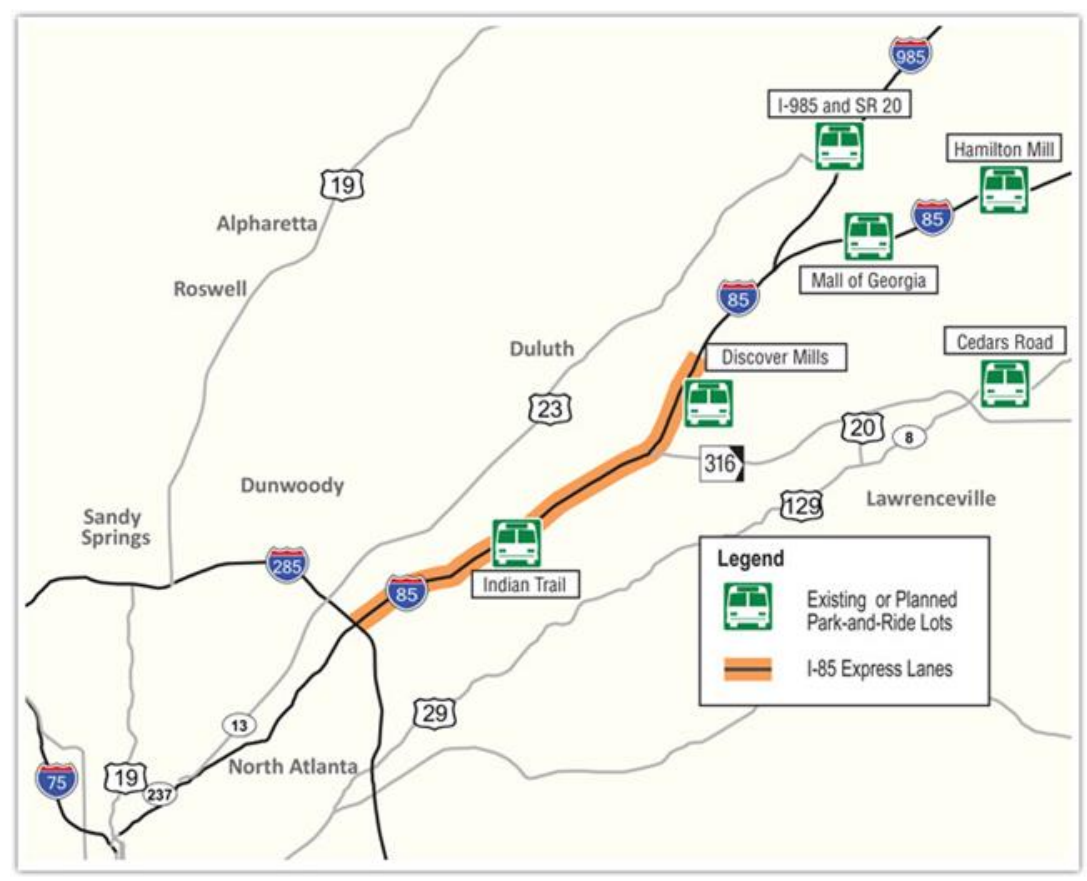

Figure 2-4. I-85 Express Lanes ${ }^{11}$

The operating segment was a conversion of existing HOV lanes to HOT lanes. Registration is required for toll-exempt vehicles, which include carpools with three or more occupants, motorcycles, transit and emergency vehicles, and alternative fuel vehicles (AFV) with the proper AFV license plate. Currently approximately 25 percent of customers use the HOT lane for free (transit included). A portion of Phase I funds was used to build two new park-andride facilities (creating 1,900 additional parking spaces for transit users) and the purchase of 36 new commuter coach buses that support seven routes serving the project corridor. Figure 2-5 illustrates the express bus system currently operating in the region, including the routes on the I-85 planned and existing HOT lanes.

${ }^{11}$ http://www.peachpass.com/peach-pass-toll-facilities/about-i-85-express-lanes 


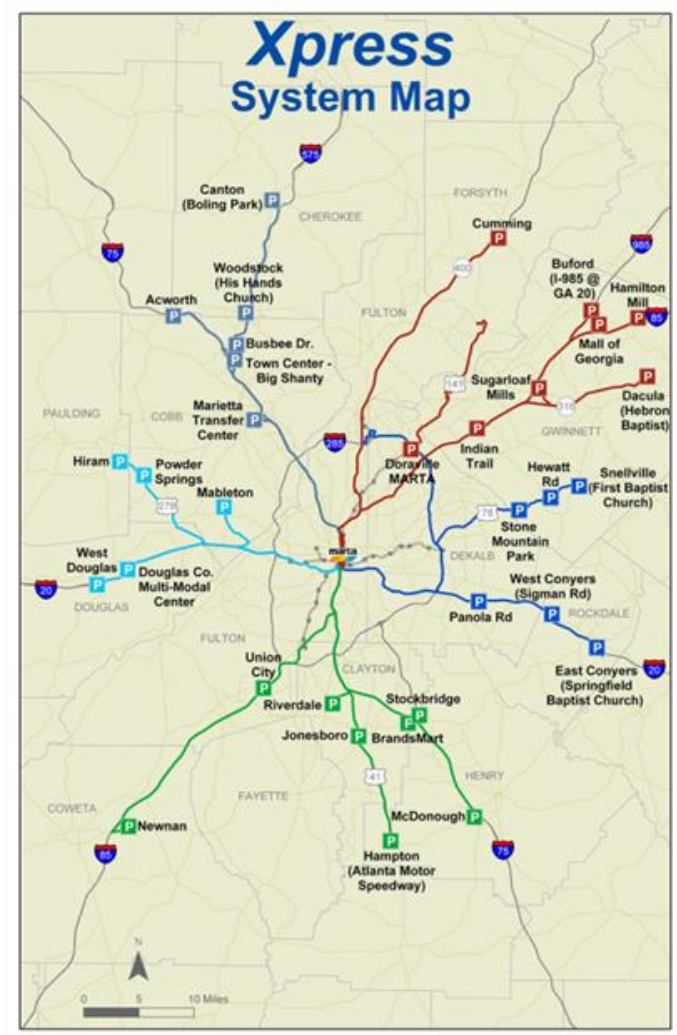

Figure 2-5. GRTA Express Bus System ${ }^{12}$

A robust public outreach and education program was undertaken and continues as support for the regional express lane plan. As part of the National Environmental Protection Act (NEPA) process, about 600 people attended and had the opportunity to provide feedback at eight public information open houses and a public hearing open house in 2009. Participant feedback included concerns about equity and enforcement, the effects of revised occupancy requirements on two-person carpoolers, and an interest in the technology the project will bring to the region.

In addition, six focus groups were conducted with single-occupant drivers and carpoolers as well as a survey of more than 700 carpoolers in the I-85 region. One-on-one briefings with stakeholders, legislators, and the media took place and a project website for the public was established. The expansion of transit in the I-85 corridor is a major component of this project, and the metro Atlanta Region's Concept 3 Transit Vision includes expanded rail and BRT in the corridor that could potentially be incorporated into a future expanded HOT network.

Funds generated from the HOT lanes will be used to defray the costs of construction, operation, and maintenance of the lanes, and the future allocation of excess revenues is currently being studied. The facility's dynamic pricing results in a toll costing between $\$ 1.55$

12 "Xpress commuting made easy!" Atlanta, GA: 2004-2013, http://www.xpressga.com/index.php?option=com content\&task=view\&id=38\&Itemid=75\# 
and $\$ 13.95$, and while toll paying was slow to start, traffic has risen since the opening. It is estimated that more than 90 percent of customers will play less than $\$ 5.00$ for their HOT lane trip.

State transportation issues in Georgia are overseen by the State Transportation Board, a 14-member body elected by a majority of the state assembly's caucus from each of the state's congressional districts. Along with other important duties, the Board approves longrange transportation plans and oversees the DOT. In 2007 it passed a resolution relating to managed lanes in the Atlanta region. Major policy points included the following:

- All new capacity lanes within limited access corridor in Metro-Atlanta shall be managed.

- Mobility shall be guaranteed in managed lanes.

- Lane management relies on eligibility, congestion pricing, and/or accessibility.

- Each solution will be tailored to individual corridor needs. ${ }^{13}$

Further, in 2009 the State Transportation Board passed another resolution that adopted the managed lane system plan as a guide to use in developing individual managed lane projects within Metro-Atlanta. Most recently, in May 2012 the Board resolved to direct the GDOT staff to actively "collaborate with transit and multi-use trails initiatives within individual Managed Lane project corridors so as to foster thoughtful utilization of the existing asset on each corridor for both highway and transit modes." ${ }^{14}$

Not only does the Greater Atlanta region have a well-defined plan for express lanes and integration of express bus and support facilities, but it also has a well-defined set of policies for their implementation.

\section{SR 520 Seattle, Washington}

The State Route 520 project in Seattle, Washington, was one of the more unique projects reviewed. The project manager for this study and researchers agreed that this project could have particular relevance to Florida. The project is being partially funded under a UPA and includes the replacement of a "floating bridge" and the addition of a one HOV lane in each direction for a total of 13 miles. Eventually, the project will extend from the eastern shore of Lake Washington, across the bridge, and connect with Interstate 5 to the west. In 2009 the project cost was estimated at $\$ 4.65$ billion, but has been recently revised downward by $\$ 522$ million based on selection of preferred alternatives and more refined plans. ${ }^{15}$ Most notably, the western approach has been significantly redesigned eliminating an extensive multi-structure interchange with the "floating bridge."

\footnotetext{
${ }^{13}$ State of Georgia, County of Fulton, "A Resolution by the State Transportation Board," 2009, http://www.dot.ga.gov/informationcenter/programs/studies/managedlanes/Documents/Signed\%20GD OT\%20Board\%20Resolution\%20_12_23_09.pdf

${ }^{14}$ Georgia Department of Transportation, "Resolution of the State Transportation Board," 2012, http://www.dot.ga.gov/aboutGeorgiadot/Board/Documents/Resolutions/2012/May/ManagedLanesReso lution.pdf

${ }^{15}$ Washington State Department of Transportation, "SR 520 Program - Costs, Funding and Tolling," 2013, http://www.wsdot.wa.gov/Projects/SR520Bridge/financing.htm
} 
The bridge project is all electronically tolled and variably priced from 5:00 a.m. to 11:00 p.m., seven days per week. Peak hour travel times are reported to have improved by 12 to 15 minutes and tolls are collected either via the "Good to Go" 6C sticker tag transponder or through a pay by plate type of mail system. The existing bridge has been re-tolled and the replacement bridge is under construction.

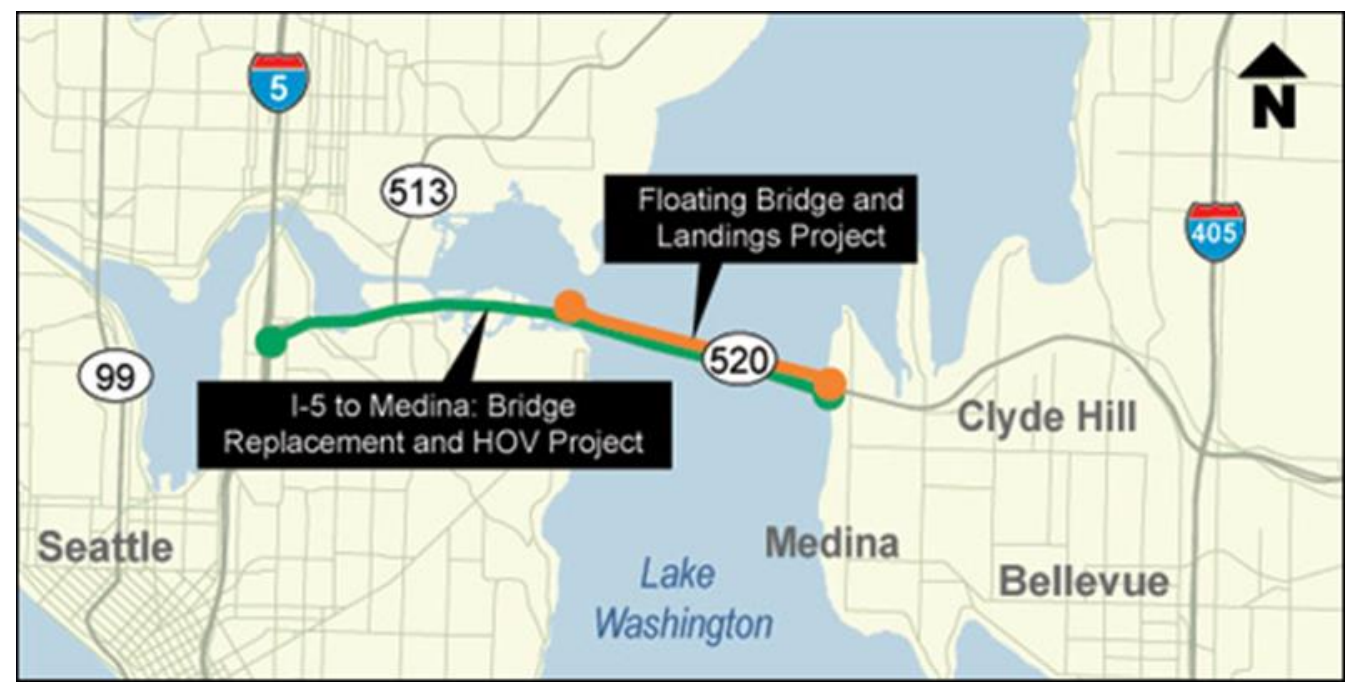

Figure 2-6. SR 520 Seattle, WA ${ }^{16}$

The bridge had originally been tolled when it opened in 1963, and the tolls were lifted in 1979 when the original bonds were retired. There is no high-occupancy vehicle exemption from the toll, but registered vanpools and transit vehicles travel toll-free.

Public transportation enhancements are significant elements of this project, and both Sound Transit and King County Metro provide service in the corridor. One hundred thirty bus trips have been added to routes on SR 520 for a total of 700 trips every weekday. One new route has been added to the corridor, and improvements to bus stops and park-and-rides are completed and underway.

The new SR 520 Bridge is scheduled to open in 2014 with two general-use lanes and one HOV lane in each direction, for a total of six lanes. The bridge spans Lake Washington and links two interstate highways in metropolitan Seattle. Current (FY 2012) Average Weekday Traffic is over 63,000, which is 12 percent above forecasts, and Average Weekend Traffic is running 36 percent ahead of forecasts, at over 38,000. Adjusted gross revenue for FY 2012 is nearly $\$ 26$ million, representing 8 percent over forecast revenue.

Other transit considerations for the toll bridge/HOV corridor include integration of potential future light rail and the construction of a regional bicycle and pedestrian path, direct access ramps to the HOV lanes, and median transit stops along the facility. "Twenty 60 -foot and twenty-five 40-foot hybrid motor coaches are being purchased, and bus stops will be improved through real-time information signs about bus arrivals (at seven stops) and improved passenger shelters and lighting (at two stops). Park-and-ride facilities are being

${ }^{16}$ http://www.wsdot.wa.gov/Projects/SR520Bridge/BridgeAndLandings/Maps.htm 
expanded by replacing a 613-space surface parking lot with an 853-space parking garage and also by building a new 386-space parking garage." 17

An active traffic management system (ATM) was employed in the corridor. The system includes the SR 520 route as well as the parallel I-90 corridor to the south. Transportation Demand Management (TDM) strategies are also being incorporated as a part of the UPA, including continuation of employer-based and community-based trip reduction programs, a robust vanpool program, outreach efforts to more fully implement new telework programs and an aggressive rider sharing network.

The objective of the reintroduction of tolling on the SR 520 bridge was to finance the construction of a new bridge, fund a new HOV program, and alleviate congestion. Federal funds have been used for rolling stock procurement and equipment, and transit ridership began to increase even before bridge tolls were initiated. The transit market is strong in the highly urban and heavily traveled area that serves high-tech employees and employers. Washington DOT reported that transit serves about 20 percent of all trips in the corridor and that ridership experienced a 25 percent increase since the project's implementation. It was also reported that the reliability for transit travel time has increased dramatically.

As was stated in the SR 167 project profile, the Washington State Constitution restricts the use of motor fuel taxes collected by the state to "highway purposes" and, thus, places some limitations on the funding of transit components in a congestion reduction program. It should be noted that when the state legislature passed the bills needed in order to implement tolls on the bridge and enforce toll violators, it also passed a measure to increase funding for transit in 2008.

The issuance of toll revenue bonds with the provisions that toll revenues must be used as authorized by the legislature for bond payments, operations, and maintenance within the SR 520 corridor seems to present an opportunity for future transit maintenance and operations funding.

\section{I-805 San Diego, California}

This multi-phase project covers approximately 27 miles from well north of the City of San Diego to south of the city near Chula Vista along the I-805 corridor. I-805 is a major north/south interstate that parallels I-5 to the east with average daily traffic over 260,000 on the heaviest traveled sections. The corridor has been divided into three sections for project development and construction. Portions of the I-805 "North" and "South" projects have funding programmed, while no funds for the I-805 "Middle" project have been identified (Figure $2-7$ ). ${ }^{18}$

17 U.S. Department of Transportation, Federal Highway Administration, "Seattle (Lake Washington) Urban Partnership Agreement," http://www.upa.dot.gov/agreements/seattle.htm

18 SANDAG, "Interstate 805 Corridor," 2012, http://www.keepsandiegomoving.com/I-805-Corridor/I805-intro.aspx 


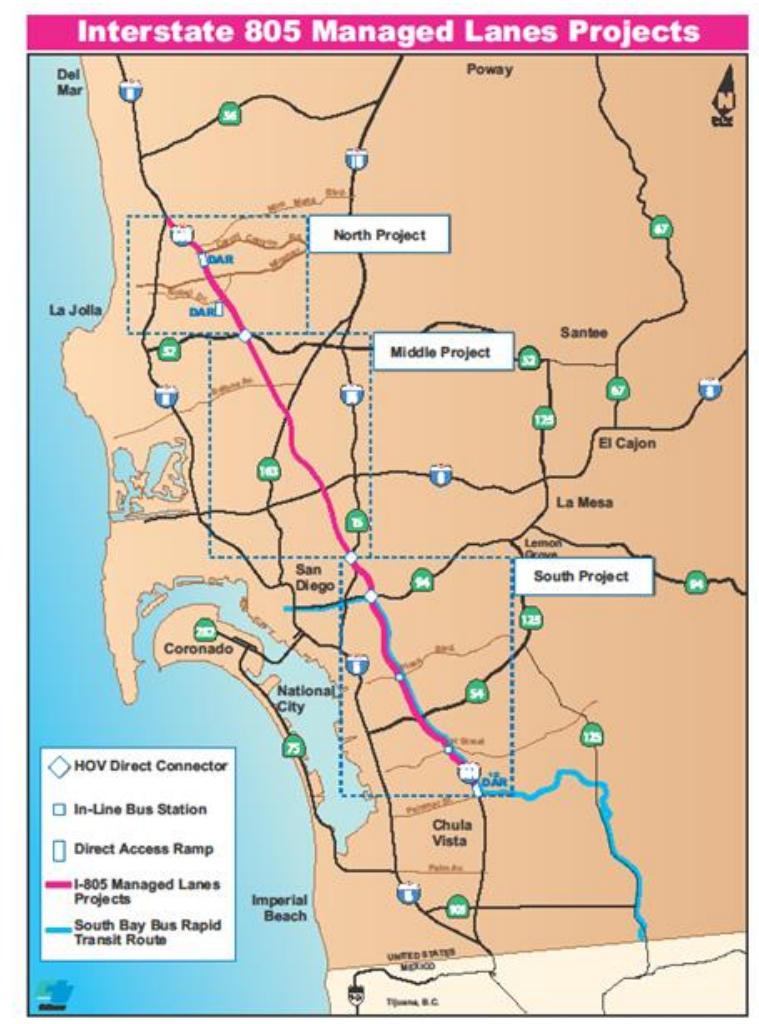

Figure 2-7. I-805 San Diego, CA

SANDAG was awarded $\$ 100$ million by the California Transportation Commission to build two HOV lanes on I-805 for access by carpoolers and transit riders along portions of the corridor. The ultimate design will accommodate the South Bay BRT project, a 21-mile rapid, high-frequency transit facility providing service between the Otay and Mesa border crossing and downtown San Diego. The Draft Environmental Impact Report has been completed for the South Bay project and will become an integral part of the managed lane operation on the I-805 South segment. The BRT project is expected to be in service in 2014 and in the long term will operate on HOV lanes on SR 94 and along the I-805 managed lanes with direct access ramps connecting freeway stations/park-and-ride lots. The South Bay BRT is consistent with the regional plan to create an HOV/managed lane network in the region of more than 200 miles along I-5, I-15, and State Routes 52, 78, 94, and 125.

Each of the funded managed lane projects, I-805 South and I-805 North, involves several phases. Phase I of the South portion is under construction and includes adding HOV lanes, one lane in each direction, of the ultimate two in each direction that will include express or HOT lanes. The construction includes elements to facilitate the ultimate BRT system, including direct access ramps, transit station, and sound barriers. Phase II, planned to take place from 2015 to 2020, will complete the widening, add in-line BRT stations, and provide direct connections to other managed lanes in the network. The total I-805 South project cost is currently estimated at $\$ 1.4$ billion.

The I-805 North project represents a four-mile portion of the entire project with the first of five phases underway. Total project cost is estimated at $\$ 587$ million and will be constructed 
over several decades. Phase I, with an estimated cost of $\$ 87$ million, includes the first lane of the widening, direct access ramps, a park-and-ride and transit station, and noise barrier improvements. Phase I is scheduled for completion in 2015.

The portion of the I-805 corridor of particular interest is the "South" project. The improvements are beginning with the addition of an HOV lane in each direction and basic amenities to accommodate the South Bay BRT line. As funding becomes available and congestion warrants, the next lane in each direction will be added and then dynamically priced. When fully operational, the new HOT lanes will allow toll free passage for two-plus carpools, transit vehicles, and permitted alternatively fueled vehicles. As no revenue will be collected until Phase II, decisions on funding transit have not been made.

Phase I of the I-805 project is expected to be completed in 2014. Phase II of the project that will include the full express lane facility is tentatively scheduled to begin in 2015 and includes in-line transit stations in Chula Vista and National City. This phase also includes direct connections to other managed lane facilities on the network.

This project appears to be an example of total integration of transit into a managed lane project along with a demonstrated vision of a long-range plan for congestion management. The phasing from HOV to HOT to BRT and connection to a regional system of managed lanes is unique among the projects examined in this study.

\section{Project Review Summary}

For the five projects reviewed in this section, no tolls were charged for transit vehicles even in the case of the SR 520 Bridge/HOV project where no high-occupancy toll discount is provided (pure express facility). For the express lane project along I-85 in Atlanta, a carpool of three or more will be required in order to travel the lane toll-free along with other exempt vehicles (transit and vanpools). 
Table 2-1. Selected National Examples - Transit Elements of Managed Lanes

\begin{tabular}{|c|c|c|c|c|c|}
\hline & $\begin{array}{c}\text { I-15 } \\
\text { San Diego } \\
\text { CA }\end{array}$ & $\begin{array}{l}\text { I-85 } \\
\text { Atlanta } \\
\text { GA }\end{array}$ & $\begin{array}{l}\text { SR } 167 \\
\text { Seattle } \\
\text { WA }\end{array}$ & $\begin{array}{l}\text { SR } 520 \\
\text { Seattle } \\
\text { WA }\end{array}$ & $\begin{array}{c}\text { I-805 } \\
\text { San Diego } \\
\text { CA }\end{array}$ \\
\hline $\begin{array}{l}\text { Toll Charge for } \\
\text { Transit }\end{array}$ & no & no ${ }^{1}$ & no & no & no \\
\hline HOT & $2+$ & $3+$ & $2+$ & no & $\begin{array}{c}2+ \\
\text { (ultimate) }\end{array}$ \\
\hline Transit Capital & yes & yes & no & yes & yes \\
\hline Transit Operating & possible & possible & no & possible & possible \\
\hline Reversible & yes & no & no & no & no \\
\hline $\begin{array}{l}\text { Direct Access } \\
\text { Ramps }\end{array}$ & yes & & no & yes & ultimate \\
\hline $\begin{array}{l}\text { Park-and-Rides } \\
\text { Funding }\end{array}$ & yes & yes & no & yes & yes \\
\hline $\begin{array}{l}\text { Transit Station } \\
\text { Funding }\end{array}$ & yes & yes & no & yes & ultimate \\
\hline Federal Program & $\begin{array}{l}\text { Value } \\
\text { Pricing }\end{array}$ & CRD & $\begin{array}{l}\text { Value } \\
\text { Pricing }\end{array}$ & UPA/RITA ${ }^{2} / \mathrm{FTA}^{3}$ & $\mathrm{AARA}^{4} / \mathrm{FTA}$ \\
\hline $\begin{array}{l}\text { Implementing } \\
\text { Entity }\end{array}$ & MPO/DOT & State DOT & State DOT & State DOT & MPO/DOT \\
\hline $\begin{array}{l}{ }^{1} \text { Transit vehicles requ } \\
{ }^{2} \text { Research and Innov } \\
{ }^{3} \text { Federal Transit Adm } \\
{ }^{4} \text { American Recovery }\end{array}$ & $\begin{array}{l}\text { to register } \\
\text { Technolog } \\
\text { Reinion. } \\
\text { Reinvestme }\end{array}$ & Act of ? & & & \\
\hline
\end{tabular}

It seems fairly common for park-and-ride lot construction and expansion to be included in the construction cost of a managed lane capital project, and in corridors with high transit demand, station funding along with direct access ramps to and from the stations to the managed lanes are included in the project. While the purchase of new and/or additional rolling stock was a capital cost included in four of the five projects, transit operating subsidies were not being provided in any of the cases.

It appears that for at least this project set, the level of transit integration into the managed lane project is related to the federal program used to fund a portion of the project. This may be due to the nature of the federal eligibility requirements for programs like the Urban Partnership Program and the Congestion Relief Demonstration Program. By definition, these programs are targeted at corridors that are in markets with a high transit demand. In addition, where projects are being developed in conjunction with local governments (which are also typically responsible for providing and funding public transportation services) there may be an added motivation to include more aggressive transit treatments in a managed lane project.

The policy motivation for the employment of managed lanes along with the market potential for public transportation are certainly relevant factors in the funding agency's treatment of transit in managed lanes. This will be explored more in the final section of this report, Findings and Recommendations. 


\section{Chapter 3 \\ Findings and Recommendations}

\section{Design and Planning Issues}

Several issues have emerged as agencies contemplate transit and managed lane projects. Involvement of transit agencies in the development of a project as early as possible in the concept development is vital to having public transportation elements considered as a managed lane project or system evolves toward design and implementation. Existing and future transit demands should be assessed and matched with the appropriate level of service and infrastructure investment before decisions on these issues are finalized. Planning for some of the corridors examined in this report has resulted in right-of-way reservation for future fixed guideway investment.

Transit treatments for the projects reviewed in this study ranged from exclusive transit access ramps and park-and-ride or BRT stations to express buses using the high-occupancy vehicle lane or high-occupancy toll lanes. Several managed lane projects included facility design provisions for future rail construction in the corridor. Aggressive public outreach, partnership building, and marketing have been stressed in the success of several of the projects that incorporated transit treatments into a managed lane project. In addition, "offcorridor" design elements have also been implemented as transit components of managed lane projects, including signal prioritization and surface road improvements for easier access to transit stations.

Figure 3-1 illustrates a range of the intensity of potential transit treatment that can or has been considered for integration into managed priced lane projects. Dedicating an exclusive BRT running way was not found in the research for this project, but incorporation of a BRT line that uses a piece of a managed lane facility is occurring in the I-805 South project and reservation of a light rail right-of-way is a part of the SR 520 improvement in Seattle.

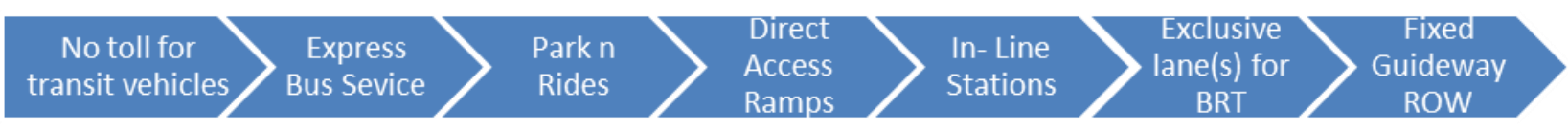

Figure 3-1. Potential Range of Managed Lane Transit Accommodation

Some preliminary transit design would be highly desirable in the engineering of an express lanes project. One lesson learned identified in this study is that an envelope that was reserved for light rail ultimately proved to be too narrow for the efficient design of a BRT facility. As an example, the cross-section was not able to ideally accommodate multipurpose buses with right-side loading only. Some preliminary engineering to understand more fully the requirements of several transit modes seems prudent in corridors with a potential or existing transit market that warrants this level of transit accommodation.

Similarly, without some preliminary engineering effort, median stations with direct access to "inside" express lanes have been precluded because of insufficient median width even 
though there was an intention to do so. The travel time to and from a transit stop that is off the facility results in longer and less predictable transit trip times. The feeder system of local roads and streets should also be examined if high-capacity transit service will be provided along a managed lane corridor. Traffic engineering treatments such as exclusive turn lanes, signal prioritization, and adequate turning radii for larger transit vehicles will assist in improving the off system access to a park-and-ride or transit station.

As the State of Florida moves toward developing policies and procedures for implementing managed lanes statewide, the need for a sketch level planning transit market analysis may be worth considering as a prerequisite to serious discussions on planning, designing, and operating the proposed facility. Appropriate passenger demand including passenger volumes and trip lengths associated with successful commuter bus or express service can then be better matched with managed lane planning and operational decisions. This is particularly important in corridors without existing commuter bus service and where there is no known, established market.

\section{Financial Considerations}

For the projects studied, there is a variety of financial arrangements to pay for transit in express or priced lanes. The most common seemed to be the inclusion of capital construction elements of projects to enhance public transportation service or amenities. As mentioned above, park-and-ride lots (new or expanded) are common, as is the purchase of new transit rolling stock to serve the facilities. While transit taxes are used to fund some projects, the sharing of toll revenues does not seem to be widespread.

The changes in Florida statute mentioned in the introduction to this report seem permissive enough to allow the use of tolls from new express lanes to cover transit operating and capital costs. If, for example, BRT was included in a new express lanes project, the civil construction work, vehicle acquisition, and operating costs could be covered, or at least shared, using toll revenue.

The most generous transit financing arrangements that were reviewed are associated with projects implemented under the UPA and the CRD programs sponsored by the Federal Highway Administration. In some states, these projects were managed lane initiatives and have set expectations that all managed lane projects will include use of toll revenue for transit operating and maintenance subsidies, vehicle acquisition, and other public transportation enhancements.

A misconception exists for some that when tolling is implemented, the HOT or express lanes will generate an extraordinary amount of revenue. Depending on the cost of the project and the plan of finance, it is unlikely that the tolls will cover the capital and operating costs of the physical roadway elements. The use of toll revenue bonds by different entities with different pledges to bondholders can limit the use of funds generated on the facility. While most toll bond trust agreements have strict provisions relating to the toll-free use of facilities, there are typically clauses giving latitude to the rate-maker for exceptions. While this may address the ability to allow transit vehicles, vanpools, and other high-occupancy vehicles to use the highway toll-free, the priority for the use of toll revenue is strictly defined and will vary. This may place restrictions on the use of revenue bond proceeds for 
the capital and ongoing operating costs of the public transportation components of an integrated managed lane project that is toll-financed.

As in other high-capacity transit facilities, there is potential for revenue generation from non-fare sources such as joint development at stations, naming rights, and advertising. While not unique to transit facilities integrated with a managed lane project, these financing mechanisms should not be overlooked in the project development and financial planning processes.

Given that there are many potential funding and operating partners in Florida (FDOT, Florida's Turnpike Enterprise, local and regional expressway or transportation authorities), hard and fast rules for what will or will not be a part of a project sponsor's cost may not be the best approach.

\section{Revenue Sharing}

The concept of Bus Toll Lanes (BTL) is being explored and could be evaluated as a part of future priced lane projects. In a white paper prepared by the National Center for Transit Research (NCTR) for FDOT in 2010, the concept was defined as a new concept that would "move transit forward by making transit agencies a partner in the toll road trade. The idea is to create bus lanes with transit agencies as an equity holder or full-owner of the required highway infrastructure... The transit agency share of 'excess' toll revenue would be based on the equity share provided for construction of the BTL facility in a partnership arrangement."

A significant barrier to BTLs at the time was associated with the eligibility of such a project to be funded with Federal Transit Administration (FTA) capital funds, as these represent the most significant source of capital funds for a transit agency to invest. Since that paper was published, a new federal surface transportation authorization has been enacted that provides an opportunity for transit agencies to use federal capital in a managed lane project and share or retain toll revenues collected.

The Moving Ahead for Progress in the 21st Century Act (P.L. 112-141 MAP-21) was signed into law July 6, 2012, funding highway and transit projects and programs for FYs 2013 and 2014. Perhaps the most significant change for BTL funding is found in the revised Section 5309 language on New and Small Starts and a new "Core Capacity Improvement" category of eligibility.

MAP-21 provides three definitions of BRT projects: (1) BRT System Title 49, Section 5302(a)(2); (2) Small Starts Corridor-based BRT project, Section 5309 (a)(3); and (3) New Starts Fixed Guideway BRT project, Section 5309 (a)(4). BRT definitions in numbers 1 and 3 require that a majority of the $B R T$ line operate in a separated right-of-way dedicated to transit. On the other hand, definition 2 only requires that the project emulate rail-fixed guideway services.

The Small Starts Projects definition has been broadened to include not only new fixed guideway capital projects, but also "corridor-based BRT investments." A corridor-based BRT project is one that "is requesting less than $\$ 75$ million in Section 5309 funds and has a total capital cost less than $\$ 250$ million. A corridor-based BRT project is defined as a substantial 
investment in a defined corridor in which the majority does not operate in a separated rightof-way dedicated for transit use during peak periods..."

The change is significant in the researchers' view for the potential of transit agencies becoming financial partners with FDOT or other agencies in the inclusion of substantive transit investments in express lane projects.

\section{Policy Considerations}

When contemplating the incorporation of enhanced public transit into the planning, design, and operation of a managed lane project, arguably the most essential factor for decisionmakers and stakeholders to consider is the strategic objective of the project. If the principal reason for introducing price managed lanes is to finance the highway improvement, then without a strong, demonstrated market for commuter transit, public transportation improvements and financial contributions to capital and operations will likely be considered secondary. That is not to say that this approach is not without merit in getting needed transportation investments accomplished and the resulting ability to provide for future "congestion insurance" and options for users when pricing is implemented.

Conversely, if the prime motivation for considering managed lanes is to relieve congestion and provide immediate transportation alternatives within a corridor or across a network, the entire spectrum of actions available to enhance public transportation should be included in all planning and design. Ideally, in this case, there already exists a market for commuter transit travel. Transit is an integral part of customer choice and considering any design or operating element that boosts the probability of even more successful ridership should be part of the project development discussions.

Clearly and transparently articulating the strategic goal of the managed lane project should provide a clear context for the deliberations over project elements and funding decisions. As mentioned in the section above on Financial Considerations, the statement of purpose of introducing managed lanes can assist in aligning stakeholder expectations with desired project outcomes.

Lastly, on the topic of general policy, is the issue of choice and its relationship to social equity. Researchers observed some relationship between the aggressiveness of a priced lane's operating rules (toll cost, time of day, occupancy requirement) and the extent of priority that is given to public transportation. The more stringent the rules are on the use of the priced lane, the more express bus service and transit funding commitment there was. This could be a result of the level of congestion and the demand for public transportation service, but it raises a relationship that decision-makers may want to include in their thinking on the extent of their commitments to transit in a managed lane project.

\section{Summary of Findings}

There have been scores of managed lane projects implemented around the U.S. and to date a few have included significant commitments to transit beyond running express bus service. Two of Florida's managed lane projects, I-95 and I-595, include some of the more ambitious transit enhancements. 
Transit improvements should be examined in all types of managed lanes-HOVs to express toll lanes-and considered in proportion to the demonstrated or forecast demand for longer distance commuter transit markets, such as those served by commuter or express bus services.

In addition to BRT elements within a corridor being studied for managed lanes, consideration of "off corridor" improvements to facilitate the access to and from the lanes is important.

Funding for the ongoing operation of enhanced transit service along a price-managed facility should become part of a project's plan of finance commensurate with the contribution to the project's strategic goals.

Minor, low-cost actions can make implementation of a managed lane project more conducive to successful transit service. For example, route alignments for existing commuter bus routes should be examined and modified, if necessary, in order to facilitate vehicle ingress and egress from the express lanes.

Revenue sharing between highway agencies and transit organizations is a possibility that could employ price-managed lane projects that include significant public transportation enhancements. MAP-21 eligibility definitions for transit capital create new opportunities for the financing of BRT projects and for revenue sharing implemented in conjunction with express lane projects.

Articulation of a managed lane project's strategic objective and goal early in the project development process can lay a solid foundation for discussions and decisions regarding the appropriate level of public transportation integration into the project. Figure 3-2 provides a framework for making choices and decisions about the extent to which transit considerations can be incorporated into managed lane projects. 


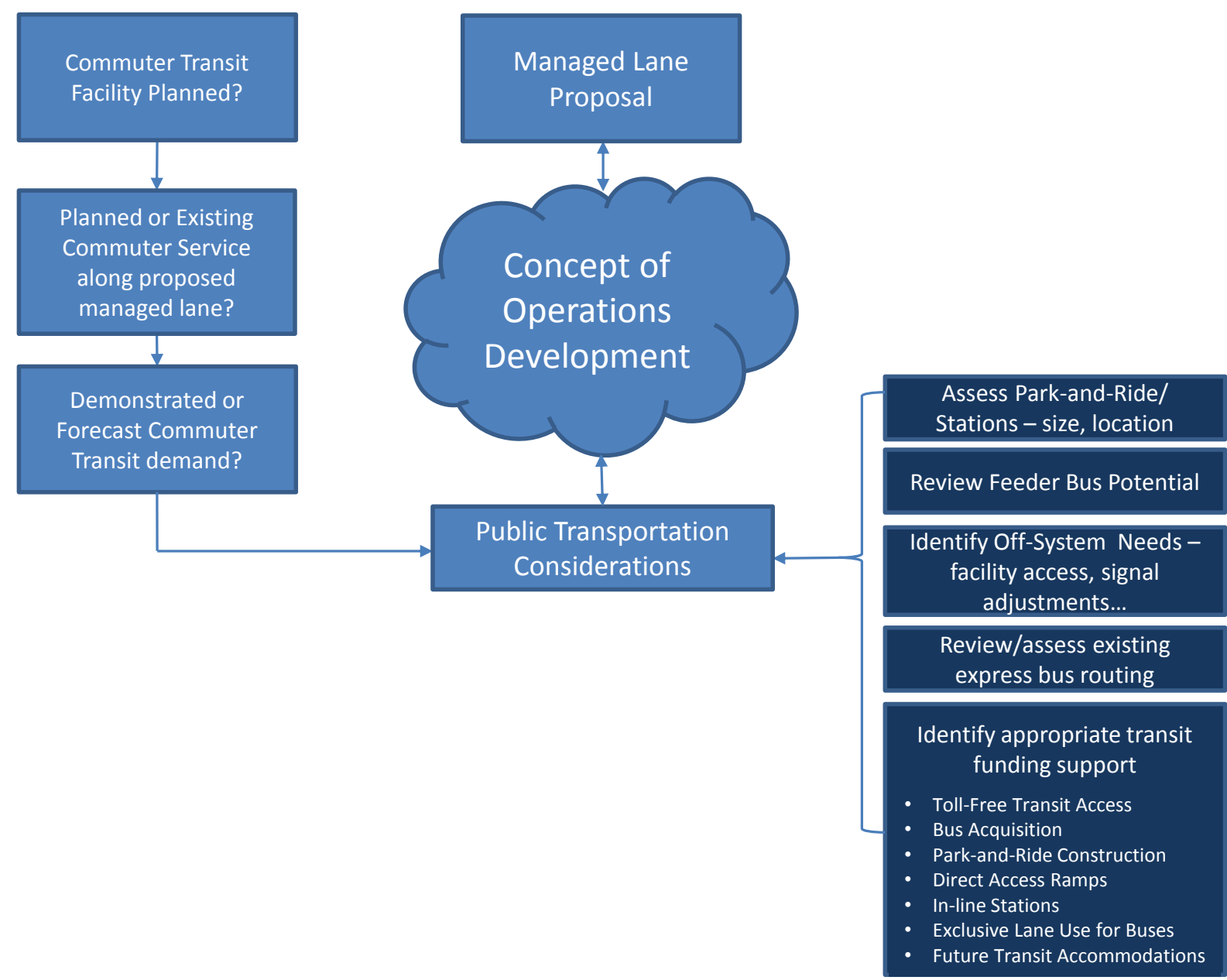

Figure 3-2. A Decision Framework - Transit and Managed Lanes

\section{Recommendations}

If a statewide policy on managed lanes and transit is promulgated, it should be flexible enough with regard to transit to address:

1. The projected market for public transportation in the corridor or on the network

2. That financial commitments and project components to enhance transit service are commensurate with the market potential in a particular corridor or region

3. The accommodation of the various financial constraints and requirements of FDOT, its Districts and Florida's Turnpike Enterprise, local expressway authorities, regional transportation authorities, and transit agencies

4. Recognition of public transportation's contribution to choice and congestion reduction in the corridor.

The principles of the Metro Atlanta policy seem a good starting point for a statewide approach in Florida. They state that all new capacity lanes within limited access corridors shall be managed; mobility shall be guaranteed in managed lanes; lane management relies on eligibility, congestion pricing, and/or accessibility; and each solution is tailored to individual corridor needs. 
Transit agencies with a service area that includes one of the FDOT managed lane studies or projects should undertake a demand forecast for those corridors, if they have not done so recently. This forecast should be at least a sketch planning study that addresses the level of demand for express bus service and passenger volumes, and should include the prospect of the introduction of an express or HOT lane or network. Regional Express Bus and/or BRT plans for urbanized regions of Florida should be considered. Current and future transit markets need to be established not only for a single corridor, but there is also value to assessing the potential ridership implications of a network. This plan could then be overlaid on the express lane plan to see what opportunities emerge. This exercise could assist in finding the answers to the appropriate level of transit integration into these projects.

Transit vehicles should not be required to pay any toll on express lanes and particularly on HOT lanes, as buses are the consummate high-occupancy vehicles.

Investments in integrating transit in a managed lane project should be maximized to a level that is commensurate with public transportation's contribution to choice, level of service, and impact on congestion mitigation in a managed lane corridor. Operating costs need to be included as potential managed lane costs. The contributions that public transportation service will make in the corridor are only sustainable long-term with operating funds to support additional or new service. If transit will be relied upon to make continuous contributions to the corridor, these can only be realized with an ongoing funding commitment.

Consideration should be given to the creation and adoption of guidelines on how to plan, implement, operate, and maintain managed lane projects with substantive transit components. The Decision Framework presented in Figure 3-2 addresses an approach for initial project design elements and a few operational policies; it does not deal with the ongoing financial issues associated with transportation investment. Again, the principle of striking the appropriate balance between project policy motivation and ongoing operating commitments and responsibilities should be core to these guidelines. Another guiding principle to be considered is that agency responsibility should be assigned based on the activity's relationship to an agency's core competency. The assignment of responsibility should be divorced from financial obligation for a specific activity. For example, station maintenance may best be performed by a transit agency because of the skills of its labor force, but could be the financial responsibility of the entity collecting toll revenue.

There should be early and wide agreement on the strategic objective of a particular managed lane proposal. Many detailed decisions on a project can be made easier if there is general consensus on a project's main goal.

At a minimum, a sketch level ridership forecast should be required prior to the development of a facility Concept of Operations if transit integration is contemplated. Consideration should be given to adopting a standard approach to assessing the transit ridership forecasts for service provided in conjunction with managed lanes. If similar modeling and forecasting methods were used, FDOT would be in a better position to evaluate transit investment decisions from project to project and across regions of Florida. 


\section{Appendix A \\ Congestion Pricing Projects Open to Traffic in the United States, 2011}

\section{Sources: GAO Report 12-119, Texas Transportation Institute - Managed Lanes}

\begin{tabular}{|c|c|c|c|c|c|c|c|c|}
\hline \multicolumn{9}{|c|}{ Cape Coral and Midpoint Memorial Bridges - Lee County, FL - FY 2000} \\
\hline $\begin{array}{l}\text { No. Facilities/ } \\
\text { Miles }\end{array}$ & $\begin{array}{l}\text { Project } \\
\text { Type }\end{array}$ & Pricing Type & Toll Rates & $\begin{array}{l}\text { Funding } \\
\text { Recipient }\end{array}$ & Project Type & $\begin{array}{l}\text { Value Pricing } \\
\text { Pilot Program }\end{array}$ & $\begin{array}{l}\text { Pricing } \\
\text { Type }\end{array}$ & Grant \\
\hline 2 bridges & Bridge & Peak-period & $\begin{array}{l}\$ 1.50-\$ 6.00+ \\
\text { charge per axle }\end{array}$ & $\begin{array}{l}\text { Lee County, } \\
\text { FL }\end{array}$ & $\begin{array}{l}\text { Managed } \\
\text { facility }\end{array}$ & Priced lanes & ETL/VPP & $\$ 2,410,400$ \\
\hline Project & \multicolumn{8}{|c|}{$\begin{array}{l}\text { Study priced queue jump (a facility that can be used to bypass points on the transportation network where congestion } \\
\text { is particularly severe and occurs in a predictable pattern), variable pricing of heavy vehicles, and variable tolls for } \\
\text { heavy vehicles in Lee County, FL, since August } 1998\end{array}$} \\
\hline Status & \multicolumn{8}{|c|}{ Study completed and project implemented in December 2003} \\
\hline Toll Schedule & \multicolumn{8}{|c|}{$\begin{array}{l}\text { - Tolls vary by time of day } \\
\text { - Tolls are levied electronically } \\
\text { - Tolls are part of Lee County's ETC system }\end{array}$} \\
\hline
\end{tabular}

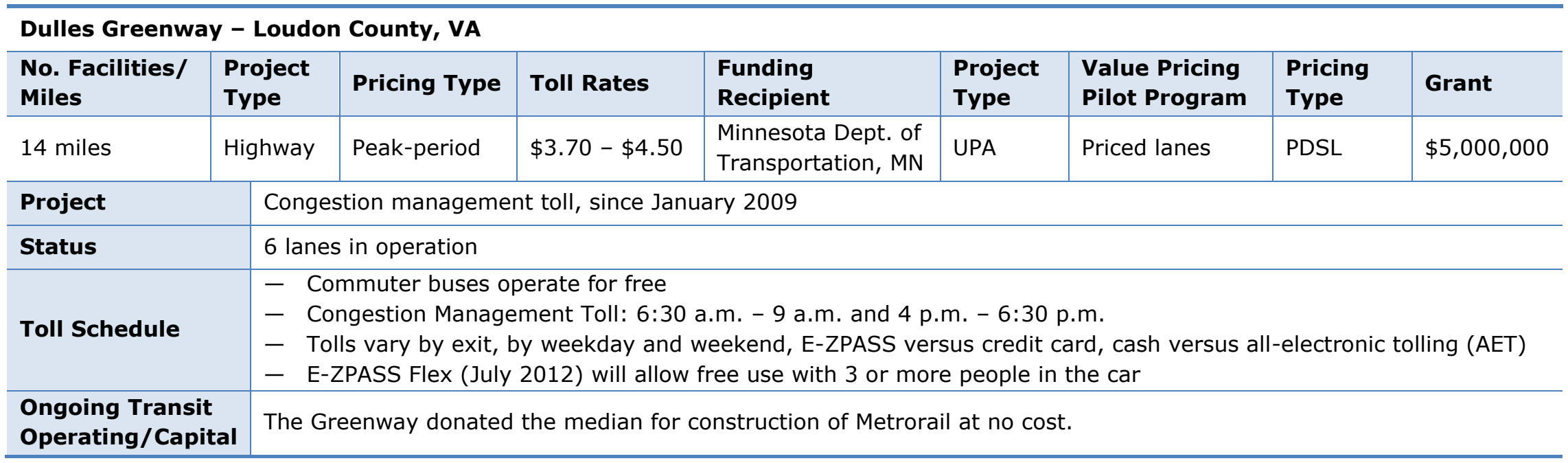




\begin{tabular}{|c|c|c|c|c|c|c|c|c|}
\hline \multicolumn{9}{|c|}{ I-10 and US 290 - Houston, TX - FY 2000} \\
\hline $\begin{array}{l}\text { No. Facilities/ } \\
\text { Miles }\end{array}$ & $\begin{array}{l}\text { Project } \\
\text { Type }\end{array}$ & Pricing Type & Toll Rates & $\begin{array}{l}\text { Funding } \\
\text { Recipient }\end{array}$ & Project Type & $\begin{array}{l}\text { Value Pricing } \\
\text { Pilot Program }\end{array}$ & $\begin{array}{l}\text { Pricing } \\
\text { Type }\end{array}$ & Grant \\
\hline $\begin{array}{l}\text { I-10: } 12 \text { miles } \\
\text { US 290: } 15 \text { miles }\end{array}$ & HOT lane & $\begin{array}{l}\text { Dynamic } \\
\text { peak-period }\end{array}$ & $\begin{array}{l}\$ 0.30-\$ 1.60 \\
\$ 2.00 \text { for } \mathrm{HOV}\end{array}$ & $\begin{array}{l}\text { Houston, } \\
\text { TX }\end{array}$ & Managed lanes & System-wide & HOT & $\$ 2,436,000$ \\
\hline Project & \multicolumn{8}{|c|}{$\begin{array}{l}\text { Examine Houston's five HOV lane facilities with a goal of developing an implementation plan for those HOT lanes, } \\
\text { including expanding current HOT activities on Northwest Freeway and adding tolling to the other four HOV lanes, to } \\
\text { develop a network of HOT lanes on three radial corridors in Houston, TX, since January } 1998\end{array}$} \\
\hline Status & \multicolumn{8}{|c|}{$\begin{array}{l}\text { Original I-10 study completed and pre-implementation funds awarded in } 2004 . \text { US } 290 \text { study completed. Toll } \\
\text { revenues from several hundred vehicles each day pay for all program costs. }\end{array}$} \\
\hline Toll Schedule & \multicolumn{8}{|c|}{$\begin{array}{l}\text { - Two lanes in each direction between SH } 6 \text { and IH } 610 \text { replace the single, reversible HOV lane } \\
\text { - } 12 \text { miles of roadway, separated from the main lanes by flexible "candlestick" barriers } \\
\text { - } \text { Primarily serves mass transit and HOV needs during peak hours, with any unused lane capacity made available to } \\
\text { single drivers for a toll } \\
\text { - } \text { Serves as an all-electronic tollway for all vehicles (except mass transit) during all other times } \\
\text { - } \text { Uses dynamic tolling to keep traffic moving } \\
\text { - Harris County Constables enforce lawful use of the managed lanes } \\
\text { - During rush hours, the minimum requirement raises to } 3+\text { occupants on US } 290 \\
\text { - } \text { QuickRide is a program that allows vehicles with } 2 \text { occupants to continue driving the HOV during these times for } \\
\text { just } \$ 2 \text { each way. Times vary per freeway, and registration is required: I- } 10 \mathrm{~W}-24 \times 7=2+/ \text { US } 290 \mathrm{~W}-6: 45- \\
8: 00 \text { a.m. }=3+\text { Inbound }\end{array}$} \\
\hline $\begin{array}{l}\text { Ongoing Transit } \\
\text { Operating/Capital }\end{array}$ & \multicolumn{8}{|c|}{$\begin{array}{l}\text { The tolls collected from the I-10 Katy Managed Lanes and all Harris County Toll Road Authority (HCTRA) managed toll } \\
\text { roads go right back into Harris County, and help manage and maintain the system of roadways, as well as help fund } \\
\text { the upkeep of other county roads. Metropolitan Transit Authority of Harris County (METRO) has a } 1 \% \text { sales and use } \\
\text { tax imposed within METRO's service area for transit activities. }\end{array}$} \\
\hline $\begin{array}{l}\text { Transit } \\
\text { Infrastructure }\end{array}$ & \multicolumn{8}{|c|}{$\begin{array}{l}\text { Park \& Ride service is for long-distance commuting. METRO's } 29 \text { Park \& Ride lots provide bus service to key } \\
\text { destinations in the service area. One-way fare falls into four zones based on the distance a bus travels. }\end{array}$} \\
\hline
\end{tabular}




\begin{tabular}{|c|c|c|c|c|c|c|c|c|c|}
\hline \multicolumn{10}{|c|}{ I-15 - Salt Lake City, UT } \\
\hline $\begin{array}{l}\text { No. Facilities/ } \\
\text { Miles }\end{array}$ & $\begin{array}{l}\text { Prc } \\
\text { Ty }\end{array}$ & $\begin{array}{l}\text { ject } \\
\text { pe }\end{array}$ & Pricing Type & Toll Rates & $\begin{array}{l}\text { Funding } \\
\text { Recipient }\end{array}$ & Project Type & $\begin{array}{l}\text { Value Pricing } \\
\text { Pilot Program }\end{array}$ & Pricing Type & Grant \\
\hline 40 miles & & T lane & Dynamic & $\$ 0.25-\$ 1.00$ & $\begin{array}{l}\text { Salt Lake } \\
\text { City, UT }\end{array}$ & Express lanes & & HOT & \\
\hline Project & & \multicolumn{8}{|c|}{ I-15 HOT lanes, since September 2006} \\
\hline Status & & \multicolumn{8}{|c|}{ Dynamic pricing in effect } \\
\hline Toll Schedule & & \multicolumn{8}{|c|}{$\begin{array}{l}\text { - Express lanes are divided into four payment zones with overhead signs that show the price to travel in each zone, } \\
\text { using the supply-and-demand concept } \\
\text { - An algorithm adjusts the price to drive in each zone based on traffic conditions, with costs highest during peak } \\
\text { traffic } \\
- \text { Express Pass costs } \$ 8.75 \\
- \text { Carpoolers given first priority (free) } \\
- \text { Solo drivers may pay a fee to use remaining capacity } \\
\text { - Maintain } 55 \mathrm{mph}\end{array}$} \\
\hline $\begin{array}{l}\text { Ongoing Transit } \\
\text { Operating/Capi }\end{array}$ & & \multicolumn{8}{|c|}{ Tolls must be used to operate and maintain the Express Lanes } \\
\hline
\end{tabular}




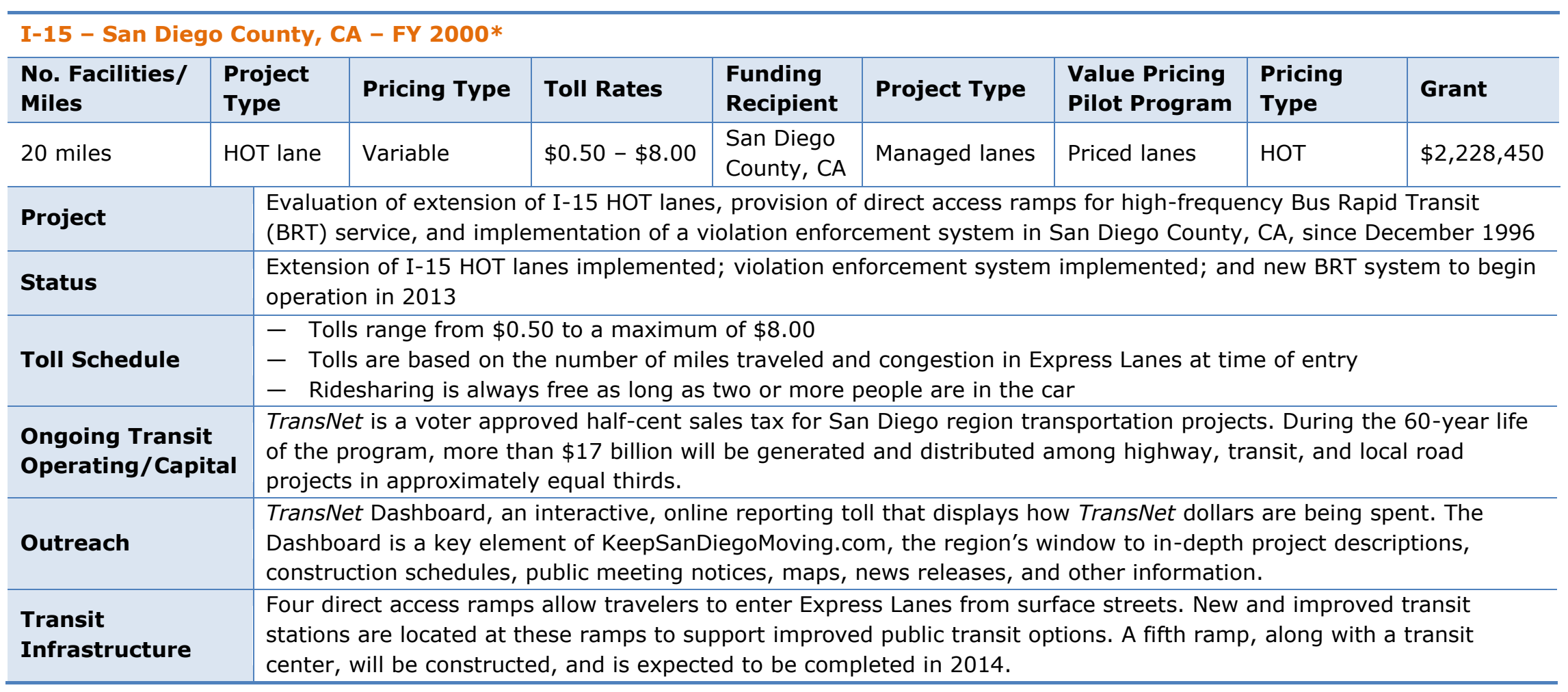

*Discussed in detail in the report. 


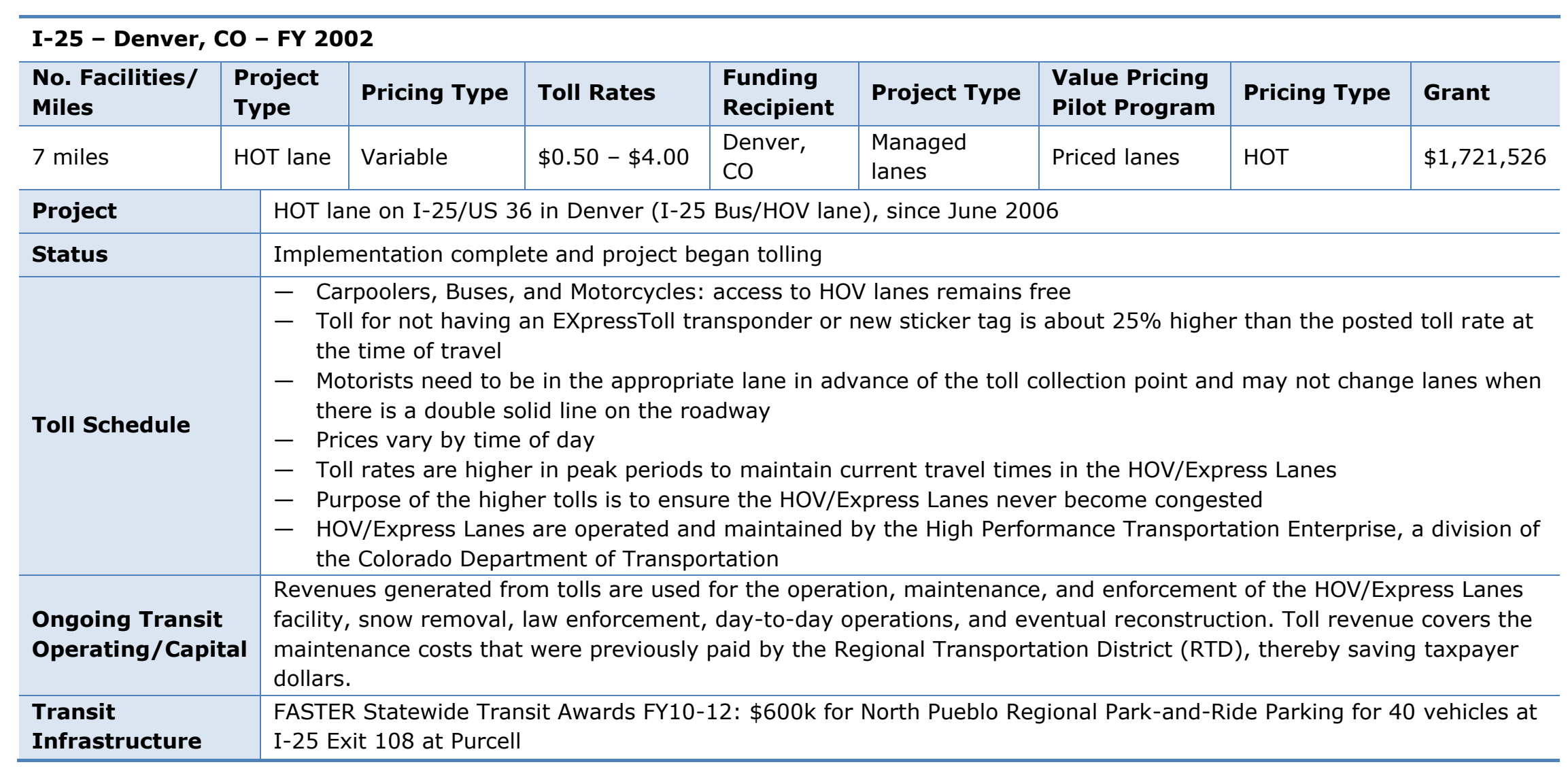




\begin{tabular}{|c|c|c|c|c|c|c|c|c|c|}
\hline \multicolumn{10}{|c|}{ I-35W - Minneapolis-St. Paul, MN - FY 2008} \\
\hline $\begin{array}{l}\text { No. Facilities/ } \\
\text { Miles }\end{array}$ & \multicolumn{2}{|c|}{$\begin{array}{l}\text { Project } \\
\text { Type }\end{array}$} & Pricing Type & Toll Rates & $\begin{array}{l}\text { Funding } \\
\text { Recipient }\end{array}$ & $\begin{array}{l}\text { Project } \\
\text { Type }\end{array}$ & $\begin{array}{l}\text { Value Pricing } \\
\text { Pilot Program }\end{array}$ & $\begin{array}{l}\text { Pricing } \\
\text { Type }\end{array}$ & Grant \\
\hline 16 miles & \multicolumn{2}{|c|}{ HOT lane } & Dynamic & $\$ 0.25-\$ 8.00$ & $\begin{array}{l}\text { Minnesota Dept. of } \\
\text { Transportation, MN }\end{array}$ & UPA & Priced lanes & PDSL & $\$ 5,000,000$ \\
\hline \multicolumn{2}{|l|}{ Project } & \multicolumn{8}{|c|}{$\begin{array}{l}\text { UPA to study MN Innovative Choices for Congestion relief, using priced dynamic shoulder lanes (PDSL) on northbound } \\
\text { portion of I-35W, since September } 2009\end{array}$} \\
\hline \multicolumn{2}{|l|}{ Status } & \multicolumn{8}{|c|}{ Study completed and project implemented } \\
\hline Toll Schedule & & \multicolumn{8}{|c|}{$\begin{array}{l}\text { - Transit buses, carpools, and motorcycles can use the MnPASS Express Lanes for free } \\
\text { - } \$ 1.50 \text { monthly lease per transponder } \\
\text { - Price for one section of road varies: } \$ 0.25 \text { to } \$ 8.00 \\
\text { - Average toll during peak periods is } \$ 1.00 \text { to } \$ 4.00\end{array}$} \\
\hline \multicolumn{2}{|c|}{$\begin{array}{l}\text { Ongoing Transit } \\
\text { Operating/Capital }\end{array}$} & \multicolumn{8}{|c|}{$\begin{array}{l}\text { Fees will pay for operation of the MnPASS Express Lanes. Excess revenues will be used to improve transit and other } \\
\text { transportation needs. }\end{array}$} \\
\hline
\end{tabular}


I-85 - Atlanta, GA*

\begin{tabular}{|c|c|c|c|c|c|c|c|c|c|}
\hline $\begin{array}{l}\text { No. Facilities/ } \\
\text { Miles }\end{array}$ & \multicolumn{2}{|c|}{$\begin{array}{l}\text { Project } \\
\text { Type }\end{array}$} & Pricing Type & Toll Rates & $\begin{array}{l}\text { Funding } \\
\text { Recipient }\end{array}$ & Project Type & $\begin{array}{l}\text { Value Pricing } \\
\text { Pilot Program }\end{array}$ & Pricing Type & Grant \\
\hline 15.5 miles & \multicolumn{2}{|c|}{ HOT lane } & Dynamic & $\$ 1.55-\$ 13.95$ & & & & & \\
\hline \multicolumn{2}{|l|}{ Project } & \multicolumn{8}{|c|}{ Dynamic pricing } \\
\hline \multicolumn{2}{|l|}{ Status } & \multicolumn{8}{|c|}{ Operational in October 2011} \\
\hline Toll Schedule & & \multicolumn{8}{|c|}{$\begin{array}{l}\text { - Express lanes are open } 24 \text { hours a day } \\
\text { - Toll-exempt vehicle (registration required): carpools with } 3 \text { or more occupants, motorcycles, transit and } \\
\text { emergency vehicles, and alternative fuel vehicles (AFV) with the proper AFV license plate } \\
\text { - Price to use the lanes changes to keep traffic moving even during rush hours } \\
\text { - As demand increases, the tolls rise to ensure the optimal number of cars is moving through the lanes } \\
\text { - Estimated average trip length that ranges between } 6 \text { and } 7 \text { miles may result in a typical toll price ranging from } \\
\$ 0.60 \text { to } \$ 6.00 \text { per trip depending on congestion } \\
\text { - It is estimated that over } 90 \% \text { of customers will play less than } \$ 5.00 \text { for their HOT lane trip } \\
\text { - Approximately } 25 \% \text { of customers will use the HOT lane for free, including passenger vehicles with } 3 \text { or more } \\
\text { occupants, transit, motorcycles, and other qualified vehicles }\end{array}$} \\
\hline $\begin{array}{l}\text { Ongoing Transit } \\
\text { Operating/Capita }\end{array}$ & & \multicolumn{8}{|c|}{$\begin{array}{l}\text { A portion of Phase I funds will be used to build } 2 \text { new Park-and-Ride facilities, which will create } 1,900 \text { additional } \\
\text { parking spaces for transit users; to purchase } 36 \text { new commuter coach buses that will support } 7 \text { routes serving the } \\
\text { I- } 85 \text { project corridor; and will also provide for enhanced Highway Emergency Response Operators (HERO) incident } \\
\text { management services in the corridor. }\end{array}$} \\
\hline Outreach & & \multicolumn{8}{|c|}{$\begin{array}{l}\text { A robust public outreach and education program is ongoing. As part of the National Environmental Protection Act } \\
\text { (NEPA) process, about } 600 \text { people attended and had the opportunity to provide feedback at } 8 \text { public information open } \\
\text { houses and a public hearing open house in } 2009 \text {. Participant feedback included concerns about equity and } \\
\text { enforcements, the effects of revised occupancy requirements on } 2 \text {-person carpoolers, and an interest in the } \\
\text { technology the project will bring to the region. In addition, } 6 \text { focus groups were conducted with single-occupant } \\
\text { drivers and carpoolers, as well as a survey of more than } 700 \text { carpoolers in the I- } 85 \text { region. One-on-one briefings with } \\
\text { stakeholders, legislators, and the media also took place-and a project website for the public has been established at } \\
\text { www.dot.ga.gov/I85HOTLanes. }\end{array}$} \\
\hline & & \multicolumn{8}{|c|}{$\begin{array}{l}\text { Expansion of transit in the I-85 corridor is a major component of this project. In addition, the metro Atlanta region's } \\
\text { Concept } 3 \text { Transit Vision includes expanded rail and BRT in the corridor that could be part of a future expanded HOT } \\
\text { network. Funds generated will be used to defray the costs of construction, operations, and maintenance of the lanes. } \\
\text { Long-term revenue allocation is being studied, and a decision about future excess revenues will be made later in the } \\
\text { project process. }\end{array}$} \\
\hline
\end{tabular}

* Discussed in detail in the report. 


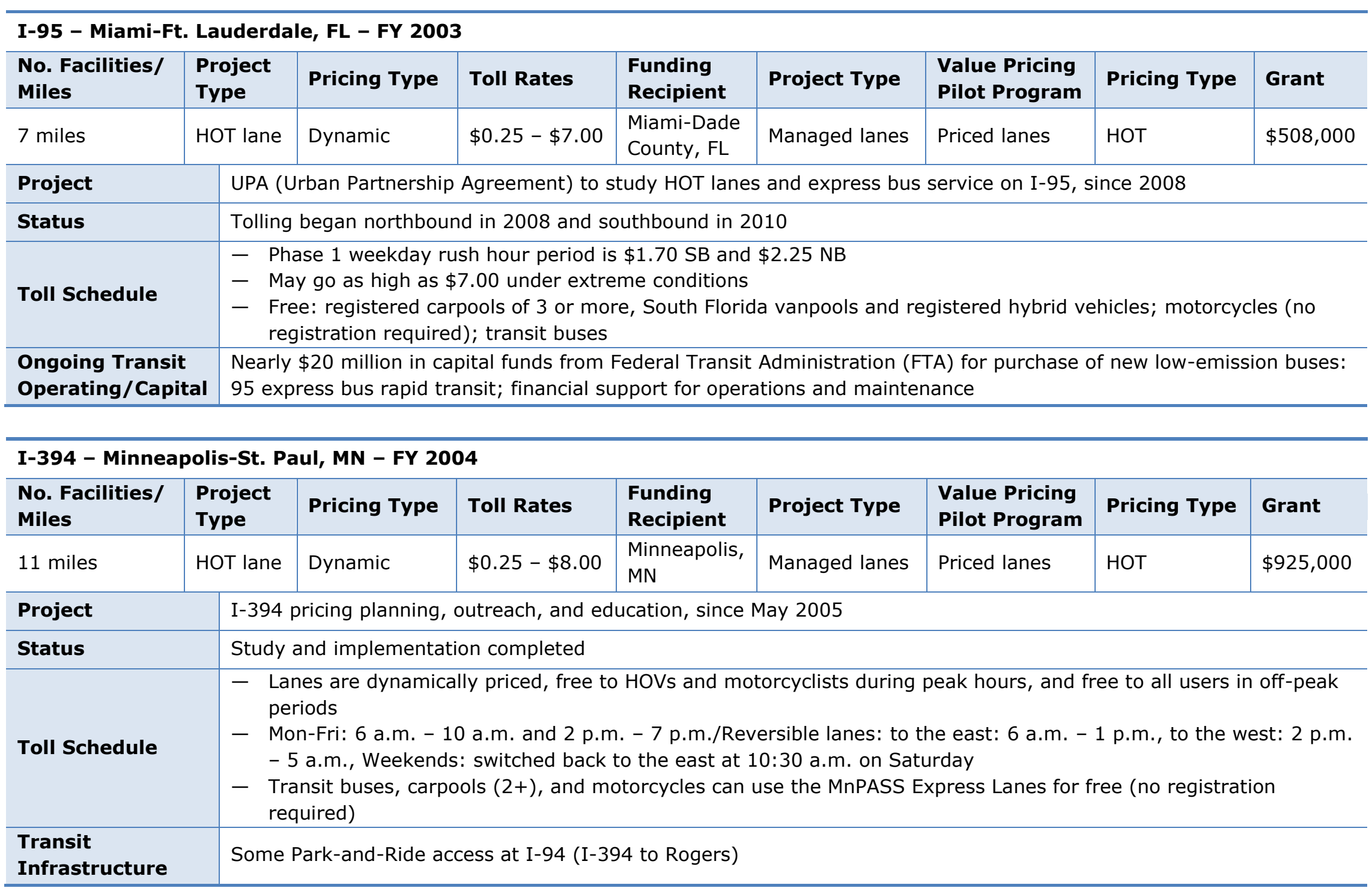




\begin{tabular}{|c|c|c|c|c|c|c|c|c|c|}
\hline \multicolumn{10}{|c|}{ I-680 - Alameda and Santa Clara Counties, CA - FY 2004} \\
\hline $\begin{array}{l}\text { No. Facilities/ } \\
\text { Miles }\end{array}$ & & $\begin{array}{l}\text { oject } \\
\text { pe }\end{array}$ & Pricing Type & Toll Rates & $\begin{array}{l}\text { Funding } \\
\text { Recipient }\end{array}$ & $\begin{array}{l}\text { Project } \\
\text { Type }\end{array}$ & $\begin{array}{l}\text { Value Pricing } \\
\text { Pilot Program }\end{array}$ & Pricing Type & Grant \\
\hline 14 miles & $\mathrm{HO}$ & T lane & Dynamic & $\$ 0.30-\$ 1.75$ & $\begin{array}{l}\text { Alameda } \\
\text { County, CA }\end{array}$ & $\begin{array}{l}\text { Managed } \\
\text { lanes }\end{array}$ & Priced lanes & НОТ & $\$ 1,664,000$ \\
\hline \multicolumn{2}{|l|}{ Project } & \multicolumn{8}{|c|}{ I-680 SMART carpool lanes, since September 2010} \\
\hline \multicolumn{2}{|l|}{ Status } & \multicolumn{8}{|c|}{ SMART carpool lanes operational } \\
\hline \multicolumn{2}{|l|}{ Toll Schedule } & \multicolumn{8}{|c|}{$\begin{array}{l}\text { - Regular carpools ( } 2 \text { or more), motorcycles, and transit buses travel free with no toll tag required } \\
\text { - Minimum toll during AM commute is } \$ 1.00, \text { with off-peak minimum of } \$ 0.30 \\
\text { - Operation is fully electronic } \\
\text { - Toll costs vary based on real-time traffic levels in the express Lane to ensure traffic in the lane continues to flow } \\
\text { - Express lane operates Monday to Friday from } 5 \text { a.m. to } 8 \text { p.m. At nights and on weekends, the lane is open to all } \\
\text { drivers }\end{array}$} \\
\hline \multicolumn{2}{|c|}{$\begin{array}{l}\text { Ongoing Transit } \\
\text { Operating/Capital }\end{array}$} & \multicolumn{8}{|c|}{$\begin{array}{l}\text { Toll revenue will pay for operating and maintaining the lane, for transit service on the I-680 corridor, and for building } \\
\text { other carpool lanes or express lanes in the I- } 680 \text { corridor, including a future project on northbound I- } 680 \text {. }\end{array}$} \\
\hline \multicolumn{10}{|c|}{ Lake of the Ozarks Bridge - Lake Ozark, MO } \\
\hline $\begin{array}{l}\text { No. Facilities/ } \\
\text { Miles }\end{array}$ & \multicolumn{2}{|c|}{$\begin{array}{l}\text { Project } \\
\text { Type }\end{array}$} & Pricing Type & Toll Rates & $\begin{array}{l}\text { Funding } \\
\text { Recipient }\end{array}$ & Project Type & $\begin{array}{l}\text { Value Pricing } \\
\text { Pilot Program }\end{array}$ & Pricing Type & Grant \\
\hline Bridge & & & & $\$ 2.00-\$ 3.00$ & & & & & \\
\hline \multicolumn{2}{|l|}{ Toll Schedule } & \multicolumn{8}{|c|}{$\begin{array}{l}\text { - Toll Rates In Season: Passenger car, van, pickup, or motorcycle - } \$ 3.00 ; \text { Toll Rates Out of Season: Passenger car, } \\
\text { van, pickup, or motorcycle }-\$ 2.00\end{array}$} \\
\hline \multicolumn{2}{|c|}{$\begin{array}{l}\text { Ongoing Transit } \\
\text { Operating/Capital }\end{array}$} & \multicolumn{8}{|c|}{$\begin{array}{l}\text { Funds generated by tolls are used to repay the nearly } \$ 43 \text { million in bonds needed to finance the planning, } \\
\text { development, and construction of the bridge system. }\end{array}$} \\
\hline
\end{tabular}




\begin{tabular}{|c|c|c|c|c|c|c|c|c|c|}
\hline \multicolumn{10}{|c|}{ MD-200 (Inter-County Connector) - Montgomery County, MD } \\
\hline $\begin{array}{l}\text { No. Facilities/ } \\
\text { Miles }\end{array}$ & & $\begin{array}{l}\text { oject } \\
\text { pe }\end{array}$ & Pricing Type & Toll Rates & $\begin{array}{l}\text { Funding } \\
\text { Recipient }\end{array}$ & Project Type & $\begin{array}{l}\text { Value Pricing } \\
\text { Pilot Program }\end{array}$ & Pricing Type & Grant \\
\hline 18.8 miles & Hig & ghway & Peak period & $\$ 0.60-\$ 1.45$ & $\begin{array}{l}\text { Montgomery } \\
\text { County, MD }\end{array}$ & & & & \\
\hline Project & \multicolumn{9}{|c|}{$\begin{array}{l}\text { The Inter-county Connector (ICC)/MD } 200 \text { is Maryland's first all-electronic toll road where tolls are collected at } \\
\text { highway speed as motorists drive under tolling structures. }\end{array}$} \\
\hline Toll Schedule & \multicolumn{9}{|c|}{$\begin{array}{l}\text { - Tolls vary to help manage traffic volumes, with a higher toll charged during peak hours and a lower toll charged } \\
\text { during off-peak and overnight hours } \\
\text { - Tolls are higher during peak travel times (Monday - Friday, } 6 \text { a.m. - } 9 \text { a.m. and } 4 \text { p.m. - } 7 \text { p.m.) and reduced } \\
\text { during off-peak and overnight pricing periods } \\
\text { - Peak Period ( } \$ 0.25 / \text { mile }-\$ 0.35 / \text { mile); Off-Peak Period }(\$ 0.20 / \text { mile }-\$ 0.30 / \text { mile); Overnight Period ( } \$ 0.10 / \text { mile } \\
-\$ 0.30 / \text { mile) }\end{array}$} \\
\hline $\begin{array}{l}\text { Ongoing Transi } \\
\text { Operating/Capi }\end{array}$ & \multicolumn{9}{|c|}{ Tolling provides funds for financing, operating, and maintaining a large transportation project like the ICC. } \\
\hline $\begin{array}{l}\text { Transit } \\
\text { Infrastructure }\end{array}$ & & \multicolumn{8}{|c|}{$\begin{array}{l}\text { The ICC provides access to Metrorail, MARC Train Service, BWI Marshall Airport, local transit services, and MTA's } \\
\text { Commuter Bus Service. The Maryland Transit Administration (MTA) operates high-quality, tour-style commuter buses } \\
\text { along express routes, linking key employment and activity centers along the I-270 \& I-95 corridors. }\end{array}$} \\
\hline
\end{tabular}




\begin{tabular}{|c|c|c|c|c|c|c|c|c|}
\hline \multicolumn{9}{|c|}{ New Jersey Turnpike - New Jersey, US - FY 2001} \\
\hline $\begin{array}{l}\text { No. Facilities/ } \\
\text { Miles }\end{array}$ & $\begin{array}{l}\text { Project } \\
\text { Type }\end{array}$ & Pricing Type & Toll Rates & $\begin{array}{l}\text { Funding } \\
\text { Recipient }\end{array}$ & Project Type & $\begin{array}{l}\text { Value Pricing } \\
\text { Pilot Program }\end{array}$ & $\begin{array}{l}\text { Pricing } \\
\text { Type }\end{array}$ & Grant \\
\hline 148 miles & Highway & Peak-period & $\$ 0.90-\$ 9.05$ & $\begin{array}{l}\text { New Jersey } \\
\text { statewide }\end{array}$ & $\begin{array}{l}\text { Managed } \\
\text { facility }\end{array}$ & Priced tollway & VPP & $\$ 477,468$ \\
\hline Project & \multicolumn{8}{|c|}{ Evaluate variable tolls on New Jersey Turnpike, since 2000} \\
\hline Status & \multicolumn{8}{|c|}{ Evaluation completed and variable tolls implemented on the New Jersey Turnpike } \\
\hline Toll Schedule & \multicolumn{8}{|c|}{$\begin{array}{l}\text { - Program provided for tolls that were } 12 \text { percent higher during peak traffic hours than during off-peak periods for } \\
\text { ETC } \\
\text { - Price differential is scheduled to increase in a phased manner over several years } \\
\text { - Peak periods are 7:00 to 9:00 a.m. and 4:30 to 6:30 p.m., Monday through Friday, and all day Saturday and } \\
\text { Sunday } \\
\text { - Discount Programs for registered: Senior Citizen, Green Pass (45 mpg + SULEV), Off Peak, Off Peak + Pkwy } \\
\text { Truck, Turnpike Truck, Florence Resident, GSP Trailer, and multiple Bus, including New Jersey Turnpike Commuter } \\
\text { Bus Discount, New Jersey Transit Bus Discount, Garden State Parkway Commuter Bus Discount, and School Bus } \\
\text { Discount }\end{array}$} \\
\hline $\begin{array}{l}\text { Transit } \\
\text { Infrastructure }\end{array}$ & \multicolumn{8}{|c|}{$\begin{array}{l}\text { Commuter lots adjacent to the turnpike and in some service areas provide access to express bus service and are } \\
\text { identified on the turnpike map to enable trip planning. }\end{array}$} \\
\hline
\end{tabular}




\begin{tabular}{|c|c|c|c|c|c|c|c|c|c|}
\hline \multicolumn{10}{|c|}{ New York Metro Area - New York/New Jersey, US - FY 2001} \\
\hline $\begin{array}{l}\text { No. Facilities/ } \\
\text { Miles }\end{array}$ & & ject & Pricing Type & Toll Rates & $\begin{array}{l}\text { Funding } \\
\text { Recipient }\end{array}$ & Project Type & $\begin{array}{l}\text { Value Pricing } \\
\text { Pilot Program }\end{array}$ & $\begin{array}{l}\text { Pricing } \\
\text { Type }\end{array}$ & Grant \\
\hline $\begin{array}{l}4 \text { bridges } \\
2 \text { tunnels }\end{array}$ & & $\begin{array}{l}\text { lge \& } \\
\text { inel }\end{array}$ & Peak-period & $\$ 4.00-\$ 8.00$ & $\begin{array}{l}\text { New Jersey } \\
\text { statewide }\end{array}$ & $\begin{array}{l}\text { Managed } \\
\text { facility }\end{array}$ & Priced tollway & XBL/HOT & $\$ 1,680,706$ \\
\hline \multicolumn{2}{|l|}{ Project } & \multicolumn{8}{|c|}{$\begin{array}{l}\text { Evaluate variable tolls on river crossings and examine feasibility } \\
\text { express bus/HOT lane in Lincoln Tunnel, since March } 2001\end{array}$} \\
\hline \multicolumn{2}{|l|}{ Status } & \multicolumn{8}{|c|}{$\begin{array}{l}\text { Evaluation completed and study completed: "Lincoln Tunnel HOT Lane Feasibility Study, The Port Authority of NY \& } \\
\text { NJ, December 2009, Final Report" }\end{array}$} \\
\hline \multicolumn{2}{|l|}{ Toll Schedule } & \multicolumn{8}{|c|}{$\begin{array}{l}\text { - Peak Hours: Weekdays: } 6-10 \text { a.m., } 4-8 \text { p.m. / Sat \& Sun: } 11 \text { a.m. }-9 \text { p.m. } \\
- \text { Green Pass customers }(45 \mathrm{mpg}+\text { SULEV) } \$ 4.00 \text { toll during off-peak hours } \\
- \text { Carpool customers } \$ 3.50 \text { per vehicle at all hours } \\
-\quad \text { Discounted off-peak toll two axles and single rear wheels }=\$ 7.50 \\
-\quad \$ 8.7 \text { billion Mass Transit Tunnel (MTT) project }(2009)-\text { FTA+ARRA+FHWA funding }\end{array}$} \\
\hline \multicolumn{2}{|c|}{$\begin{array}{l}\text { Ongoing Transit } \\
\text { Operating/Capital }\end{array}$} & \multicolumn{8}{|c|}{$\begin{array}{l}\text { The current list of TRANSCOM (regional transportation management) members and their percentage shares of } \\
\text { contributions toward TRANSCOM's budget are as follows: } 15.69 \% \text {-Port Authority, NJDOT, NYSDOT; } 7.84 \%-M T A, \text { B\&T, } \\
\text { NYCDOT, NJTA; 3.93\%-NJT, PATH, NYCT, Connecticut DOT, NYSTA; } 1.96 \%-N Y S B A\end{array}$} \\
\hline \multicolumn{10}{|c|}{ Pocahontas Parkway - Richmond, VA } \\
\hline $\begin{array}{l}\text { No. Facilities/ } \\
\text { Miles }\end{array}$ & & $\begin{array}{l}\text { oject } \\
\text { pe }\end{array}$ & Pricing Type & Toll Rates & \begin{tabular}{l|} 
Funding \\
Recipient
\end{tabular} & Project Type & $\begin{array}{l}\text { Value Pricing } \\
\text { Pilot Program }\end{array}$ & Pricing Typ & Grant \\
\hline 8.8 miles & & hway & Peak-period & $\$ 2.75-\$ 3.00$ & & & & & \\
\hline Project & & \multicolumn{8}{|c|}{ Peak-period pricing } \\
\hline Status & & \multicolumn{8}{|c|}{ Operational in January 2011} \\
\hline Toll Schedule & & \multicolumn{8}{|c|}{$\begin{array}{l}\text { - In 2006, VDOT initiated a 99-year lease with Transurban to manage and maintain the road } \\
- \text { Commuting hours: } 6-9 \text { a.m. and } 3-6 \text { p.m. weekdays }=\$ 3.00 \\
- \text { All other weekday times and weekends }=\$ 2.75\end{array}$} \\
\hline
\end{tabular}




\begin{tabular}{|c|c|c|c|c|c|c|c|c|c|}
\hline \multicolumn{10}{|c|}{ San Francisco-Oakland Bay Bridge - San Francisco Bay Area, CA } \\
\hline $\begin{array}{l}\text { No. Facilities / } \\
\text { Miles }\end{array}$ & $\begin{array}{l}\text { Proj } \\
\text { Typ }\end{array}$ & $\begin{array}{l}\text { ject } \\
\text { pe }\end{array}$ & Pricing Type & Toll Rates & $\begin{array}{l}\text { Funding } \\
\text { Recipient }\end{array}$ & Project Type & $\begin{array}{l}\text { Value Pricing } \\
\text { Pilot Program }\end{array}$ & Pricing Type & Grant \\
\hline 8 miles & Brid & dge & Peak period & $\$ 2.50-\$ 6.00$ & & & & & \\
\hline \multicolumn{2}{|l|}{ Project } & \multicolumn{8}{|c|}{ Congestion management toll, since January 2009} \\
\hline \multicolumn{2}{|l|}{ Status } & \multicolumn{8}{|c|}{ Peak-period pricing operational July 2010} \\
\hline Toll Schedule & \multicolumn{9}{|c|}{$\begin{array}{l}\text { - Tolls are collected manually or electronically in one direction on each of the state-owned bridges, according to a } \\
\text { toll schedule established by Bay Area Toll Authority (BATA) and the California legislature } \\
\text { - For the typical automobile, a } \$ 5 \text { toll is collected - a } \$ 1 \text { base toll, } \$ 1 \text { for Regional Measure } 2 \text {, and a } \$ 3 \text { seismic } \\
\text { retrofit surcharge } \\
\text { - Toll schedule for the San Francisco-Oakland Bay Bridge is different during weekdays when congestion pricing is in } \\
\text { effect } \\
\text { - Multi-axle vehicles pay a higher base toll, with the toll determined by the total number of axles on the roadway in } \\
\text { a vehicle combination } \\
\text { - Commuter bus or a vanpool vehicle may cross toll-free at any time in designated lane(s), in accordance with } \\
\text { Authority operational procedures } \\
\text { - Passage through staffed lanes requires a toll-free commute bus ticket or non-revenue FasTrak } ® \text { toll tag issued by } \\
\text { the Authority } \\
\text { - A } 50 \% \text { discount applies to HOV ( } 3 \text { or more) and registered hybrid vehicles during designated times and through } \\
\text { designated lanes }\end{array}$} \\
\hline $\begin{array}{l}\text { Ongoing Transit } \\
\text { Operating/Capit }\end{array}$ & & \multicolumn{8}{|c|}{$\begin{array}{l}\text { Approximately } 18 \% \text { of the base toll collected from the bridges has been statutorily set aside for transit improvement } \\
\text { purposes. This toll revenue is transferred from BATA into three separate Metropolitan Transportation Commission } \\
\text { (MTC) reserve accounts: (A) AB } 664 \text { Net Toll Revenue Reserves, (B) Five Percent Reserves, and (C) Regional Measure } \\
1 \text { Rail Extension Reserves. }\end{array}$} \\
\hline
\end{tabular}




\begin{tabular}{|c|c|c|c|c|c|c|c|c|}
\hline $\begin{array}{l}\text { No. Facilities/ } \\
\text { Miles }\end{array}$ & $\begin{array}{l}\text { Project } \\
\text { Type }\end{array}$ & $\begin{array}{l}\text { Pricing } \\
\text { Type }\end{array}$ & Toll Rates & $\begin{array}{l}\text { Funding } \\
\text { Recipient }\end{array}$ & Project Type & $\begin{array}{l}\text { Value Pricing } \\
\text { Pilot Program }\end{array}$ & $\begin{array}{l}\text { Pricing } \\
\text { Type }\end{array}$ & Grant \\
\hline $\begin{array}{l}\text { SR 73: } 15 \text { miles } \\
\text { SJHTC: } 12 \text { miles } \\
\text { SR 261: } 6.6 \text { miles } \\
\text { SR 241: } 22.2 \text { miles } \\
\text { SR 133: } 4.1 \text { miles }\end{array}$ & Highway & Peak-period & $\begin{array}{l}\$ 3.95-\$ 5.75 \\
\$ 1.30-\$ 2.25 \\
\$ 2.10-\$ 3.00 \\
\$ 1.60-\$ 2.25\end{array}$ & $\begin{array}{l}\text { Orange } \\
\text { County, CA }\end{array}$ & $\begin{array}{l}\text { Managed } \\
\text { facility/lanes }\end{array}$ & Priced tollway & VPP & $\$ 535,200$ \\
\hline Project & \multicolumn{8}{|c|}{$\begin{array}{l}\text { Implementation of peak pricing and variable tolls on the San Joaquin Hills Transportation Corridor (SJHTC) and SR } \\
73 \text {, since February } 2002\end{array}$} \\
\hline Status & \multicolumn{8}{|c|}{ Study completed and project implemented } \\
\hline Toll Schedule & \multicolumn{8}{|c|}{$\begin{array}{l}\text { - A small peak period premium that was implemented at the mainline plaza in February } 2002 \text { was increased to } \\
\$ 0.50 \text { in July } 2005 \text { and to } \$ 0.75 \text { in July } 2006 \\
\text { - Premium was designed to reduce congestion and spread peak demand to shoulder and off-peak periods, while } \\
\text { maintaining revenues at required levels } \\
\text { - No discount tolls for carpools, commuters, energy efficient vehicles, or transit }\end{array}$} \\
\hline $\begin{array}{l}\text { Ongoing Transit } \\
\text { Operating/Capital }\end{array}$ & \multicolumn{8}{|c|}{$\begin{array}{l}\text { The San Joaquin Hills (SR 73), Foothill (SR 241), and Eastern (SRs 241/261/133) Toll Roads were the first public } \\
\text { highways to be constructed in Orange County since } 1987 \text {. The Toll Roads, owned and maintained by the State of } \\
\text { California, were built with virtually no taxpayer dollars. The Transportation Corridor Agency (TCA) is funded by the } \\
\text { sale of bonds to both private individuals and institutional investors. The bonds can be repaid only by future tolls anc } \\
\text { development fees. Since the bonds are not backed by the government, taxpayers are not responsible for repaying } \\
\text { the debt if future toll revenues fall short. Today, toll and development impact fee revenue go toward retiring the } \\
\text { construction debt, funding additional improvements, and covering costs of operating. }\end{array}$} \\
\hline
\end{tabular}




\begin{tabular}{|c|c|c|c|c|c|c|c|c|}
\hline \multicolumn{9}{|c|}{ SR 91 - Orange County, CA - FY 1999} \\
\hline $\begin{array}{l}\text { No. Facilities/ } \\
\text { Miles }\end{array}$ & $\begin{array}{l}\text { Project } \\
\text { Type }\end{array}$ & Pricing Type & Toll Rates & $\begin{array}{l}\text { Funding } \\
\text { Recipient }\end{array}$ & Project Type & $\begin{array}{l}\text { Value Pricing } \\
\text { Pilot Program }\end{array}$ & $\begin{array}{l}\text { Pricing } \\
\text { Type }\end{array}$ & Grant \\
\hline 10 miles & HOT lane & Variable & $\$ 1.30-\$ 9.75$ & $\begin{array}{l}\text { Orange } \\
\text { County, CA }\end{array}$ & Managed lanes & Priced lanes & ETL & $\$ 314,762$ \\
\hline Project & \multicolumn{8}{|c|}{$\begin{array}{l}\text { Evaluation of value-priced express lanes in median of Riverside Freeway (SR 91) in Orange County, CA, since } \\
\text { December } 27,1995\end{array}$} \\
\hline Status & \multicolumn{8}{|c|}{$\begin{array}{l}\text { Study completed: "Continuation Study to Evaluate the Impacts of the SR } 91 \text { Value Prices Express Lanes," Final } \\
\text { Report, December } 2000\end{array}$} \\
\hline Toll Schedule & \multicolumn{8}{|c|}{$\begin{array}{l}\text { - } \text { Routinely spend less than } \$ 7 \text { in tolls per month per transponder } \\
\text { - } \quad \text { No monthly toll requirements } \\
\text { - } \text { One-time refundable } \$ 75 \text { per transponder enrollment fee } \\
-\quad \$ 75 \text { one-time, } 2-25 \text { one-way trips per month } \\
-\quad \text { Pay a minimum of } \$ 7 \text { in tolls each calendar month for each transponder } \\
-\quad \$ 7 \text { min/mo. - more than } 20 \text { one-way trips per month } \\
-\quad \$ 20 \text { per transponder monthly membership fee } \\
-\quad \text { Receive a } \$ 1 \text { per trip discount for all tolled trips } \\
-\quad \$ 20 / \text { mo. }+\$ 1 \text { discount per trip } \\
-\quad \text { Special access accounts: three or more people in one vehicle; drive a motorcycle; drive a pure zero-emission } \\
\text { vehicle; have a disabled veteran or disabled person license plate issued by the DMV - These do not apply on } \\
\text { weekdays on eastbound lanes between } 4 \text { and } 6 \text { p.m. when a } 50 \% \text { discount is applied/Free or } 50 \% \text { discount }\end{array}$} \\
\hline $\begin{array}{l}\text { Ongoing Transit } \\
\text { Operating/Capital }\end{array}$ & \multirow{2}{*}{\multicolumn{8}{|c|}{$\begin{array}{l}\text { In 2006, Orange County Transportation Authority (OCTA) introduced comfortable, work-ready OC Express buses on } \\
\text { SR } 91 \text { express lanes and freeway HOV lanes. } \\
\text { OCTA Connections is OCTA's e-newsletter: } 91 \text { Express Lanes, Metrolink rail service, freeway improvement projects, } \\
\text { local street improvements. There are two full-service walk-in customer service centers: to update } 91 \text { Express Lanes } \\
\text { account information, replace or add transponders, make payments, or open a new account. OCTA bus transit } \\
\text { information and passes are available at the Orange Store location. }\end{array}$}} \\
\hline Outreach & & & & & & & & \\
\hline
\end{tabular}




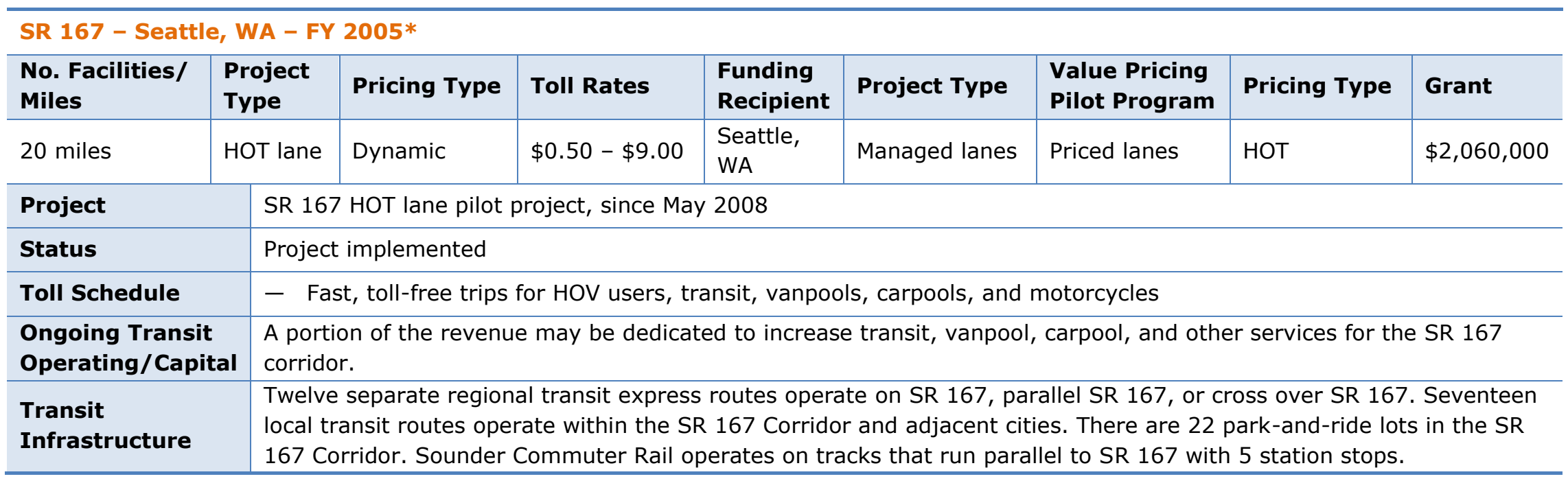

*Discussed in detail in the report. 


\begin{tabular}{|c|c|c|c|c|c|c|c|c|c|}
\hline $\begin{array}{l}\text { No. Facilities/ } \\
\text { Miles }\end{array}$ & & & $\begin{array}{l}\text { Pricing } \\
\text { Type }\end{array}$ & Toll Rates & $\begin{array}{l}\text { Funding } \\
\text { Recipient }\end{array}$ & $\begin{array}{l}\text { Project } \\
\text { Type }\end{array}$ & $\begin{array}{l}\text { Value Pricing } \\
\text { Pilot Program }\end{array}$ & $\begin{array}{l}\text { Pricing } \\
\text { Type }\end{array}$ & Grant \\
\hline Bridge & Bri & dge & Variable & $\$ 0.00-\$ 5.00$ & $\begin{array}{l}\text { Washington } \\
\text { State Dept. of } \\
\text { Transportation } \\
\text { /King County/ } \\
\text { Puget Sound, WA }\end{array}$ & UPA & $\begin{array}{l}\text { High-performance } \\
\text { highway }\end{array}$ & VPP & $\$ 10,000,000$ \\
\hline Project & & \multicolumn{8}{|c|}{$\begin{array}{l}\text { Seattle/Lake Washington Corridor Tolling and Transit UPA; introduction of tolling to SR } 520 \text {; and toll rates based on } \\
\text { demand to avoid congestion and loss of capacity }\end{array}$} \\
\hline Status & & \multicolumn{8}{|c|}{ Study was completed and project was implemented in 2011} \\
\hline Toll Schedule & & \multicolumn{8}{|c|}{$\begin{array}{l}\text { - Registered vanpools and transit are exempt from tolls on the SR } 520 \text { bridge, along with emergency response } \\
\text { vehicles such as police, fire, and ambulances on bona-fide emergencies } \\
\text { - Washington State Patrol vehicles assigned to the bridge, tow trucks authorized by the Washington State Patrol to } \\
\text { clear a blocking incident, and bridge maintenance vehicles } \\
\text { - Carpools and motorcycles are not exempt } \\
\text { - Variable toll rates } 7 \text { days a week from } 5 \text { a.m. to } 11 \text { p.m. } \\
\text { - Good to Go discount pass (SR 520, Tacoma Narrows Bridge, and SR } 167 \text { ) or Pay by Mail } \\
\text { - Weekday: } \$ 1.64-\$ 3.59 \text { Pass vs. } \$ 3.18-\$ 5.13 \text { Mail / Weekend: } \$ 1.13-\$ 2.26 \text { Pass vs. } \$ 2.67-\$ 3.79 \text { Mail }\end{array}$} \\
\hline $\begin{array}{l}\text { Ongoing Transi } \\
\text { Operating/Capi }\end{array}$ & & \multicolumn{8}{|c|}{$\begin{array}{l}\text { Added } 130 \text { bus trips to routes on SR } 520 \text { for a total of } 700 \text { every weekday, plus a new route on SR } 522 \text {. } \\
\text { Improvements to bus stops and park-and-rides. Revenue from tolling the bridge will be used only as authorized by } \\
\text { the legislature for bond payments, operations, and maintenance within the SR } 520 \text { corridor. }\end{array}$} \\
\hline Outreach & & \multicolumn{8}{|c|}{$\begin{array}{l}\text { Coordinate with local jurisdictions to monitor key routes on highway and local streets. Closely monitor all of the Lake } \\
\text { Washington corridors to determine how tolling affects traffic. Monitoring work will compare traffic conditions after } \\
\text { tolling to pre-toll conditions. Also track travel times, coordinate signals, and collect traffic count data on highways and } \\
\text { local roads. Regularly report on traffic conditions to the legislature, local governments, and the transportation } \\
\text { commission. }\end{array}$} \\
\hline $\begin{array}{l}\text { Transit } \\
\text { Infrastructure }\end{array}$ & & \multicolumn{8}{|c|}{ Will accommodate light rail in the future. } \\
\hline
\end{tabular}

*Discussed in detail in the report. 


\begin{tabular}{|c|c|c|c|c|c|c|c|c|}
\hline \multicolumn{9}{|c|}{ Tappan Zee Bridge - New York, NY } \\
\hline \multirow[t]{2}{*}{$\begin{array}{l}\text { No. Facilities/ } \\
\text { Miles }\end{array}$} & \begin{tabular}{|l|} 
Project \\
Type
\end{tabular} & Pricing Type & Toll Rates & $\begin{array}{l}\text { Funding } \\
\text { Recipient }\end{array}$ & Project Type & $\begin{array}{l}\text { Value Pricing } \\
\text { Pilot Program }\end{array}$ & Pricing Type & Grant \\
\hline & & & $\$ 1.55-\$ 13.95$ & & & & & \\
\hline Toll Schedule & $\begin{array}{ll}- & \text { Or } \\
& \text { rat } \\
- & \mathrm{Cu} \\
- & \mathrm{To} \\
& \mathrm{Cu} \\
- & \mathrm{E}- \\
- & \mathrm{Ca} \\
& (2 \\
- & \$ 0\end{array}$ & $\begin{array}{l}\text { veekends E-ZPa } \\
\text { fomers who do } \\
\text { for Class } 2 \mathrm{~L} \text { veh } \\
\text { omers that have } \\
\text { ass discount }= \\
\text { ool Commuter } \\
\text { trips at } \$ 0.50 \mathrm{p} \\
0 \text { toll applies on }\end{array}$ & $\begin{array}{l}\text { s customers with } \\
\text { th use E-ZPass tac } \\
\text { cles at the Tappan } \\
\text { an individual E-ZF } \\
\% \\
\text { an: } 3 \text { or more occ } \\
\text { trip) vs. the full } \\
\text { y at staffed lanes; }\end{array}$ & $\begin{array}{l}\text { ll class } 3 \mathrm{~L}-7 \mathrm{H} \\
\text { pay the } 7: 00 \\
\text { Zee Bridge is } \\
\text { ss account } w \\
\text { ipants in the } \\
\text { of } \$ 5.00 \mathrm{p} \\
\$ 3.00 \text { per trip }\end{array}$ & $\begin{array}{l}\text { vehicles are ch } \\
\text { a.m. - 8:59 a.r } \\
\$ 5.00 \text { (cash) or } \\
\text { th a bridge com } \\
\text { ehicle and mont } \\
r \text { trip } \\
\text { is charged in ur }\end{array}$ & $\begin{array}{l}\text { rged the } 12: 00 \text { a. } \\
\text { rate at all times } \\
4.75 \text { ( } E-Z \text { Pass) at } \\
\text { uter or carpool } p \\
\text { ly minimum brids } \\
\text { taffed lanes }\end{array}$ & $\begin{array}{l}\text { n. (midnight) - } \\
\text { all times, excep } \\
\text { an } \\
\text { e usage charge }\end{array}$ & $\begin{array}{l}6: 14 \text { a.m. } \\
t \text { for those } \\
\text { of } \$ 10.00\end{array}$ \\
\hline
\end{tabular}




\title{
Appendix B \\ DOT's Managed Facility Value Pricing Pilot Program Grants, Fiscal Years 2000 - 2011
}

\author{
Sources: GAO Report 12-119, Federal Highway Administration \\ Express Lane Demonstration Project (ELDP)
}

\begin{tabular}{|c|c|c|c|c|}
\hline \multicolumn{5}{|c|}{ Miami-Dade County, FL - FY 2000} \\
\hline \multicolumn{2}{|c|}{ Project Type } & Value Pricing Pilot Program & Pricing Type & Grant \\
\hline \multicolumn{2}{|c|}{ Managed facility } & Priced tollway & VPP & $\$ 696,320$ \\
\hline Project & \multicolumn{4}{|c|}{$\begin{array}{l}\text { Study feasibility of implementing value pricing on a } 21 \text {-mile section of the Homestead } \\
\text { Extension of Florida's Turnpike (HEFT) }\end{array}$} \\
\hline Status & \multicolumn{4}{|c|}{ Study completed. Elimination of cash payments for tolls was the largest obstacle. } \\
\hline \multicolumn{5}{|c|}{ Philadelphia, PA - FY 2001} \\
\hline \multicolumn{2}{|c|}{ Project Type } & Value Pricing Pilot Program & Pricing Type & Grant \\
\hline \multicolumn{2}{|c|}{ Managed facility } & Priced tollway & VPP & $\$ 776,000$ \\
\hline Project & \multicolumn{4}{|c|}{$\begin{array}{l}\text { Study potential for value pricing strategies to alleviate congestion, facilitate movement o } \\
\text { commercial vehicles to industrial and commercial destinations, and to improve the } \\
\text { movement of daily commuter vehicles to and from the workplace. Concurrent with the } \\
\text { value pricing study, the Pennsylvania Turnpike Commission (PTC) implemented ETC (E- } \\
\text { ZPass) for travel between ticket interchanges on its mainline system. }\end{array}$} \\
\hline Status & \multicolumn{4}{|c|}{ Study completed. } \\
\hline
\end{tabular}

Philadelphia, PA - FY 2002
\begin{tabular}{|l|l|l|l|}
\hline Project Type & Value Pricing Pilot Program & Pricing Type & Grant \\
\hline Managed facility & Priced tollway & VPP & $\$ 800,000$ \\
\hline Project & Explore variable tolls on PA turnpike. & & \\
\hline Status & Implementation. & & \\
\hline
\end{tabular}

\section{Chicago, IL - FY 2003}

\begin{tabular}{|l|l|l|l|}
\hline Project Type & Value Pricing Pilot Program & Pricing Type & Grant \\
\hline Managed facility & Priced tollway & VPP & $\$ 360,000$
\end{tabular}

Project Study variable tolls on Northwest Tollway. Phase 1 was designed as a basic feasibility study and evaluation of possible pricing options.

Status Study completed. Illinois Tollway approved a comprehensive Congestion-Relief Plan in September 2004 that included value pricing concepts. 


\begin{tabular}{l|l|l|l}
\hline \multicolumn{2}{l}{ Atlanta, GA - FY 2005} & & \\
\hline Project Type & Value Pricing Pilot Program & Pricing Type & Grant \\
\hline Managed facility & Priced lanes & TOT/HOT & $\$ 242,388$ \\
\hline Project & Study feasibility of implementing HOT/Truck-Only Toll (TOT) lanes on I-75 South. \\
\hline Status & $\begin{array}{l}\text { Feasibility study completed: "Study of Potential Managed Lanes on I-75 South Corridor, } \\
\text { November 2008, FINAL," but not pursuing implementation. }\end{array}$ \\
\hline
\end{tabular}

\begin{tabular}{|c|c|c|c|c|}
\hline \multicolumn{5}{|c|}{ Savannah, GA - FY 2005} \\
\hline \multicolumn{2}{|c|}{ Project Type } & Value Pricing Pilot Program & Pricing Type & Grant \\
\hline \multicolumn{2}{|c|}{ Managed facility } & Priced lanes & TOT & $\$ 472,000$ \\
\hline Project & \multicolumn{4}{|c|}{$\begin{array}{l}\text { Examined a truck-only toll facility extending from Georgia State Route } 21 \text { near I-95 tc } \\
\text { I-16 at the intersection of I-516 (Savannah). }\end{array}$} \\
\hline Status & \multicolumn{4}{|c|}{ Study completed, but not pursuing implementation. } \\
\hline
\end{tabular}

NE Illinois, IL - FY 2006

\begin{tabular}{l|l|l|l}
\hline Project Type & Value Pricing Pilot Program & Pricing Type & Grant \\
\hline Managed facility & System-wide pricing & $\begin{array}{l}\text { VPP comprehensive } \\
\text { pricing }\end{array}$ & $\$ 750,000$ \\
\hline Project & $\begin{array}{l}\text { Study comprehensive pricing in NE Illinois: feasibility of variable tolls on tolled routes; } \\
\text { feasibility of using congestion pricing to manage peak period traffic congestion in the } \\
\text { Chicago region; increase use of alternate travel modes; and enhance system capacity. }\end{array}$ \\
\hline Status & Study completed and considering pricing in 2 corridors. \\
\hline
\end{tabular}

\begin{tabular}{l|l|l|l}
\hline Port Authority of New York and New Jersey, NJ - FY 2007 & \\
\hline Project Type & Value Pricing Pilot Program & Pricing Type & Grant \\
\hline Managed facility & VPP & $\$ 988,000$ \\
\hline Project $\quad$ Upgrade electronic toll collection technology. & \\
\hline Status & Study was withdrawn. & \\
\hline
\end{tabular}

\section{Twin Cities Area, MN - FY 2009}

\begin{tabular}{l|l|l|l|} 
Project Type & Value Pricing Pilot Program & Pricing Type & Grant \\
\hline Managed facility & Priced lanes & ETL & $\$ 540,000$ \\
\hline Project & Study feasibility of pricing innovative lane additions on Trunk Highway 77. \\
\hline Status & $\begin{array}{l}\text { Analysis completed and final recommendations anticipated as early as 2011. Study was } \\
\text { withdrawn. }\end{array}$
\end{tabular}




\begin{tabular}{|c|c|c|c|c|}
\hline \multicolumn{5}{|c|}{ Connecticut Department of Transportation, CT - FY 2011} \\
\hline \multicolumn{2}{|c|}{ Project Type } & Value Pricing Pilot Program & Pricing Type & Grant \\
\hline \multicolumn{2}{|c|}{ Managed facility } & Priced lanes & ETL & $\$ 1,120,000$ \\
\hline Project & \multicolumn{4}{|c|}{$\begin{array}{l}\text { Study application of full facility pricing to the I-95 Corridor (includes two expressways } \\
\text { and a major commuter rail line) from New York to New Haven, CT, and identify how toll } \\
\text { revenues would be applied to provide strong support for transit. }\end{array}$} \\
\hline Status & \multicolumn{4}{|c|}{ Approved for funding. FHWA awarded and allocated funds on February 6, 2012.} \\
\hline \multicolumn{5}{|c|}{ Florida Turnpike Enterprise, FL - FY 2011} \\
\hline \multicolumn{2}{|c|}{ Project Type } & Value Pricing Pilot Program & Pricing Type & Grant \\
\hline \multicolumn{2}{|c|}{ Managed facility } & System-wide pricing & $\begin{array}{l}\text { VPP/Integrated } \\
\text { congestion pricing }\end{array}$ & $\$ 600,000$ \\
\hline Project & \multicolumn{4}{|c|}{$\begin{array}{l}\text { Evaluate two-tiered pricing on an existing toll facility and develop performance measures } \\
\text { to track the changes in congestion, air quality, safety, livability, and other factors that } \\
\text { would result. }\end{array}$} \\
\hline Status & \multicolumn{4}{|c|}{ Approved for funding with a completion date of 2013 . } \\
\hline
\end{tabular}

\begin{tabular}{l|l|l|l}
\hline \multicolumn{1}{|l}{ Illinois State Highway Tollway Authority - FY 2011} & & \\
\hline Project Type & Value Pricing Pilot Program & Pricing Type & Grant \\
\hline Managed facility & Priced tollway & $\begin{array}{l}\text { Integrating and } \\
\text { financing transit with } \\
\text { managed lanes }\end{array}$ & $\$ 528,840$ \\
\hline
\end{tabular}

Project

Status
Study will look at the application of pricing on an existing toll road, and will evaluate steps to mitigate equity concerns for potential low-income users. The project will also evaluate how transit could be integrated and financed through priced managed lanes. Approved for funding with feasibility funds awarded 2011. Anticipated completion date is 2013. 


\title{
Appendix C \\ DOT's Managed Lane Value Pricing Pilot Program Grants, Fiscal Years 2000 - 2010
}

\author{
Sources: GAO Report 12-119, Federal Highway Administration \\ Express Lane Demonstration Project (ELDP)
}

\begin{tabular}{|c|c|c|c|c|}
\hline \multicolumn{5}{|c|}{ Santa Cruz, CA - FY 2000} \\
\hline \multicolumn{2}{|c|}{ Project Type } & Value Pricing Pilot Program & Pricing Type & Grant \\
\hline \multicolumn{2}{|c|}{ Managed lanes } & Priced lanes & HOT & $\$ 264,000$ \\
\hline Project & \multicolumn{4}{|c|}{5 HOT lanes as alternatives for Route 1 were studied. } \\
\hline Status & \multicolumn{4}{|c|}{$\begin{array}{l}\text { Results of the study indicated that HOT lanes in the study corridor would be subject to a } \\
\text { number of design and operation constraints due to the short study corridor, multiple } \\
\text { interchanges on the adjacent main lines, and anticipated high levels of HOV traffic. A } \\
\text { carpool lane was selected as an alternative. }\end{array}$} \\
\hline \multicolumn{5}{|c|}{ C-470 - Denver, CO - FY 2001} \\
\hline \multicolumn{2}{|c|}{ Project Type } & Value Pricing Pilot Program & Pricing Type & Grant \\
\hline \multicolumn{2}{|c|}{ Managed lanes } & Priced lanes & ETL & $\$ 500,000$ \\
\hline Project & \multicolumn{4}{|c|}{$\begin{array}{l}\text { Study the design, operational and financial feasibility, and expected public acceptance of } \\
\text { express lanes on the } 26 \text {-mile C- } 470 \text { beltway in the southwest part of the Denver metro } \\
\text { area. }\end{array}$} \\
\hline Status & \multicolumn{4}{|c|}{$\begin{array}{l}\text { Study completed: "C- } 470 \text { Corridor Express Lanes Feasibility Study Final Report, June } \\
\text { 2005." Project is on hold until further notification is given by the Colorado Department of } \\
\text { Transportation. }\end{array}$} \\
\hline
\end{tabular}

\section{Broward County, FL - FY 2002}

\begin{tabular}{|c|c|c|c|c|}
\hline \multicolumn{2}{|c|}{ Project Type } & Value Pricing Pilot Program & Pricing Type & Grant \\
\hline \multicolumn{2}{|c|}{ Managed lanes } & Priced tollway & VPP/ORT & $\$ 320,000$ \\
\hline Project & \multicolumn{4}{|c|}{$\begin{array}{l}\text { Pilot project to combine Open Road Tolling (ORT) and Value Pricing (VPP) on Sawgrass } \\
\text { Expressway. }\end{array}$} \\
\hline Status & \multicolumn{4}{|c|}{$\begin{array}{l}\text { Study was completed. Elimination of cash payments for tolls was the largest obstacle } \\
\text { faced. }\end{array}$} \\
\hline
\end{tabular}




\begin{tabular}{|c|c|c|c|c|}
\hline \multicolumn{5}{|c|}{ I-30 - Dallas-Fort Worth, TX - FY 2002} \\
\hline \multicolumn{2}{|c|}{ Project Type } & Value Pricing Pilot Program & Pricing Type & Grant \\
\hline \multicolumn{2}{|c|}{ Managed lanes } & Priced lanes & ETL & $\$ 152,000$ \\
\hline Project & \multicolumn{4}{|c|}{$\begin{array}{l}\text { Project opened in August } 2007 \text { as an interim "Managed HOV Lane." The project is } \\
\text { operating in HOV-only mode. It will transition to "Express Lanes" with pricing in later } \\
\text { phases as the tolling infrastructure is constructed. }\end{array}$} \\
\hline Status & \multicolumn{4}{|c|}{ Study completed: "I-30 Value Pricing Pilot Program for Dallas District, August 2010." } \\
\hline \multicolumn{5}{|c|}{ Highway 217 - Portland, OR - FY 2002} \\
\hline \multicolumn{2}{|c|}{ Project Type } & Value Pricing Pilot Program & Pricing Type & Grant \\
\hline \multicolumn{2}{|c|}{ Managed lanes } & Priced lanes & ETL & $\$ 400,000$ \\
\hline Project & \multicolumn{4}{|c|}{$\begin{array}{l}\text { Develop and evaluate several rush-hour toll and ramp meter bypass alternatives in the } \\
\text { Highway } 217 \text { corridor, including consideration of Fast and Intertwined Regular (FAIR) } \\
\text { lanes among other value pricing approaches at ramp meters. }\end{array}$} \\
\hline Status & \multicolumn{4}{|c|}{$\begin{array}{l}\text { Study completed: "Highway } 217 \text { Corridor Study Phase II Overview Report - Study } \\
\text { Findings and Recommendation, October 7, 2005." Further study is on hold, pending } \\
\text { funding for an environmental impact study. }\end{array}$} \\
\hline
\end{tabular}

I-40 - Raleigh/Piedmont, NC - FY 2002

\begin{tabular}{l|l|l|l}
\hline Project Type & Value Pricing Pilot Program & Pricing Type & Grant \\
\hline Managed lanes & Priced lanes & HOT & $\$ 402,400$ \\
\hline
\end{tabular}

\begin{tabular}{l|l}
\hline Project & $\begin{array}{l}\text { Study HOT lanes and other potential value pricing options on I-40 in North Carolina's } \\
\text { Piedmont (Greensboro, High Point, and Winston-Salem) and Research Triangle (Raleigh } \\
\text { and Durham) areas. }\end{array}$ \\
\hline Status & Study was completed. The environmental assessment has not been completed. \\
\hline
\end{tabular}

\section{I-35 - San Antonio, TX - FY 2003}

\begin{tabular}{|c|c|c|c|c|}
\hline \multicolumn{2}{|c|}{ Project Type } & Value Pricing Pilot Program & Pricing Type & Grant \\
\hline \multicolumn{2}{|c|}{ Managed lanes } & Priced lanes & ETL & $\$ 160,000$ \\
\hline Project & \multicolumn{4}{|c|}{$\begin{array}{l}\text { Evaluate managed lane options for a } 15 \text {-mile section of the Northeast Corridor (I-35) } \\
\text { This project is San Antonio's first VPPP grant. }\end{array}$} \\
\hline Status & \multicolumn{4}{|c|}{ Study was completed and referred to the Regional Mobility Authority. } \\
\hline
\end{tabular}




\begin{tabular}{|c|c|c|c|c|}
\hline \multicolumn{5}{|c|}{ I-75 - Atlanta, GA - FY 2004} \\
\hline \multicolumn{2}{|c|}{ Project Type } & Value Pricing Pilot Program & Pricing Type & Grant \\
\hline \multicolumn{2}{|c|}{ Managed lanes } & Priced lanes & ETL & $\$ 400,000$ \\
\hline Project & \multicolumn{4}{|c|}{$\begin{array}{l}\text { Examined I-75 travel corridor in Atlanta to determine if value pricing in combination with } \\
\text { Bus Rapid Transit (BRT) could reduce the existing high levels of congestion. }\end{array}$} \\
\hline Status & \multicolumn{4}{|c|}{$\begin{array}{l}\text { Study completed: "Interstate } 75 \text { Stated Preference Survey Final Report, November } \\
\text { 2005," and pursuing implementation. Based on the combined assessment of traffic and } \\
\text { toll revenue, A-3 Express Toll Lanes (Cars Only) was selected as the preferred alternative } \\
\text { for the corridor due to revenue potential versus estimated costs. It was considered to be } \\
\text { the alternative that provides the most efficient use of public funds. }\end{array}$} \\
\hline
\end{tabular}

\begin{tabular}{l|l|l|l}
\hline GA-400 - Atlanta, GA - FY 2005 \\
\begin{tabular}{l|l|l|l} 
Project Type & Value Pricing Pilot Program & Pricing Type & Grant \\
\hline Managed lanes & Priced tollway & VPP & $\$ 444,000$ \\
\hline Project & $\begin{array}{l}\text { Study the institutional challenges and feasibility of moving from a fixed-price toll to a } \\
\text { variably priced toll system using GA-400 as a case study. }\end{array}$ & \\
\hline Status & Study was completed and project was implemented. & \\
\hline
\end{tabular}
\end{tabular}

\begin{tabular}{|c|c|c|c|c|}
\hline \multicolumn{5}{|c|}{ MoPac Expressway - Austin, TX - FY 2005} \\
\hline \multicolumn{2}{|c|}{ Project Type } & Value Pricing Pilot Program & Pricing Type & Grant \\
\hline \multicolumn{2}{|c|}{ Managed lanes } & Priced lanes & HOT & $\$ 172,000$ \\
\hline Project & \multicolumn{4}{|c|}{$\begin{array}{l}\text { Study Loop } 1 \text { (MoPac Expressway) HOT Lane Enforcement and Operations in Austin. HOT } \\
\text { lane will be actively managed according to an operational plan that triggers changes in } \\
\text { price in order to maintain free flow conditions for express bus/BRT. }\end{array}$} \\
\hline Status & \multicolumn{4}{|c|}{$\begin{array}{l}\text { Completed } 4 \text { technical memoranda in December 2009. The Texas Department of } \\
\text { Transportation, in partnership with the Central Texas Regional Mobility Authority, the } \\
\text { City of Austin, and Capital Metro, has studied the problem and completed a Draft } \\
\text { Environmental Assessment, which recommends that one express lane be constructed in } \\
\text { each direction. The express lane alternative includes the construction of ramps, bicycle } \\
\text { and pedestrian improvements, and noise barriers. FHWA is expected to issue a final } \\
\text { decision regarding the proposal by fall } 2012 \text {. }\end{array}$} \\
\hline
\end{tabular}

\begin{tabular}{l|l|l|l}
\hline \multicolumn{2}{l}{ Austin, TX - FY 2005} & & \\
\hline Project Type & Value Pricing Pilot Program & Pricing Type & Grant \\
\hline Managed lanes & Priced tollway & VPP & $\$ 148,000$ \\
\hline Project & $\begin{array}{l}\text { Examine the use of value pricing to encourage truck traffic to divert from I-35 to a newly } \\
\text { constructed, parallel toll facility, and methods to encourage route and time-of-travel } \\
\text { shifting. }\end{array}$ \\
\hline Status & Study was withdrawn. \\
\hline
\end{tabular}




\begin{tabular}{|c|c|c|c|c|}
\hline \multicolumn{5}{|c|}{ Baltimore, MD - FY 2005} \\
\hline \multicolumn{2}{|c|}{ Project Type } & Value Pricing Pilot Program & Pricing Type & Grant \\
\hline \multicolumn{2}{|c|}{ Managed lanes } & Priced lanes & ETL & $\$ 0$ \\
\hline Project & \multicolumn{4}{|c|}{$\begin{array}{l}\text { In July 2005, FHWA/MDOT/MdTA signed a VPP toll agreement authorizing collection of } \\
\text { tolls on new ETLs on: I-95/JFK Expressway in Baltimore (Section 100) and Section 200, a } \\
\text { 10-mile stretch north of Section } 100 .\end{array}$} \\
\hline Status & \multicolumn{4}{|c|}{ Section 100 is to be completed in 2014. No funds are programmed for Section 200.} \\
\hline
\end{tabular}

I-10 - San Antonio, TX - FY 2005

\begin{tabular}{|c|c|c|c|c|}
\hline \multicolumn{2}{|c|}{ Project Type } & Value Pricing Pilot Program & Pricing Type & Grant \\
\hline \multicolumn{2}{|c|}{ Managed lanes } & Priced lanes & ETL & $\$ 129,600$ \\
\hline Project & \multicolumn{4}{|c|}{$\begin{array}{l}\text { Examine use of value pricing on a 19-mile segment on I-10. Considered use of tolling for } \\
\text { demand management and public acceptance. }\end{array}$} \\
\hline Status & \multicolumn{4}{|c|}{$\begin{array}{l}\text { Study completed: "San Antonio IH 10E and IH 10W Corridors: Value Priced Express } \\
\text { Lanes Final Report, September 2009," but not pursuing implementation. }\end{array}$} \\
\hline
\end{tabular}

Waco, TX - FY 2005

\begin{tabular}{l|l|l|l}
\hline Project Type & Value Pricing Pilot Program & Pricing Type & Grant \\
\hline Managed lanes & & & $\$ 440,000$ \\
\hline
\end{tabular}

Project $\quad$ Study value priced express lanes on I-35.

Status Study was complete. ELDP toll agreement and pursuing funding.

\section{Washington, DC - FY 2005}

\begin{tabular}{l|l|l|l|}
\hline Project Type & Value Pricing Pilot Program & Pricing Type & Grant \\
\hline Managed lanes & $\$ 240,000$ \\
\hline Project & Regional network of value-priced lanes. & \\
\hline Status & Section 100 to be completed in 2014; no funds are programmed for Section 200. \\
\hline
\end{tabular}

\begin{tabular}{|c|c|c|c|c|}
\hline \multicolumn{5}{|c|}{ Riverside County, CA - FY 2006} \\
\hline \multicolumn{2}{|c|}{ Project Type } & Value Pricing Pilot Program & Pricing Type & Grant \\
\hline \multicolumn{2}{|c|}{ Managed lanes } & Priced lanes & TOT & $\$ 118,311$ \\
\hline Project & \multicolumn{4}{|c|}{$\begin{array}{l}\text { Analyze environmental effects of PierPass, which provides off-peak truck discounts from } \\
\text { the normal charges for accessing the Ports of Los Angeles and Long Beach. }\end{array}$} \\
\hline Status & \multicolumn{4}{|c|}{ Study was completed. } \\
\hline
\end{tabular}




\begin{tabular}{|c|c|c|c|c|}
\hline \multicolumn{5}{|c|}{ Twin Cities, MN - FY 2007} \\
\hline \multicolumn{2}{|c|}{ Project Type } & Value Pricing Pilot Program & Pricing Type & Grant \\
\hline \multicolumn{2}{|c|}{ Managed lanes } & System-wide pricing & FAST miles & $\$ 60,000$ \\
\hline Project & \multicolumn{4}{|c|}{$\begin{array}{l}\text { Explore political feasibility of an innovative pricing concept called "FAST Miles," where } \\
\text { each motorist is provided a number of dollar credits per month, analogous to the "free } \\
\text { minutes" given by cell phone providers. Motorist can apply those credits to use priced } \\
\text { lanes, but once credits are exhausted, motorist is charged the going rate to use the } \\
\text { priced lanes. FAST Miles encourages carpooling for motorists who pool credits. }\end{array}$} \\
\hline Status & \multicolumn{4}{|c|}{ Study was completed and project was implemented. } \\
\hline \multicolumn{5}{|c|}{ I-495 Capital Beltway - Fairfax County, VA - FY 2008} \\
\hline \multicolumn{2}{|c|}{ Project Type } & Value Pricing Pilot Program & Pricing Type & Grant \\
\hline \multicolumn{5}{|c|}{ Managed lanes } \\
\hline Project & \multicolumn{4}{|c|}{$\begin{array}{l}\text { Federal, state, and local leaders broke ground on July } 22,2008 \text {, on a } \$ 1.4 \text { billion public- } \\
\text { private transportation project on the I- } 495 \text { Capital Beltway in Fairfax County. The project } \\
\text { will establish the Beltway's first-ever HOV network for carpools and vanpools, and } \\
\text { provide opportunities for new bus services. Vehicles carrying } 3 \text { or more people and } \\
\text { motorcycles will travel for free, while other motorists can opt to pay a toll to use the HOT } \\
\text { lanes or continue to ride in the regular lanes for free. Construction will last } 5 \text { years. }\end{array}$} \\
\hline Status & \multicolumn{4}{|c|}{$\begin{array}{l}\text { Project was approved for funding. FHWA awarded and allocated funds on February } 6 \text {, } \\
2012 .\end{array}$} \\
\hline \multicolumn{5}{|c|}{ SR 237 - Caltrans/Santa Clara Valley Transportation (VTA), CA - FY 2009} \\
\hline \multicolumn{2}{|c|}{ Project Type } & Value Pricing Pilot Program & Pricing Type & Grant \\
\hline \multicolumn{2}{|c|}{ Managed lanes } & System-wide pricing & Express connectors & $\$ 3,200,000$ \\
\hline Project & \multicolumn{4}{|c|}{$\begin{array}{l}\text { Implement roadway pricing on SR } 237 \text { Express Connectors based on the following } \\
\text { system-wide pricing: carpools with } 2 \text { or more occupants, motorcycles, transit buses, and } \\
\text { eligible hybrids will use the Express Connectors free of charge; solo drivers must pay a } \\
\text { toll during commute hours; and tolls will vary based on level of congestion, and will be } \\
\text { adjusted to maintain a free-flowing ride. }\end{array}$} \\
\hline Status & \multicolumn{4}{|c|}{ Tolling operations were scheduled to begin on March 15, 2012.} \\
\hline
\end{tabular}




\begin{tabular}{|c|c|c|c|c|}
\hline \multicolumn{5}{|c|}{ I-595 - Florida Department of Transportation, FL - FY 2009} \\
\hline \multicolumn{2}{|c|}{ Project Type } & Value Pricing Pilot Program & Pricing Type & Grant \\
\hline \multicolumn{2}{|c|}{ Managed lanes } & Express lanes & ELDP & $\$ 940,000,000$ \\
\hline Project & \multicolumn{4}{|c|}{$\begin{array}{l}\text { ELDP application was approved on July } 1,2009 \text {, and ELDP toll agreement was signed on } \\
\text { September } 30,2009 \text {. ELDP federal funds include a } \$ 603 \text { million TIFIA direct loan, plus } \\
\$ 904 \text { million in federal aid (to be paid out over a } 30 \text {-year concession). }\end{array}$} \\
\hline Status & \multicolumn{4}{|c|}{$\begin{array}{l}\text { I-595 project will include the construction of approximately } 10.5 \text { miles of } 3 \text { new, tolled } \\
\text { express lanes as part of the widening and reconstruction of portions of I-595, in the Ft. } \\
\text { Lauderdale area. Express bus service will operate during peak hours Monday through } \\
\text { Friday, and is anticipated to start in } 2011 \text {, providing premium transit service with wi-fi } \\
\text { and high-back seating. }\end{array}$} \\
\hline
\end{tabular}

\begin{tabular}{|c|c|c|c|c|}
\hline \multicolumn{5}{|c|}{ North Tarrant Express - Texas Department of Transportation, TX - FY 2009} \\
\hline \multicolumn{2}{|c|}{ Project Type } & Value Pricing Pilot Program & Pricing Type & Grant \\
\hline \multicolumn{2}{|c|}{ Managed lanes } & Express lanes & ELDP & $\$ 454,000,000$ \\
\hline Project & \multicolumn{4}{|c|}{$\begin{array}{l}\text { ELDP application was approved on July } 16,2008 \text {, and ELDP toll agreement was signed on } \\
\text { March } 12,2009 . \text { ELDP federal funds include a } \$ 650 \text { million TIFIA direct loan, plus } \\
\text { approximately } \$ 454 \text { million from other federal sources. }\end{array}$} \\
\hline Status & \multicolumn{4}{|c|}{$\begin{array}{l}\text { The North Tarrant Express project would consist of the construction of approximately } 36 \\
\text { miles of new managed (tolled) lanes as part of the reconstruction of portions of I-820, I- } \\
35 \text { W, and State Highway } 183 \text { in the area of Fort Worth. }\end{array}$} \\
\hline
\end{tabular}

\begin{tabular}{|c|c|c|c|c|}
\hline \multicolumn{5}{|c|}{ I-35E - Texas Department of Transportation, TX - FY 2009} \\
\hline \multicolumn{2}{|c|}{ Project Type } & Value Pricing Pilot Program & Pricing Type & Grant \\
\hline \multicolumn{2}{|c|}{ Managed lanes } & Express lanes & ELDP & $\$ 91,430,000$ \\
\hline Project & \multicolumn{4}{|c|}{$\begin{array}{l}\text { The ELDP application was approved on July } 1,2009 \text {, and ELDP toll agreement was signed } \\
\text { on September } 30,2009 . \text { ELDP federal funds identified from various federal sources total } \\
\$ 91.43 \text { million. }\end{array}$} \\
\hline Status & \multicolumn{4}{|c|}{$\begin{array}{l}\text { The I-35E project would consist of the construction of } 28 \text { miles of new managed (tolled) } \\
\text { lanes and access ramps in the Dallas area. }\end{array}$} \\
\hline
\end{tabular}

\begin{tabular}{|c|c|c|c|c|}
\hline \multicolumn{5}{|c|}{ I-635 - Texas Department of Transportation, TX - FY 2009} \\
\hline \multicolumn{2}{|c|}{ Project Type } & Value Pricing Pilot Program & Pricing Type & Grant \\
\hline \multicolumn{2}{|c|}{ Managed lanes } & Express lanes & ELDP & $\$ 261,000,000$ \\
\hline Project & \multicolumn{4}{|c|}{$\begin{array}{l}\text { The ELDP application was approved on March } 19,2008 \text {, and ELDP toll agreement was } \\
\text { signed on March } 12,2009 \text {. ELDP federal funds include an } \$ 850 \text { million TIFIA direct loan, } \\
\text { plus approximately } \$ 261 \text { million in federal grant funds. }\end{array}$} \\
\hline Status & \multicolumn{4}{|c|}{$\begin{array}{l}\text { The I- } 635 \text { project would consist of the construction of } 28 \text { miles of new managed (tolled) } \\
\text { lanes as part of the reconstruction of portions of I- } 635 \text { and I-35E in the Dallas area. }\end{array}$} \\
\hline
\end{tabular}




\begin{tabular}{|c|c|c|c|c|}
\hline \multicolumn{5}{|c|}{ Twin Cities Area, MN - FY 2009} \\
\hline \multicolumn{2}{|c|}{ Project Type } & Value Pricing Pilot Program & Pricing Type & Grant \\
\hline \multicolumn{2}{|c|}{ Managed lanes } & & & $\$ 400,000$ \\
\hline Project & \multicolumn{4}{|c|}{ Pre-implementation study of a priced managed lane on I-94. } \\
\hline Status & \multicolumn{4}{|c|}{ Study just started. } \\
\hline
\end{tabular}

\begin{tabular}{|c|c|c|c|c|}
\hline \multicolumn{5}{|c|}{ Florida Department of Transportation, FL - FY 2010} \\
\hline \multicolumn{2}{|c|}{ Project Type } & Value Pricing Pilot Program & Pricing Type & Grant \\
\hline \multicolumn{2}{|c|}{ Managed lanes } & & & $\$ 900,000$ \\
\hline Project & \multicolumn{4}{|c|}{$\begin{array}{l}\text { Initiative for a regional priced managed lane network that can serve as a model for other } \\
\text { regions. }\end{array}$} \\
\hline Status & \multicolumn{4}{|c|}{ Feasibility study is underway. } \\
\hline
\end{tabular}

\begin{tabular}{|c|c|c|c|c|}
\hline \multicolumn{5}{|c|}{ North Carolina Department of Transportation \& Charlotte MPO, NC - FY 2010} \\
\hline \multicolumn{2}{|c|}{ Project Type } & Value Pricing Pilot Program & Pricing Type & Grant \\
\hline \multicolumn{2}{|c|}{ Managed lanes } & Priced lanes & HOT & $\$ 400,000$ \\
\hline Project & \multicolumn{4}{|c|}{$\begin{array}{l}\text { Explore and advance pricing in the Charlotte region by evaluating the impacts of tolling } \\
\text { an interstate prior to and during construction of new infrastructure, and explore public } \\
\text { acceptance of multiple funding sources. }\end{array}$} \\
\hline Status & \multicolumn{4}{|c|}{ Feasibility study is underway (early 2012). } \\
\hline
\end{tabular}

\begin{tabular}{|c|c|c|c|c|}
\hline \multicolumn{5}{|c|}{ Tampa-Hillsborough Expressway Authority, FL - FY 2010} \\
\hline \multicolumn{2}{|c|}{ Project Type } & Value Pricing Pilot Program & Pricing Type & Grant \\
\hline \multicolumn{2}{|c|}{ Managed lanes } & Priced lanes & BTL & $\$ 800,000$ \\
\hline Project & \multicolumn{4}{|c|}{ Advance first regional network of bus toll lanes in the Tampa area. } \\
\hline Status & \multicolumn{4}{|c|}{ Feasibility study is underway. } \\
\hline
\end{tabular}

\begin{tabular}{|c|c|c|c|c|}
\hline \multicolumn{5}{|c|}{ California Department of Transportation, CA - FY 2011} \\
\hline \multicolumn{2}{|c|}{ Project Type } & Value Pricing Pilot Program & Pricing Type & Grant \\
\hline \multicolumn{2}{|c|}{ Managed lanes } & Zone-based pricing & Cordon/area pricing & $\$ 3,200,000$ \\
\hline Project & \multicolumn{4}{|c|}{$\begin{array}{l}\text { Evaluate the application of cordon and area pricing within major activity centers in the } \\
\text { downtown Los Angeles core, and build out a network of HOT lanes. }\end{array}$} \\
\hline Status & \multicolumn{4}{|c|}{ Project was approved for funding. } \\
\hline
\end{tabular}




\begin{tabular}{|c|c|c|c|c|}
\hline \multicolumn{5}{|c|}{ I-84 Viaduct - Connecticut Department of Transportation, CT - FY 2011} \\
\hline \multicolumn{2}{|c|}{ Project Type } & Value Pricing Pilot Program & Pricing Type & Grant \\
\hline \multicolumn{2}{|c|}{ Managed lanes } & Priced lanes & ETL & $\$ 644,000$ \\
\hline Project & \multicolumn{4}{|c|}{$\begin{array}{l}\text { Study the application of pricing on the I- } 84 \text { Viaduct, Hartford, CT, including an } \\
\text { assessment of the impacts of environmental justice issues that resulted from original } \\
\text { construction of the viaduct. }\end{array}$} \\
\hline Status & \multicolumn{4}{|c|}{$\begin{array}{l}\text { Project was approved for funding. FHWA awarded and allocated funds on February 6, } \\
2012 \text {. }\end{array}$} \\
\hline
\end{tabular}

\section{Dallas Area Rapid Transit, TX - FY 2011}

\begin{tabular}{l|l|l|l}
\hline Project Type & Value Pricing Pilot Program & Pricing Type & Grant \\
\hline Managed lanes & \multicolumn{2}{|l}{$\begin{array}{l}\$ 160,000 \\
\text { Project }\end{array}$} & $\begin{array}{l}\text { Study will look at a transit credit program designed to provide occasional free use of the } \\
\text { program at a park-and-ride lot with free parking and shuttle services added from a more } \\
\text { distant lot. }\end{array}$ \\
\hline Status & Approved for funding. & \\
\hline
\end{tabular}

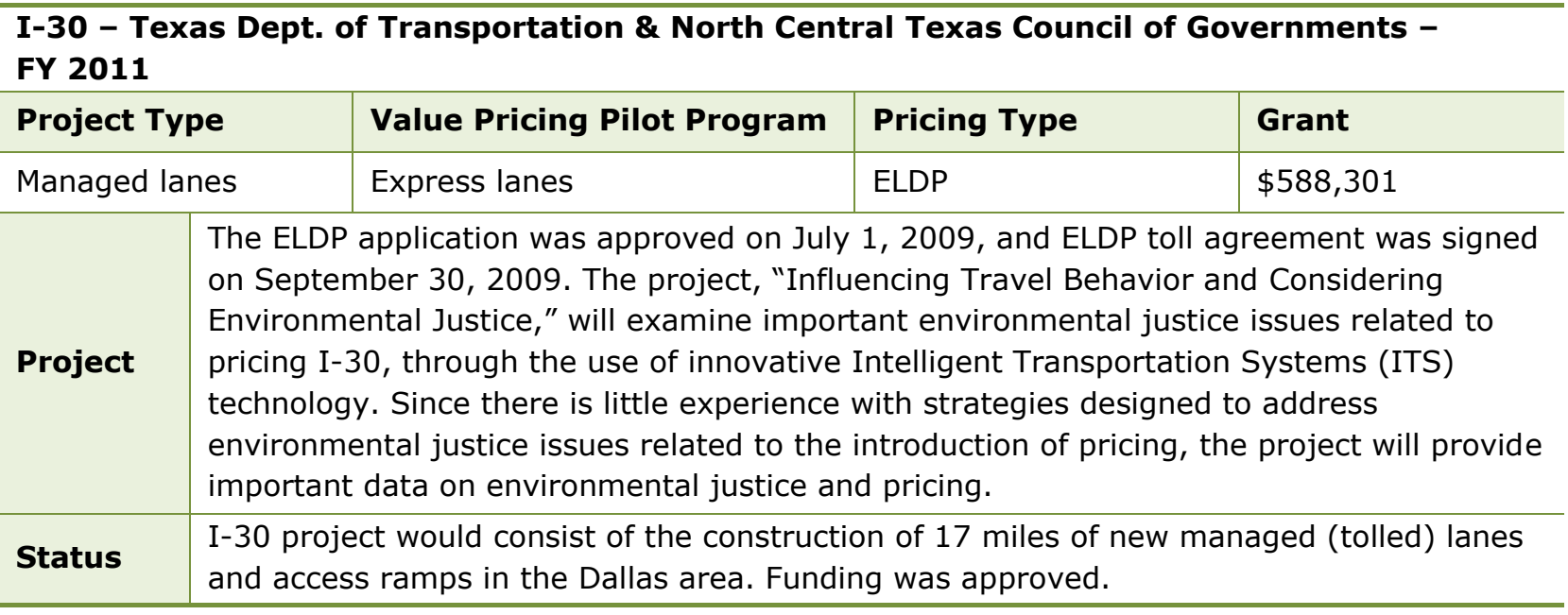

\begin{tabular}{|c|c|c|c|c|}
\hline \multicolumn{2}{|c|}{ Project Type } & Value Pricing Pilot Program & Pricing Type & Grant \\
\hline \multicolumn{2}{|c|}{ Managed lanes } & & & $\$ 1,220,424$ \\
\hline Project & \multicolumn{4}{|c|}{$\begin{array}{l}\text { 183A Turnpike Pilot implements a peak period toll in conjunction with dynamic } \\
\text { ridesharing on an existing congested toll road. Project explores dynamic ridesharing as } \\
\text { an equity mitigation strategy; a field trial is included as part of project. The road opens in } \\
2012 \text {. Local agencies are contributing funds to support the project; therefore, this project } \\
\text { meets the evaluation criteria for innovation, livability, sustainability, equity, congestion } \\
\text { reduction, safety, and state of good repair. }\end{array}$} \\
\hline Status & \multicolumn{4}{|c|}{ Project was approved for funding. } \\
\hline
\end{tabular}




\begin{tabular}{|c|c|c|c|c|}
\hline \multicolumn{5}{|c|}{ Virginia Department of Transportation \& Washington COG - FY 2011} \\
\hline \multicolumn{2}{|c|}{ Project Type } & Value Pricing Pilot Program & Pricing Type & Grant \\
\hline \multicolumn{2}{|c|}{ Managed lanes } & System-wide pricing & VPP regional network & $\$ 320,000$ \\
\hline Project & \multicolumn{4}{|c|}{ Advance regional pricing in DC, including pricing existing facilities. } \\
\hline Status & \multicolumn{4}{|c|}{ Feasibility study is underway. } \\
\hline \multicolumn{5}{|c|}{ I-805, San Diego, CA - FY 2012* } \\
\hline \multicolumn{2}{|c|}{ Project Type } & Value Pricing Pilot Program & Pricing Type & Grant \\
\hline \multicolumn{2}{|c|}{ Managed lanes } & & HOV & \\
\hline Project & \multicolumn{4}{|c|}{$\begin{array}{l}\text { SANDAG was awarded } \$ 100 \text { million by the California Transportation Commission (CTC) to } \\
\text { build two HOV lanes-one in each direction-on I- } 805 \text { between Palomar Street and SR } \\
94 \text {. Lanes will provide choices for drivers in South County, allowing carpoolers and transit } \\
\text { riders to access the HOV lanes and quickly travel back and forth to downtown San Diego. } \\
\text { The South Bay BRT project, a } 21 \text {-mile rapid, reliable, and high-frequency transit service, } \\
\text { is expected to be in service in early } 2014 \text {. In the long-term, the BRT will operate on HOV } \\
\text { lanes on SR } 94 \text { and along I- } 805 \text { managed lanes, with direct access ramps connecting } \\
\text { freeway stations and park-and-ride lots. }\end{array}$} \\
\hline Status & \multicolumn{4}{|c|}{$\begin{array}{l}\text { Project was approved for funding. FHWA awarded and allocated funds on February 6, } \\
2012 .\end{array}$} \\
\hline
\end{tabular}

*Discussed in detail in the report. 